\title{
TRANSPORT VAN X-VIRUS IN DE AARDAPPEL (SOLANUM TUBEROSUM L.) \\ BIJ PRIMAIRE INFECTIE
}

With a summary:

TRANSLOCATION OF VIRUS X IN THE POTATO

(SOLANUM TUBEROSUM $L$.)

IN PRIMARILY INFECTED PLANTS

\author{
Wibtietheok \\ der \\ Landbouw Hoogaschoe \\ WAGENINGEA
}

A. B. R. BEEMSTER

NN08201,247 
TRANSPORT VAN X-VIRUS IN DE AARDAPPEL (SOLANUM TUBEROSUM L.)

BIJ PRIMAIRE INFECTIE

With a summary:

TRANSLOCATION OF VIRUS X IN THE POTATO

(SOLANUM TUBEROSUM $L$.)

IN PRIMARILY INFECTED PLANTS

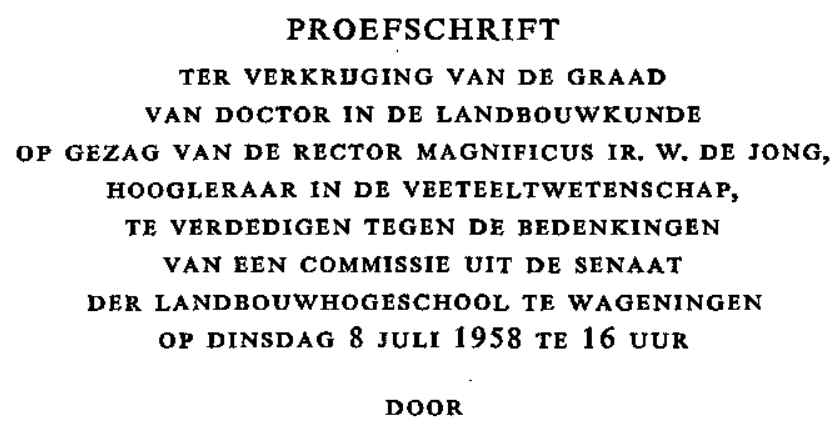

A. B. R. BEEMSTER

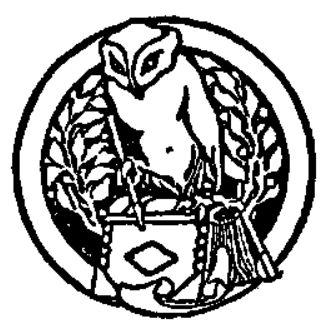

H. VEENMAN \& ZONEN - WAGENINGEN - 1958 


\section{STELLINGEN}

I

Het is niet mogelijk, na te gaan in. welke vorm plantevirussen in het floëem worden getransporteerd.

II

Uit de vorm van een virus, zoals deze zich met behulp van de elektronenmicroscoop aan ons voordoet, kunnen een aantal eigenschappen van het desbetreffende virus met vrij grote zekerheid worden voorspeld.

\section{III}

De algemeen gehuldigde opvatting, dat het bladrolvirus van aardappel in het floëem is gelokaliseerd, berust op onvoldoende gronden.

\section{IV}

In Nederland dient te worden gestreefd naar een grotere spreiding van de oogst van doperwten. Hiertoe verdient het gebruik van verschillende rassen de voorkeur boven het zaaien op verschillende tijdstippen.

\section{$\mathrm{V}$}

Bij het onderzoek naar de invloed van de daglengte op de produktie van cultuurgewassen moet onderscheid worden gemaakt tussen het fotosynthetisch en het eventueel fotoperiodisch effect.

\section{VI}

Uit de resultaten van de nacontrole van aardappelpootgoed met de IGELLANGE toets blijkt, dat de besmetting in het loof in hoofdzaak op een vroeg tijdstip plaats vindt.

\section{VII}

Het is gewenst, dat standaardmethoden worden opgesteld, die voor de beschrijving van virussen dienen te worden toegepast.

\section{VIII}

Toepassing van curatieve fungiciden verdient bij de bestrijding van verschillende schimmelziekten de voorkeur boven het gebruik van preventieve middelen.

IX

Het is onjuist, met betrekking tot het vaststellen van de rooidatum bij de teelt van aardappelpootgoed, rasverschillen in acht te nemen, die zijn gebaseerd op het tijdstip van afrijping van elk der betrokken rassen.

\section{$\mathrm{X}$}

Bij de overgang van agrarische bevolkingsgroepen naar de industrie treden spanningen op, die in een gerichte vrije-tijdsbesteding dienen te worden opgevangen. 


\section{VOORWOORD}

Bij de voltooiüng van dit proefschrift, wil ik allen, die hieraan op enigerlei wijze hebben medegewerkt, mijn erkentelijkheid betuigen.

Mijn dank gaat allereerst uit naar MIJN OUDERs, die zich voor de vorming hunner kinderen veel offers hebben moeten getroosten. Dat mijn VADER, die altijd zo veel belangstelling toonde voor mijn werk, geen getuige heeft moge zijn van het tot stand komen van dit proefschrift, betreur ik zeer.

Hooggeleerde THUNG, hooggeachte promotor, de wijze, waarmede U mij tegemoet bent getreden van de tijd af, dat ik als student op Uw afdeling heb mogen werken, heeft mij steeds getroffen. Voor het feit, dat ik in zo ruime mate heb mogen profiteren van Uw ervaring en inzichten en voor de hartelijke belangstelling, die $U$ en Mevrouw THung steeds hebben getoond voor mijn gezin, ben ik zeer erkentelijk.

Hooggeleerde WeLLENSIER, Uw heldere colleges en de logische en systematische wijze, waarop $U$ wetenschappelijke problemen tot een oplossing voert, hebben mijn grootste bewondering.

Hooggeleerde WASSINK, de tijd, die ik op Uw laboratorium doorbracht, is voor mij van groot nut geweest.

Beste VAN DER WANT, veel heb ik, vooral tijdens de eerste periode van mijn loopbaan als onderzoeker, van je mogen leren. De talloze gesprekken, die ik met je mocht voeren, leidden dikwijls tot nieuwe inzichten en ideeën. Voor de waardevolle opmerkingen bij de bewerking van het manuscript, dank ik je zeer.

Dat U, zeergeleerde TEN HouTEN, bij de veelheid van problemen, die U bezig houden, geregeld van $U w$ belangstelling voor mijn werk blijk geeft, waardeer ik zeer. Voor het feit, dat $U$ mij de gelegenheid hebt geboden het onderzoek tot een proefschrift te bewerken en het als I.P.O.-mededeling te laten verschijnen, ben ik U zeer dankbaar.

U, zeer geachte ROzENDAAL, dank ik voor het feit, dat ik nooit tevergeefs een beroep heb gedaan op Uw grote ervaring en inzicht betreffende de problemen der aardappelvirussen.

De goede sfeer, die op de virologische afdeling van het I.P.O. heerst, schept de voorwaarden, die voor het verrichten van vruchtbaar onderzoek onontbeerlijk zijn. $\mathrm{U}$, leden van deze afdeling, die hier allen toe bijdraagt, betuig ik hiervoor mijn dank.

De andere collega's van het I.P.O. dank ik voor de vriendschap, die ik steeds heb mogen ondervinden.

Voor de grote ijver en toewijding, waarmede U, Mevr. J. VAN DEN BROEKBLOM de eerste periode en Mej. TAN TIAN Nro de laatste jaren, assistentie hebt verleend bij de uitvoering van de proeven, ben ik veel dank verschuldigd.

Het personeel van tuin en kassen, bij wie de zorg over de planten steeds in goede handen was en het technisch en administratief personeel van het I.P.O., die, op welke wijze ook, hulp hebben verleend, dank ik daarvoor hartelijk. 


\section{INHOUD}

Algemene Inleiding . . . . . . . . . . . . . . . 3

HoofDSTUK 1. Het transport van aardappel X-virus van het geïnoculeerde blad naar de stengel . . . . . . . . . . 5

1.1. Inleiding. . . . . . . . . . . 5

1.2. Literatuur . . . . . . . . . . . . 5

1.3. Eigen onderzoek . . . . . . . . . . . . . 6

1.3.1. Materiaal en methoden . . . . . . . . 6

1.3.2. Proeven met tabak als proefplant . . . . . 7

1.3.3. Proeven met Physalis fioridana als toetsplant . 9

1.3.4. Proeven met aardappel als toetsplant . . . . 11

1.4. Bespreking van de resultaten . . . . . . . . 13

HoordSTUK 2. Het transport van aardappel X-virus door de stengel van de aardappelplant . . . . . . . . . . 15

2.1. Inleiding. . . . . . . . . . . 15

2.2. Literatuur . . . . . . . . . . . 15

2.3. Eigen onderzoek . . . . . . . . . . . 17

2.3.1. Materiaal en methoden ........ 17

2.3.2. Het transport door de stengel bepaald volgens de stekmethode . . . . . . . . . 17

2.3.3. Het transport door de stengel bepaald door directe toetsing op toetsplanten ..... 20

2.3.4. Het transport van blad naar blad . . . . . . 23

2.4. Bespreking van de resultaten . . . . . . . . 25

HoofDSTuK 3. Het transport van aardappel X-virus van het geïnoculeerde blad naar de knollen. . . . . . . . . . . . . . . 27

3.1. Inleiding. . . . . . . . . . . . . 27

3.2. Literatuur . . . . . . . . . . . . . 27

3.3. Eigen onderzoek . . . . . . . . . . . . . . 28

3.3.1. Materiaal en methoden . . . . . . . . . 28

3.3.2. Verwerking van de gegevens ...... . . 28

3.3.3. Onderzoek met het ras Bintje in de kas . . . 29

3.3.4. Onderzoek met het ras Bintje in het veld . . . 31

3.3.5. Onderzoek met verschillende rassen in de kas . 34

3.3.6. Onderzoek met verschillende rassen in het veld 38

3.4. Samenvatting en bespreking van de resultaten . . . 40 
HoofDSTUK 4. Nader onderzoek over de ouderdomsresistentie . . . . . 43

4.1. Inleiding en literatuur . . . . . . . . . . . 43

4.2. De ouderdomsresistentie en het verband met het ontwikkelingsstadium van de aardappelplant . . . . . 45

4.3. De ouderdomsresistentie en het verband met de virusvermeerdering in het geïnoculeerde blad . . . . . 48

4.4. Algemene bespreking van de resultaten ....... 54 .

HoOFDSTUK 5. Enkele bijzondere aspecten van de besmetting van de knollen ................... . . 59

5.1. Inleiding. . . . . . . . . . . . . . 59

5.2. Het verband tussen knolgrootte en virusbesmetting . 59

5.3. De plaats van het aardappel $\mathrm{X}$-virus in primair geinfecteerde knollen ........... . 63

5.4. Wat gebeurt er met het virus tijdens de bewaring en na het poten van de knol? . . . . . . . . 63

5.5. Bespreking van de resultaten . . . . . . . . 66

HoofDSTUK 6. Algemene nabeschouwing . . . . . . . . . . 67

6.1. Enkele beschouwingen over praktische problemen . . 67

6.2. Enkele theoretische beschouwingen . . . . . . 68

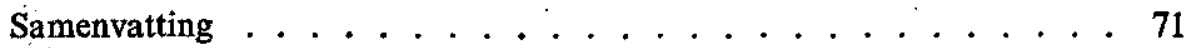

Summary . . . . . . . . . . . . . 73

Literatuur ... . . . . . . . . . . . . . 82

Aanhangsel $\ldots \ldots \ldots \ldots \ldots$ 


\section{ALGEMENE INLEIDING}

Het telen van pootaardappelen van hoge kwaliteit, wat vooral wil zeggen: vrij van virusziekten, kan in Nederland met succes plaats hebben dank zij de vrij gunstige klimatologische omstandigheden. Deze omstandigheden bepalen nl. het tijdstip van het optreden van Myzus persicae (Sulz.), die als de belangrijkste overbrenger van een aantal aardappelvirussen beschouwd kan worden. Dit tijdstip nu is in Nederland zodanig, dat de besmetting van de planten zo laat plaats vindt, dat deze kunnen worden gerooid, voordat het virus de knollen heeft bereikt. Toch zijn de omstandigheden geenszins zodanig, dat zonder verdere maatregelen gezond pootgoed zou kunnen worden geteeld. Een nauwkeurig uitgevoerd stelsel van cultuurmaatregelen is hier onontbeerlijk. Deze maatregelen zijn gebaseerd op de mogelijkheid om de kans op infectie van de jonge knollen te verminderen door b.v. de infectiebronnen weg te nemen (vroege selectie) en indien al een infectie in het blad tot stand is gekomen, zodanige maatregelen te treffen, dat het virus niet in de voor pootgoed bestemde knollen komt. Om dit laatste te bereiken wordt elk jaar een datum (,rooidatum”) vastgesteld, vóór welke de planten moeten zijn gerooid. Voor de juiste vaststelling van deze datum zijn de volgende punten van belang: 1e. Het tijdstip van infectie van de plant. 2e. Het tijdsverloop tussen de infectie van de plant en het moment, waarop het virus de knol binnendringt. Het eerstgenoemde punt is voor een belangrijk deel een entomologische kwestie, althans voor wat betreft de virussen, die door bladluizen worden overgebracht. Dit zijn voor Nederland voornamelijk het bladrol-, Y-, A- en aucubabontvirus, waarvan bladrol wel het belangrijkste genoemd mag worden. Omtrent het tweede punt, nl. de vraag hoe lang het duurt voordat het virus na een infectie van het loof, de knollen bereikt, waren tot dusverre nog onvoldoende gegevens bekend. Dat echter een juist inzicht hierin van groot belang is, moge blijken uit het volgende. Een te vroeg rooien van de planten zou voor de kwaliteit van het pootgoed gunstig zijn, maar zou in vele gevallen aanleiding geven tot te kleine opbrengsten. In een artikel, voorkomend in de ,,Verslagen van het Landbouwkundig Onderzoek in de NoordOost Polder" (ANONYMUs, 1955) worden cijfers genoemd over de knolgroei van

TABEL 1. Mate, waarin de knollen van enkele aardappelrassen in gewicht (uitgedrukt in $\mathrm{kg} / \mathrm{ha} / \mathrm{dag}$ ) toenemen in de periode van 10 dagen vó́r tot vijf dagen na de datum van het vroege rooien.

Rate of daily growth of the tubers of some potato varieties in $\mathrm{kg} / \mathrm{ha}$ in the period from ten days before till five days after the date of early harvesting.

\begin{tabular}{c|c|c|c|c}
\hline Ras / Variety & 1953 & 1954 & 1955 & $\begin{array}{c}\text { gemiddeld / } \\
\text { average } \\
1953 / 1955\end{array}$ \\
\hline Bintje . . . & 810 & 950 & 890 & 880 \\
Eigenheimer . . & 830 & 760 & 700 & 760 \\
IJsselster . . . & 650 & 710 & 680 & 680 \\
Voran . . . . & 810 & 470 & 640 & 640 \\
Alpha ..... & 760 & 670 & 640 & 690
\end{tabular}


enkele aardappelrassen omstreeks de rooidatum (van de klasse E), waaruit de in tabel 1 vermelde cijfers zijn overgenomen.

We zien hieruit, dat omstreeks de rooidatum nog een zeer sterke knolgroei plaats heeft en te vroeg rooien zou dan ook financiëel nadelig zijn voor de pootaardappeltelers. Te laat rooien daarentegen zou aanleiding geven tot een hoog percentage viruszieke knollen, daar het virus in dat geval de gelegenheid zou hebben in de jonge knollen door te dringen. Het belang van juiste gegevens omtrent de snelheid van het virustransport naar de knollen is dus duidelijk.

Gedurende een aantal jaren werden daarom proefnemingen aangaande het transport yan aardappel X-, Y-, S- en bladrolvirus verricht. Het onderzoek, betrekking hebbend op het aardappel $\mathrm{X}$-virus zullen in dit geschrift worden vermeld, waarbij verschillende aspecten van het virustransport ter sprake komen. 


\section{HET TRANSPORT VAN AARDAPPEL X-VIRUS VAN HET GEINOCULEERDE BLAD NAAR DE STENGEL}

\subsection{INLEIDING}

Bij de bestudering van het transport van virussen van het moment van de inoculatie op een bepaalde plaats tot op het moment, waarop het virus in een ander gedeelte van de plant kan worden aangetoond, moeten, zoals o.a. reeds door CAPOOR (1949) werd vastgesteld, de volgende fasen worden onderscheiden. 1. De vermeerdering van het virus op de plaats, waar de inoculatie tot stand is gekomen.

2. Het transport van het virus van dit ,vermeerderingscentrum" af naar de overige delen van de plant.

3. De vermeerdering van het virus op de plaats, waar het na het transport is aangekomen.

Punt 3 is in feite slechts voor het experiment van betekenis. Uit het oogpunt van snelheid van virustransport doet het niet ter zake. Is het virus nl. eenmaal ergens aangekomen, dan zal het pas na een bepaalde tijd aanleiding geven tot het verschijnen van ziektesymptomen of met andere hulpmiddelen zijn aan te tonen. Bij de bestudering van het virustransport moet men echter wel degelijk rekening houden met de genoemde derde fase, omdat de methoden van virusdiagnostiek, die ons ter beschikking staan, niet zo gevoelig zijn, dat één of enkele (pas getransporteerde) virusdeeltjes kunnen worden aangetoond. We zouden dus, afgaande op de resultaten, verkregen met de gebruikelijke toetsmethoden steeds een verkeerd beeld van het transport van het virus krijgen. We moeten daarom bij de opzet van onze proeven steeds rekening met deze factor houden.

\subsection{LITERATUUR}

Het transport van virussen in het algemeen is reeds door vele onderzoekers onderzocht en beschreven. Duidelijk komt uit het onderzoek hierover naar voren, dat een zekere periode moet zijn voorbijgegaan, alvorens een verplaatsing van het virus van enige betekenis is aan te tonen. BöNING (1928) vond, door na de inoculatie periodiek de geïnoculeerde bladeren weg te nemen, dat T.M.V. ${ }^{1}$ ) in tomaat na drie dagen de stengel was binnengetreden. SAMUEL (1934) verkreeg met hetzelfde virus en dezelfde proefplant dezelfde resultaten, terwijl KUNKEL (1939) ook met T.M.V. en tomaat een minimum tijd vond van 44 uren. Beide laatstgenoemde onderzoekers pasten een werkwijze toe, waarbij de aanwezigheid van het virus op een bepaald moment werd vastgelegd door b.v. een stengeldeel gedurende enige tijd in steriele, vochtige buizen te leggen. Nadat op deze wijze eventueel aanwezig virus de gelegenheid had gehad om tot vermeerdering te komen, werd de aanwezigheid ervan nagegaan op een toets-

1) Tabaksmozaīekvirus 
plant. Hoewel de mogelijkheid bestaat, dat op deze wijze niet in alle gevallen een juist beeld werd verkregen, wijken de resultaten niet merkbaar af van die, welke op andere wijzen werden verkregen. PANOs (1948), werkend met T.M.V. en aardappel X-virus, beide met tomaat als proefplant, vond voor het T.M.V. een tijd van minimaal vier dagen, voor het aardappel $X$-virus vijf dagen. Deze tijden liggen iets hoger dan vorengenoemde, wat waarschijnlijk moet worden toegeschreven aan het feit, dat PANOS een serologische toetsmethode gebruikte, die niet gevoelig genoeg is om ook geringe virusconcentraties aan te tonen. CAPOor (1949) paste dezelfde werkwijze toe als SAMUEL en vond voor T.M.V. in tomaat drie en een halve dag en voor het aardappel $\mathrm{X}$-virus, eveneens in tomaat, drie dagen.

Met aardappel als toetsplant werd gewerkt door ZYLSTRA (1941), die vermeldt, dat het ,Canada streak" - virus en het ,,rugose mosaic" - virus 72 uur nodig hebben om uit het geïnoculeerde blad in de bladsteel en 94 uur om uit het blad in de stengel te komen.

De bovenvermelde gegevens hadden alle betrekking op met sap over te brengen virussen. Minder talrijk zijn de gegevens over uitsluitend door insekten over te brengen virussen. BENNETT (1934) werkte met het ,curly top"-virus van biet en vond, dat dit virus reeds een uur later het door middel van de cicadellide Eutettix tenellus (thans: Circulifer tenellus) geinoculeerde blad van de biet had verlaten. Voor een virus van mais, het zgn. „mais streak"-virus, vond STOREY (1928), dat gedurende de eerste twee uren na de inoculatie een verplaatsing van $40 \mathrm{~cm}$ in het blad plaats vond. BEEMSTER (in druk) vond voor het bladrolvirus van aardappel met als toetsplant Physalis floridana dat dit virus in de meeste gevallen minstens 24 uur in het geinoculeerde blad blijft. $\mathrm{Na} 42$ uur is het meestal de stengel binnengetreden.

Uit de gegevens over de met sap over te brengen virussen blijkt, dat het moment, waarop zulk een virus het geïnoculeerde blad verlaat niet geheel hetzelfde is bij de verschillende auteurs. Deze wijzen er overigens ook in hun publikaties op, dat verschillen tussen verschillende planten van een proefserie steeds worden gevonden. De orde van grootte echter wijkt duidelijk af van die, welke werd gevonden voor de door cicadelliden overgebrachte virussen van biet en mais.

\subsection{EIGEN ONDERZOEK}

\subsubsection{Materiaal en methoden}

Hoewel BöNING (1928) reeds een methode toepaste; die zeer betrouwbare resultaten geeft, hebben de meeste andere auteurs werkwijzen gebruikt, waartegen in bepaalde opzichten bezwaren zijn aan te voeren. Dit geldt met name voor de wijze, waarop de aanwezigheid van het desbetreffende virus werd aangetoond. Het is nl. zeer onwaarschijnlijk, dat de geringe virusconcentratie, die in de eerste periode na de inoculatie in de stengel aanwezig is, met behulp van de serologie of van toetsplanten kan worden aangetoond.

In de door ons uitgevoerde proeven werd het tijdstip van het uittreden van het aardappel X-virus uit het geïnoculeerde blad nagegaan bij tabak, Physalis floridana en aardappel. Bij tabak werd tevens de mogelijkheid van diagnose met behulp van toetsplanten en met behulp van een antiserum vergeleken met de werkelijke aanwezigheid van het virus, door in een groeiende plant het pas ge- 
transporteerde virus tot vermeerdering te laten komen. In al deze proeven werd gewerkt met een stam van het aardappel X-virus; ons verstrekt door Ir. A. ROZENDAAL en door hem gekenschetst als een sterke stam van het $X$-virus. Steeds werd het tabaksras White Burley gebruikt, waarvan wij voor iedere proefreeks zo uniform mogelijke planten uitzochten, die werden geïnoculeerd in het stadium, dat zich twee tot drie bladeren volkomen hadden ontwikkeld. Ook in de proeven met Physalis floridana werden altijd uniforme toetsplanten gebruikt. Deze proefplanten werden geïnoculeerd op het vierde blad, op het moment, waarop dit blad volkomen was ontwikkeld. De inoculatie geschiedde met sap en carborundumpoeder. De proeven werden uitgevoerd in luisvrije ruimten bij een dagtemperatuur van $22-24^{\circ} \mathrm{C}$. De gebruikte aardappelplanten waren eenstengelig en in potten opgekweekt. De stadia, waarin deze planten werden gebruikt, waren niet gelijk in de verschillende proeven.

Het algemene principe van de proeven was, dat op gezette tijden de geïnoculeerde bladeren werden afgeknipt. Door de planten hierna te laten doorgroeien en dan na te gaan, welke planten symptomen vertoonden, kon worden vastgesteld op welk moment het virus uit het geïnoculeerde blad in de stengel was doorgedrongen.

\subsubsection{Proeven met tabak als proefplant}

Op 7 november 1953 werden 50 tabaksplanten op een jong, volgroeid blad geïnoculeerd. Het geïnoculeerde blad van telkens 15 planten werd twee, drie, vier, vijf, zes en zeven dagen na de inoculatie afgeknipt, waarbij door ontsmetting van de schaar werd voorkomen, dat het virus door deze behandeling op niet gewenste wijze werd overgebracht. Van deze 15 planten bleven er vijf staan om te zien op welk moment het virus uit het geïnoculeerde blad was getransporteerd. Vijf andere planten werden op het moment, waarop het geïnoculeerde blad werd afgeknipt, getoetst met Gomphrena globosa, terwijl de vijf nog resterende planten, eveneens na het afknippen van het geïnoculeerde blad, serologisch werden getoetst volgens de agglutinatiemethode.

De agglutinatiemethode wordt uitgevoerd met een druppel ruw perssap en vereist dus geen tijdrovende centrifugebehandelingen, waardoor deze methode zeer aantrekkelijk is om grote aantallen monsters te toetsen. Zoals echter uit tabel 2 (serie 1) blijkt, is de methode niet erg gevoelig. We zien nl. dat, terwijl het virus in deze proef reeds bij drie van de vijf planten na twee dagen het geinoculeerde blad had verlaten, het zeven dagen na de inoculatie nog niet serologisch in de planten kon worden aangetoond. Met behulp van G.globosa was dit reeds op de vierde dag na de inoculatie mogelijk. Bij het bezien van deze en de volgende resultaten moeten we wel bedenken, dat door het uitpersen van de gehele plant het eventueel aanwezige virus sterk wordt verdund.

In een tweede proef, waarvan de resultaten eveneens zijn weergegeven in tabel 2 (serie 2), werd reeds 24 uur na de inoculatie begonnen met van 15 planten het geïnoculeerde blad af te knippen. De proef werd overigens vrijwel op dezelfde wijze uitgevoerd als de eerstbeschrevene met alleen nog dit verschil, dat thans bij de serologische toetsing de precipitatiemethode, waarbij met gecentrifugeerd sap wordt gewerkt, werd toegepast. Uit de resultaten kan worden opgemaakt, dat in deze proef het virus op de vierde dag na de inoculatie uit het geînoculeerde blad was getreden. Het virus kon twee dagen later met G.globosa worden aangetoond en drie dagen later werd serologisch een positieve reactie 
verkregen. Naast het verschil in tijdstip van het uittreden van het virus uit het geïnoculeerde blad tussen de twee proeven, is duidelijk te zien, dat de precipitatiereactie gevoeliger is dan de agglutinatiereactie en bovendien, dat de methode met behulp van toetsplanten de beste is.

TABEL 2. De waarde van de toets op Gomphrena globosa en van serologische methoden voor de vaststelling van het tijdstip, waarop aardappel $\mathrm{X}$-virus uit het geinoculeerde blad van het tabaksras White Burley wordt gevoerd.

The value of the test on Gomphrena globosa and of serological methods to determine the interval between the inoculation of the leaf and entering the stem of potato virus $X$ in White Burley tobacco.

\begin{tabular}{|c|c|c|c|c|}
\hline \multirow[t]{2}{*}{$\begin{array}{l}\text { Serie } \\
\text { Series }\end{array}$} & \multirow{2}{*}{$\begin{array}{l}\text { Aantal dagen tussen inocu- } \\
\text { latie en afknippen van het } \\
\text { geinoculeerde blad } \\
\text { Number of days between inocu- } \\
\text { lation and removal of the } \\
\text { inoculated leaf }\end{array}$} & \multirow{2}{*}{$\begin{array}{l}\text { Aantal geinfecteerde } \\
\text { planten } \\
\text { Number of infected } \\
\text { olants }\end{array}$} & \multicolumn{2}{|c|}{$\begin{array}{l}\text { Toetsing van de planten zonder het geinocu- } \\
\text { leerde blad op de dag van het afknippen } \\
\text { Testing of the plants writhout the inoculated leaf } \\
\text { on the day of removing the leaf }\end{array}$} \\
\hline & & & $\begin{array}{l}\text { met/with } \\
\text { G.globosa }\end{array}$ & $\begin{array}{l}\text { serologisch') } \\
\text { serologically }{ }^{1} \text { ) }\end{array}$ \\
\hline 1 & $\begin{array}{r}2 \\
3 \\
4 \\
5 \\
6 \\
7\end{array}$ & $\begin{array}{l}\left.3 / 5^{2}\right) \\
5 / 5 \\
5 / 5 \\
5 / 5 \\
5 / 5 \\
5 / 5\end{array}$ & $\begin{array}{l}0 / 5 \\
0 / 5 \\
2 / 5 \\
5 / 5 \\
5 / 5 \\
5 / 5\end{array}$ & $\begin{array}{l}0 / 5 \\
0 / 5 \\
0 / 5 \\
0 / 5 \\
0 / 5 \\
0 / 5\end{array}$ \\
\hline 2 & $\begin{array}{r}1 \\
2 \\
3 \\
4 \\
5 \\
7 \\
6 \\
8 \\
9\end{array}$ & $\begin{array}{l}0 / 5 \\
0 / 5 \\
0 / 5 \\
5 / 5 \\
5 / 5\end{array}$ & $\begin{array}{l}0 / 5 \\
0 / 5 \\
0 / 5 \\
0 / 5 \\
0 / 5 \\
1 / 5\end{array}$ & $\begin{array}{l}0 / 5 \\
0 / 5 \\
0 / 5 \\
0 / 5 \\
0 / 5 \\
0 / 5 \\
4 / 5 \\
3 / 5 \\
3 / 5\end{array}$ \\
\hline
\end{tabular}

1) Serie 1 volgens de agglutinatiereactie. Series 1 tested with the agglutinin reaction.

Serie 2 volgens de precipitatiereactie. Series 2 with the precipitin reaction.

2) Teller: aantal planten met symptomen; noemer: aantal toetsplanten.

Numerator: number of plants showing symptoms; denominator: number of test plants.

In een derde proef, die voor een deel op dezelfde wijze werd uitgevoerd als de beide eerstgenoemde proeven, werd G.globosa niet meer in de proef opgenomen. Er werd nagegaan wanneer het virus serologisch (met de precipitatiereactie) in het geïnoculeerde blad kon worden aangetoond en wat het effect was als het geïnoculeerde blad te zamen met de rest van de plant werd uitgeperst, hetgeen de virusconcentratie in het perssap dus verkleint. De resultaten van deze proef zijn samengevat in tabel 3 . Er blijkt uit, dat in deze proef op de zevende dag na de inoculatie, dat is vier tot vijf dagen na het werkelijke uittreden uit het geinnoculeerde blad, de serologische diagnose van het virus mogelijk was. Hierbij moet worden opgemerkt, dat op dat moment alle planten reeds ziektesymptomen in de topbladeren vertoonden. Verder zien we uit tabel 3, dat het virus in het geỉnoculeerde blad zelf zeer snel (na één dag al in drie van de vijjf bladeren) kon worden aangetoond. De concentratie van het virus bereikt spoedig een dusdánige hoogte, dat ook de verdunning met het nog niet geïnfecteerde deel van de plant geen invloed van betekenis meer kan uitoefenen, zoals blijkt uit de laatste kolom van tabel 3. 
TABEL 3. De waarde van de serologische precipitatiereactie voor de vaststelling van het tijdstip, waarop aardappel X-virus uit het geïnoculeerde blad van het tabaksras White Burley wordt gevoerd.

The value of the serological precipitin reaction to determine the interval between the inoculation of the leaf and entering the stem of potato virus $X$ in White Burley tobacco.

\begin{tabular}{|c|c|c|c|c|}
\hline \multirow{4}{*}{$\begin{array}{c}\text { Aantal dagen tussen inocu- } \\
\text { latie en arknippen van het } \\
\text { geinoculeerde blad } \\
\text { Interval between inoculation and } \\
\text { removal of the inoculated leaf } \\
\text { (days) }\end{array}$} & \multirow{4}{*}{$\begin{array}{c}\text { Aantal geinfecteerde } \\
\text { planten } \\
\text { Number of infected } \\
\text { planis }\end{array}$} & \multicolumn{3}{|c|}{$\begin{array}{l}\text { Serologische toetsjing } \\
\text { Serological testing }\end{array}$} \\
\hline & & \multirow{3}{*}{$\begin{array}{l}\text { van het afgeknipte } \\
\text { blad } \\
\text { of the removed leaf }\end{array}$} & \multicolumn{2}{|c|}{$\begin{array}{l}\text { van de gehele plant } \\
\text { of the whole plant }\end{array}$} \\
\hline & & & $\begin{array}{l}\text { zonder } \\
\text { without }\end{array}$ & $\begin{array}{l}\text { met } \\
\text { with }\end{array}$ \\
\hline & & & \multicolumn{2}{|c|}{$\begin{array}{c}\text { geinoculeerde blad } \\
\text { inoculated leaf }\end{array}$} \\
\hline $\begin{array}{r}1 \\
2 \\
3 \\
5 \\
6 \\
7 \\
8 \\
9 \\
10\end{array}$ & $\begin{array}{l}\left.0 / 10^{1}\right) \\
1 / 10 \\
6 / 10\end{array}$ & $\begin{array}{l}3 / 5 \\
5 / 5 \\
5 / 5 \\
5 / 5 \\
5 / 5 \\
5 / 5 \\
5 / 5 \\
5 / 5 \\
5 / 5\end{array}$ & $\begin{array}{l}0 / 5 \\
0 / 5 \\
0 / 5 \\
0 / 5 \\
2 / 5 \\
3 / 5 \\
5 / 5 \\
5 / 5\end{array}$ & $\begin{array}{l}1 / 5 \\
4 / 5 \\
5 / 5 \\
5 / 5 \\
5 / 5 \\
5 / 5 \\
5 / 5\end{array}$ \\
\hline
\end{tabular}

) Teller: aantal planten met symptomen; noemer: aantal toetsplanten.

Numerator: number of plants showing symptoms; denominator: number of test plants.

Samenvattende kunnen we zeggen, dat het aardappel $\mathrm{X}$-virus na ongeveer 48 uur het geïnoculeerde blad van tabak verlaat. De verschillen, die we tussen de in tabellen 2 en 3 weergegeven proefseries zagen, komen ook tot uiting bij vergelijking van de individuele planten in iedere proef. De toetsmethode met G.globosa, die te verkiezen is boven de serologische methoden is toch niet gevoelig genoeg om de kleine hoeveelheden virus aan te tonen waar het bij het transport in de plant blijkbaar om gaat. Om bij proeven aangaande het transport van virus met de grootst mogelijke betrouwbaarheid te werken, moet dus, indien mogelijk, het virus in de gelegenheid zijn in planteweefsels tot vermeerdering te komen. Zoals nog nader zal blijken, zijn er verschillende mogelijkheden om aan deze voorwaarde te kunnen voldoen.

\subsubsection{Proeven met Physalis floridana als toetsplant}

Physalis floridana vertoont ongeveer 10 dagen na de inoculatie met aardappel $\mathrm{X}$-virus duidelijk mozaileksymptomen in de topbladeren. Daar deze plant betrekkelijk klein is en er vrij snel uniforme toetsplanten van kunnen worden gekweekt, was het aantrekkelijk om ook hiermee enkele proeven uit te voeren, waarvan hier de resultaten zullen worden vermeld.

Op 7 augustus 1956 werd een proef uitgevoerd om het moment van het uittreden van het virus uit het geïnoculeerde blad na te gaan. De proef, waarvan de resultaten in tabel 4 zijn weergegeven, werd op dezelfde wijze uitgevoerd als de reeds beschreven proeven met tabak als toetsplant.

Uit tabel 4 is op te maken, dat het virus in $P$. floridana tussen het $42 \mathrm{e}$ en het 48e uur na de inoculatie het geinnoculeerde blad verlaat. De hier beschreven proef mag representatief worden geacht voor een groot aantal hierover uitgevoerde proeven. In deze proeven werd nooit voor het $40 \mathrm{e}$ uur, doch wel meestal na 48 uur, transport uit het geïnoculeerde blad waargenomen. 
TABEL 4. Het tijdstip, waarop het aardappel X-virus uit het geinoculeerde blad van Physalis floridana wordt gevoerd.

The interval between inoculation of leaves and entering the stem of potato virus $X$ in Physalis foridana.

\begin{tabular}{l|c|c|c|c|c|c|c|c}
\hline $\begin{array}{l}\text { Blad afgeknipt na (uren).... } \\
\text { Leaf removed after (hours) } \\
\text { Resultaat / Result ..... }\end{array}$ & 40 & $41 \frac{1}{2}$ & 43 & $44 \frac{1}{2}$ & 46 & $47 \frac{1}{2}$ & 64 & $65 \frac{1}{2}$ \\
\hline
\end{tabular}

1) Teller: aantal zieke planten; noemer: aantal toetsplanten.

Numerator: number of diseased plants; denominator: number of test plants.

Bij de beschouwing van de resultaten dringt zich de vraag op, in hoeverre de concentratie van het virus bij de inoculatie van invloed is op de gegeven tijden. Hierover werd de volgende proef uitgevoerd. Op 7 februari 1956 werden 100 $P$. floridana-planten in vier groepen van 25 planten verdeeld. Deze vier groepen werden respectievelijk geinoculeerd met aardappel $\mathrm{X}$-virus in de volgende con-

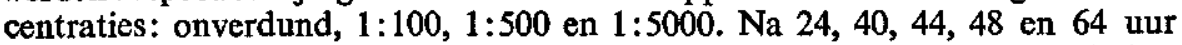
werd van telkens vijf planten van elke groep het geïnoculeerde blad afgeknipt. De resultaten zijn gegeven in tabel 5.

TABEL 5. Het tijdstip, waarop het aardappel X-virus uit het geinnoculeerde blad van Physalis foridana wordt gevoerd na inoculatie met verschillende virusconcentraties.

The interval between inoculation and entering the stem of potato virus $X$ in Physalis floridana after inoculation with different virus concentrations.

\begin{tabular}{c|c|c|c|c}
\hline $\begin{array}{c}\text { Geinoculeerde blad } \\
\text { afgeknipt na (uren) } \\
\text { Inoculated leaf removed } \\
\text { after (hours) }\end{array}$ & \multicolumn{4}{|c}{$\begin{array}{c}\text { Resultaten met de concentratie } \\
\text { Results with the concentration }\end{array}$} \\
\cline { 2 - 5 } & $\begin{array}{c}\text { onverdund } \\
\text { undiluted }\end{array}$ & $1: 100$ & $1: 500$ & $1: 5000$ \\
\hline & $0 / 51)$ & $0 / 5$ & $0 / 5$ & $0 / 5$ \\
24 & $5 / 5$ & $5 / 5$ & $1 / 5$ & $0 / 5$ \\
40 & $5 / 5$ & $5 / 5$ & $4 / 5$ & $4 / 5$ \\
44 & $5 / 5$ & $5 / 5$ & $5 / 5$ & $5 / 5$ \\
48 & $5 / 5$ & $5 / 5$ & $5 / 5$ & $5 / 5$ \\
64 & &
\end{tabular}

1) Teller: aantal zieke planten; noemer: aantal toetsplanten.

Numerator: number of diseased plants; denominator: number of test plants.

We zien, dat bij alle verdunningen het virus het geïnoculeerde blad na 44 uur heeft verlaten, bij onverdund en de concentratie 1:100 ook reeds na 40 uur. Hoewel bij sterker verdunning het virus dus blijkbaar iets later uit het geinoculeerde blad wordt gevoerd, mag het verschil niet van essentiële betekenis worden genoemd. Herhaalde proeven hierover gaven alle soortgelijke resultaten.

Om de vraag te kunnen beantwoorden in welke concentratie het virus in het geïnoculeerde blad aanwezig is op het moment, dat dit uit het geïnoculeerde blad wordt gevoerd, werden ook hierover enkele proeven uitgevoerd, waarvan hier een enkele wordt beschreven. Op 3 juli 1956 werd een aantal P. floridanaplanten op twee bladeren geinoculeerd. Op bepaalde tijden na de inoculatie (aangegeven in tabel 6) werden telkens vijf bladeren afgeknipt, te zamen uitgeperst en het verkregen perssap daarna uitgewreven op vijf bladeren van Gomphrena globosa. De tegenoverstaande bladeren werden op dezelfde tijd geinoculeerd met een standaard concentratie van het virus, die bewaard werd bij $0^{\circ} \mathrm{C}$. Door het aantal necrotische vlekken op de Gomphrena-bladeren te tellen, 
werd zo een indruk verkregen van de toeneming van de virusconcentratie in het geïnoculeerde blad. De resultaten zijn weergegeven in tabel 6 . Het blijkt, dat het virus omstreeks 40 uur na de inoculatie in het geĭnoculeerde blad kan worden aangetoond, zij het ook, dat slechts enkele vlekken werden geteld. Dit is dus ongeveer hetzelfde tijdstip, waarop het virus het geinnoculeerde blad van $P$. floridana verlaat. Na dit tijdstip zien we een geleidelijke stijging van de concentratie, die waarschijnlijk na 88 uur het maximum nog niet heeft bereikt.

TABEL 6. De concentratie van aardappel X-virus in de gelnoculeerde bladeren van Physalis foridana op verschillende tijdstippen na de inoculatie.

The concentration of potato virus $X$ in the inoculated leaves of Physalis floridana at different intervals after inoculation.

\begin{tabular}{c|c|c|c}
\hline \multirow{2}{*}{$\begin{array}{c}\text { Aantal uren na inoculatie } \\
\text { Number of hours after } \\
\text { inoculation }\end{array}$} & \multicolumn{3}{|c}{$\begin{array}{c}\text { Aantal vlekken op G.globosa } \\
\text { Number of lesions on G.globosa }\end{array}$} \\
\cline { 2 - 4 } & $\begin{array}{c}\text { Standaard } \\
\text { Standard }\end{array}$ & $\begin{array}{c}\text { Object } \\
\text { Object }\end{array}$ & $\begin{array}{c}\% \text { v. d. standaard } \\
\% \text { of the standard }\end{array}$ \\
\hline & & & \\
24 & 730 & 0 & 0 \\
40 & 63 & 0 & 0 \\
45 & 225 & 6 & 3 \\
48 & 247 & 18 & 7 \\
64 & 707 & 53 & 10 \\
66 & 192 & 19 & 2 \\
69 & 429 & 9 & 16 \\
72 & 388 & 64 & 36 \\
88 & 496 & 179 &
\end{tabular}

\subsubsection{Proeven met aardappel als toetsplant}

Hoewel uit verschillende in de volgende hoofdstukken te beschrijven proeven aangaande het virustransport in de aardappelplant ook op andere wijze gegevens werden verkregen over het moment van het uittreden van het virus uit het geïnoculeerde blad, voerden wij enkele proeven uit onder toepassing van de in 1.3.1 beschreven methode.

\section{Proef 1}

Op 26 februari 1953 werden 18 aardappelplanten (ras Bintje) van vier weken oud geïnoculeerd op het topblaadje van het jongste, volkomen ontwikkelde blad. $\mathrm{Na} 1,2,4,5,6$ en 7 dagen werd telkens van drie planten het gehele geinoculeerde blad verwijderd. Drie weken later werden de toppen van de planten, waarvan er enkele reeds ziektesymptomen vertoonden, op de aanwezigheid van het X-virus met Gomphrena globosa getoetst. Het resultaat was, dat alle planten, waarvan het geïnoculeerde blad na zes en zeven dagen was afgeknipt, ziek bleken, de overige waren gezond. Onder de gegeven omstandigheden had het virus dus het geïnoculeerde blad verlaten tussen de vijfde en de zesde dag na de inoculatie. Tegelijkertijd werd nog nagegaan, hoe de concentratie van het virus in het geïnoculeerde blad was. Het bleek, dat hierin reeds na drie dagen virus kon worden aangetoond en dat op de vijfde dag na de inoculatie reeds een vrij hoge concentratie aanwezig was. In deze proef verliet het virus het geïnoculeerde blad dus pas, nadat het hierin een vrij hoge concentratie had bereikt. 


\section{Proef 2}

Op 8 augustus 1953 werden 36 aardappelknollen (ras Bintje) gepoot. Op 2 september daaropvolgend werden negen planten geinnoculeerd op het topblaadje van het jongste, volkomen ontwikkelde blad, 15 planten op een topblaadje van een blad ongeveer halverwege de stengel en 12 planten op een topblaadje van het laagstgeplaatste, normale blad van de plant. Deze proefopzet was gekozen om na te gaan of er verschil bestaat in het tijdstip van het uittreden uit het geinoculeerde blad bij bladeren op verschillende hoogten van de plant. Het afknippen van alleen het geinoculeerde blaadje van telkens drie planten vond plaats na één, drie en vier dagen bij de eerste groep, bij de tweede groep drie, vier, vijf en zes dagen en bij de derde groep vijf, zes, zeven en acht dagen na de inoculatie. Op de dag, waarop het blaadje werd afgeknipt, werd tevens de top uit de planten genomen om de vorming van nieuwe scheuten te bevorderen, daar wij meenden, dat het virus hierin waarschijnlijk gemakkelijker kon worden aangetoond. Op 28 september werden de nieuwe scheuten alle nog gezond bevonden en ook bij een tweede toetsing op 23 oktober kon geen virus worden aangetoond. Daar het naderhand ook niet in de knollen kon worden aangetoond, was het virus op de dag, waarop de laatste keer de geïnoculeerde bladeren werden afgeknipt, blijkbaar nog niet de stengel binnengevoerd.

\section{Proef 3}

Op 24 juni 1954 werden 108 aardappelknollen (ras Voran) in potten in een warenhuis gepoot. De planten werden op één stengel gehouden en op 11 augustus werden 54 ervan op een topblaadje van een volgroeid blad in de top van de plant geinoculeerd, terwijl de 54 overige planten werden geïnoculeerd op een topblaadje van een der bladeren aan de basis van de plant. Bij de helft van de planten van elk der beide groepen werd het stengeldeel boven het geïnoculeerde blad afgeknipt om de eventuele invloed hiervan na te gaan en te zien of de negatieve uitkomsten, verkregen in proef 2 hieraan moeten worden toegeschreven. $\mathrm{Na} 2,3,4,5,6,7,8,9$ en 10 dagen werd van elk der vier groepen telkens van drie planten het geïnoculeerde blaadje afgeknipt. Bij de laatste keer werden alle op die dag afgeknipte blaadjes op de aanwezigheid van het virus getoetst met G.globosa. Het bleek, dat in 10 van de 12 blaadjes virus kon worden aangetoond, terwijl het aantal vlekjes, dat ontstond, betrekkelijk gering was. Dit wijst er op, dat de concentratie van het virus niet hoog was en er dus slechts een geringe virusvermeerdering had plaats gevonden. Vier weken na de inoculatie werden de toppen van de planten getoetst op de aanwezigheid van het virus. Het resultaat was, dat slechts bij drie planten het virus er kon worden aangetoond. Dit waren alle drie planten, die op een van de bladeren aan de basis van de plant waren geinnoculeerd en waarvan de stengel boven het geīnoculeerde blad was afgeknipt (resp. na 7, 9 en 10 dagen). Op 9 september werden de aardappelen gerooid en in 1955 werden de knollen gepoot en getoetst. Het bleek, dat slechts bij één plant zieke knollen aanwezig waren en wel aan één van de planten, waarin ook in de top virus was aangetoond. We zien hier dus, dat 10 dagen na de inoculatie vrijwel geen virus uit het geïnoculeerde blad was gevoerd. 


\section{Proef 4}

Op 22 juli 1954 werden van de aardappelrassen Bintje, Bevelander, Eigenheimer en Voran elk 40 knollen in potten in een warenhuis gepoot. De planten hielden wij na opkomst op één stengel en inoculeerden ze met het aardappel $X$-virus op 11 september op het topblaadje van een volgroeid blad in de top van de plant; $2,3,4,5,6,7,8,9,11,12,13,14$ en 16 dagen na de inoculatie werd van drie planten van elk der rassen telkens het geïnoculeerde blad afgeknipt. De blaadjes, die na 11 dagen werden afgeknipt, toetsten wij alle op de aanwezigheid van het X-virus met behulp van $G$.globosa. Het resultaat van deze toetsing was, dat bij Bintje in alle drie blaadjes en bij de andere drie rassen in elk slechts één blaadje virus kon worden aangetoond. Op 19 en 20 oktober werden alle planten gerooid. In 1955 werden de geoogste knollen gepoot en na toetsing van de hieruit verkregen planten bleek, dat uit geen der knollen zieke planten waren opgegroeid en dat dus blijkbaar bij geen enkele plant binnen 16 dagen het virus uit het geïnoculeerde blad was gevoerd.

Uit de hier beschreven proeven omtrent het transport van het aardappel Xvirus uit het geinoculeerde blad bij aardappel valt op te maken, dat het onmogelijk is de duur aan te geven van het tijdsverloop tussen de inoculatie en het verlaten van het geïnoculeerde blad. Slechts in de eerste proef werden enkele gegevens verkregen, waarbij opgemerkt kan worden, dat hier met jonge planten werd gewerkt en het is daarom jammer, dat in proef 2 de tijdstippen van het afknippen iets te vroeg gekozen werden, waardoor hier, ook bij jonge planten, geen gegevens werden verkregen. Daar in proef 2 - na inoculatie op een oud blad - na acht dagen nog geen virus uit het geinoculeerde blad was gevoerd, is het misschien juist, te veronderstellen, dat het transport uit een ouder blad iets minder snel is dan uit een jong blad. In de proeven 3 en 4 werd gewerkt met respectievelijk 48 en 51 dagen oude planten en werd na 10, respectievelijk 16 dagen nog geen transport uit het geïnoculeerde blad waargenomen. De leeftijd van de plant speelt hier waarschijnlijk een rol, hoewel uit de enkele hier gegeven resultaten hierover niets met zekerheid kan worden gezegd.

\subsection{BESPREKING VAN DE RESULTATEN}

Uit de resultaten, verkregen met tabak, Physalis floridana en aardappel blijkt, dat het tijdstip, waarop het aardappel X-virus uit het geïnoculeerde blad wordt gevoerd, afhankelijk is van verschillende factoren, zoals waardplant en ouderdom van het blad of van de plant. Eveneens komt duidelijk naar voren, dat in een bepaalde proef steeds verschillen aanwezig zijn tussen de planten onderling (zie b.v. tabel 4).

Zoals reeds door verschillende onderzoekers voor enkele virussen werd aangetoond (BAWDEN \& PIRIE, 1953; YARWOOD, 1952) treedt kort na de inoculatie een periode op, waarin de concentratie van het virus afneemt, althans indien deze werd nagegaan met behulp van toetsplanten. STEERE (1952) heeft hetzelfde nagegaan voor T.M.V. in tabak met behulp van de elektronenmicroscoop. Hij vond gedurende de eerste periode ( 20 uren) geen verandering in het aantal virusdeeltjes. HARRISON (1956) kwam na onderzoek met een tabaksnecrosevirus tot de conclusie, dat de vermindering, die kort na de inoculatie kan worden waargenomen, slechts schijnbaar is. Deze zou nl. toegeschreven moeten worden aan 
inactivering van virusdeeltjes, die na de inoculatie door een of andere oorzaak niet tot vermeerdering zijn gekomen. De vermeerdering van het virus gedurende de eerste periode na de inoculatie wordt volgens hem aanvankelijk overvleugeld door de inactivering van het virus, dat bij de inoculatie wel op het blad is gebracht, maar hierin niet is aangeslagen.

Tijdens de eerste fase vindt het virustransport waarschijnlijk plaats van cel tot cel. De snelheid van deze verplaatsing is door KöHLER (1956) voor het aardappel X-virus in tabaksbladeren bepaald. De grootste door hem gevonden snelheid was $0,083 \mathrm{~mm} /$ uur. In vroegere proeven (KöHLER, 1947) vond hij voor hetzelfde virus in tabak $0,013 \mathrm{~mm} /$ uur. De verschillen verklaart hij door aan te nemen, dat de plaats van het blad, waar het virus is ingebracht, van belang kan zijn en er, b.v. in de omgeving van de nerven, langgerekte cellen aanwezig zijn, waardoor het transport naar het floëem sterk kan worden versneld. Nadat het virus na de eerste uitbreiding het floëem heeft bereikt, vindt de verdere verspreiding ervan zeer veel sneller plaats. Daar de aanvankelijke uitbreidingssnelheid in het blad dus betrekkelijk gering is, is het tijdstip, waarop het virus het floëem bereikt, waarschijnlijk afhankelijk van de plaats, waar de infectie is begonnen. Het is denkbaar, dat de variabiliteit tussen de planten onderling met betrekking tot het moment, waarop het virus uit het geïnoculeerde blad wordt gevoerd, mede door deze factor wordt bepaald.

Dat na inoculatie met een verdunde virusoplossing het virus slechts betrekkelijk korte tijd later uit het geïnoculeerde blad wordt gevoerd dan na inoculatie met een onverdunde virusoplossing, kan als volgt worden verklaard. In het algemeen zal de periode, die verloopt vóór een geïnoculeerd virusdeeltje aanleiding kan geven tot transport uit het geïnoculeerde blad aan schommelingen onderhevig zijn. Hoe meer virusdeeltjes bij de inoculatie, hoe groter kans, dat zo snel mogelijk virus uit het geïnoculeerde blad wordt gevoerd. Bij een geringer aantal virusdeeltjes bij de inoculatie is deze kans kleiner en zal er in het algemeen iets later virus uit het geïnoculeerde blad worden gevoerd.

Voor tabak en $P$. floridana blijkt het tijdstip van het uittreden uit het geinoculeerde blad ongeveer hetzelfde te zijn. $\mathrm{Bij}$ aardappel daarentegen ligt het, voorzover althans uit de hier beschreven proeven is af te leiden, aanmerkelijk later. Het lijkt zelfs, alsof er zich omstandigheden kunnen voordoen, waarbij het virus in het geheel niet meer uit het geïnoculeerde blad wordt gevoerd, zie 1.3.4 de proeven 3 en 4 . Hoewel over dit onderwerp nog nadere gegevens zullen volgen, zij er hier thans reeds op gewezen, dat de fysiologische processen, die in een blad van een betrekkelijk jonge aardappelplant optreden, totaal kunnen verschillen van die, welke in een blad optreden in het stadium, waarop de knolvorming reeds een aanvang heeft genomen. 
HOOFDSTUK 2

\section{HET TRANSPORT VAN AARDAPPEL X-VIRUS DOOR DE STENGEL VAN DE AARDAPPELPLANT}

\subsection{INLEIDING}

Nadat een virus uit het geïnoculeerde blad in de stengel is gekomen, begint het transport ervan naar de andere plantedelen, zoals de bladeren, de groeitop; de wortels en ook, zoals bij de aardappel, naar de knollen. Dit transport heeft verschillende aspecten, zoals:

1. de snelheid, waarmee het virus wordt getransporteerd,

2. de weg, waarlangs het transport plaats vindt,

3. de richting, waarin het virus wordt getransporteerd,

4. de vorm, waarin het virus wordt getransporteerd,

5. de fysiologische processen, die het transport tot stand brengen.

Niet alle hier genoemde punten zijn van even groot belang bij het oplossen van het vraagstuk van het virustransport bij de aardappel. Toch komen verschillende ervan herhaaldelijk in een of andere vorm naar voren, omdat er een sterke samenhang tussen de verschillende punten bestaat.

Bij het vraagstuk aangaande het virustransport in de aardappelplant gaat het voornamelijk om het tijdstip van de knolbesmetting en is dus de snelheid van. het virustransport belangrijk. Hoewel de in dit hoofdstuk te beschrijven proeven ook gegevens bevatten omtrent het tijdstip van de knolbesmetting, ligt hier meer de nadruk op het transport van het virus door de stengel. In hoofdstuk 3 zal dan meer speciaal de knolbesmetting onder ogen worden gezien. Het zal blijken, dat een al te strikte scheiding niet mogelijk is. Als criterium is aangehouden, dat in dit hoofdstuk die proeven worden besproken, die het virustransport zowel in op- als neerwaartse richting tot onderwerp hebben.

\subsection{LITERATUUR}

Omtrent het transport van virussen door de stengel van de aardappelplant is weinig bekend. Van de resultaten, verkregen met andere toetsplanten volgt hier een kort overzicht.

Verschillende onderzoekers hebben het tijdstip bepaald, waarop een virus uit een geïnoculeerd blad een andere plaats in de plant bereikt. Bij het bezien van de resultaten valt op, dat ook hier uiteenlopende gegevens werden verkregen. CAPOOR (1949) heeft uit een aantal van de toen bekende gegevens van verschillende onderzoekers de snelheden van virustransport berekend en samengevat. Hieruit blijkt, dat in de gevallen, waarbij mag worden aangenomen, dat het virus door het floëem wordt vervoerd (en dus niet van cel tot cel), de snelheid van b.v, tabaksmozaïekvirus in tomaat variëert van $0,125 \mathrm{~cm} /$ uur (BöNING, 1928 ) tot $17,78 \mathrm{~cm} /$ uur (KUNKEL, 1939). Ook voor andere met sap over te 
brengen vir-ussen worden waarden van dergelijke grootte aangegeven. CAPOOR zelf vond $v$ oor tabaksmozaïek-, aardappel X- en tomate-aucubamozaïekvirus (alle op tomaat) een snelheid van 7-8 cm/uur. Slechts voor een virus, dat alleen door cicadelliden kan worden overgebracht, worden snelheden opgegeven, die aanzienlijk hoger liggen, nl. voor het curly-top virus van de biet: $152,4 \mathrm{~cm} / \mathrm{uur}$ (BENNETT, 1 934). KöHLER (1956) heeft nog geëxperimenteerd met de aardappelvirussen $X$ en $Y$ in tabak en vond hiervoor respectievelijk $0,2-0,3$ en $0,6-0,7$ $\mathrm{cm} / \mathrm{uur}$, welke waarden wel overeenstemmen met die, welke voor andere met sap over te brengen virussen werden gevonden.

Omtrent de richting, waarin het virus wordt vervoerd stuiten we in de literatuur op vele schijnbaar tegenstrijdige gegevens. Zo vond SAMUEL (1934), werkend $m$ et T.M.V. en tomaat als toetsplant allereerst transport naar de wortels en van daar bleek het virus zeer kort daarop naar de top van de plant te worden get ransporteerd. De snelheid van op- en neerwaarts transport zou ongeveer gelijk zijn. Soms werd ook wel eerst transport in opwaartse richting gevonden, alIeen dan echter, wanneer bloemen of vruchten werden gevormd. KUNKEL (1 939) werkte met hetzelfde virus, ook in tomaat en kon de door SAMUEL ge geven feiten niet geheel bevestigen. Hij vond nl. gelijktijdig transport in op- en neerwaartse richting, terwijl CALDWELL (1934) had gevonden, dat het virus het exerst naar de top van de plant werd getransporteerd. PANOS (1948) heeft hetzelfde nog eens nagegaan voor T.M.V. en aardappel X-virus, ook weer met tomaat als toetsplant. $\mathrm{Hij}$ vond in beide richtingen een gelijke transportsnelheid en. veronderstelde, dat de plaats van het geïnoculeerde blad mogelijk van invloed was op de richting van het virustransport en dat aldus de tegenstrijdigheden in de literatuur tot elkaar konden worden gebracht. Ook CAPOOR (1949) toor de aan, dat het transport van T.M.V. in tomaat zowel naar boven als naar bene $\exists$ en of ook in beide richtingen tegelijk kan plaats vinden. Volgens hem zou tr-ansport in neerwaartse richting in de meeste gevallen het eerst voorkomen.

Vele autzeurs (SAMUEL, 1934; KunKEL, 1939; STAPP \& MARCUS, 1945) vermeldden reeds, dat in de stengel stukken kunnen voorkomen, die vrij zijn van virus, terw ijl uit de gegevens blijkt, dat het virus het desbetreffende stengelstuk gepasseerd 13 moet zijn, zonder er een infectie tot stand te hebben gebracht. Dit laatste is een bewijs, dat het virustransport in de plant niet plaats vindt door een continue $v$-ermeerdering ervan, zoals b.v. door CALDWELL (1934) en GraINGER (1932) nog $\leftrightharpoons$ werd verondersteld.

Het vircustransport moet veel meer worden gezien als een transport van de „,infectieu $\approx e$ eenheid" over grote afstanden. Hoe dit transport plaats vindt en in welke vorm, is nog niet geheel opgehelderd. Verschillende auteurs concludeerden, dat $\mathbf{h}$ _et virustransport in verband staat met het voedseltransport. SAMUEL (1934) me-ende dit op grond van zijn waarneming, dat het virustransport in opwaartse= richting sneller plaats vond, indien de plant in het stadium van de bloem- en vruchtvorming verkeerde. BENNETT $(1937,1940)$ gaf steun aan deze opvatting door de resultaten van zijn proeven met verduisterde plantedelen, waaruit bIleek, dat het virustransport hiernaar sneller geschiedde dan naar niet verduister de. FulToN (1941) inoculeerde de wortels van tabak met T.M.V. en vond, dat in deze wortels het virustransport veel gemakkelijker in neerwaartse richting $\mathbf{p}$. Jaats vond dan in opwaartse richting en concludeerde hier ook uit, dat het træansport met de assimilatenstroom zou meegaan. Tegenover deze ge- 
gevens staan echter ook andere, waaruit zou blijken, dat het virustransport ook in een richting, tegengesteld aan die der assimilatenstroom (dit is de heersende sapstroom), kan plaats hebben. Zo vonden b.v. CALDwell (1934) en RoBERTS (1952) dat het virus van verduisterde bladeren uit werd getransporteerd.

\subsection{EIGEN ONDERZOEK}

\subsubsection{Materiaal en methoden}

Bij het onderzoek aangaande het transport van het aardappel X-virus in de aardappelplant werd steeds gewerkt met eenstengelige planten afkomstig van goedgekeurd pootgoed. Voordat de proeven werden ingezet, werden de planten steeds gecontroleerd op de aanwezigheid van virusziekten en werden alle afwijkende planten verwijderd. Om het transport door de stengel te kunnen vervolgen, werd in enkele proeven gebruik gemaakt van een werkwijze, waarbij de stengel van enkele planten op gezette tijden na de inoculatie in stukken werd gesneden (BEEMSTER, 1953). Om de aanwezigheid van het virus in deze stukken aan te kunnen tonen, werden deze, na een groeistof behandeling ( $\beta$-indolylazijnzuur, $1 \%$ in poedervorm), in een geschikt grondmengsel geplaatst, waarna in de meeste gevallen een snelle beworteling optrad.

In de aldus verkregen stekplanten kon het eventueel aanwezige virus tot vermeerdering komen. De planten of de knollen ervan werden dan naderhand op de aanwezigheid van het virus getoetst. Uit enkele kleine proeven, eveneens met aardappel, was gebleken, dat een behandeling met de groeistof geen inactiverende invloed op het aardappel X-virus heeft, zodat de methode zonder bezwaar kon worden toegepast. De proeven werden, voor zover onder kasomstandigheden werd gewerkt, uitgevoerd bij een temperatuur van $22-24^{\circ} \mathrm{C}$. In de volgende paragrafen zal met toetsing van knollen worden bedoeld, dat de planten, die uit de knollen opgroeiden, werden getoetst.

\subsubsection{Het transport door de stengel, bepaald volgens de stekmethode}

Reeds eerder (BEEMSTER, 1953) werden enkele resultaten van proeven betreffende het transport van het aardappel X-virus door de stengel van de aardappelplant gepubliceerd. Aangezien enkele van de thans te beschrijven proeven nauw daarbij aansluiten, volgt hier nog een korte samenvatting van de resultaten.

Eenstengelige aardappelplanten (ras Bintje, in het veld gepoot op 25 april 1952) werden in twee groepen verdeeld, die wij op 21 juni (hoogte van de planten ca. $30 \mathrm{~cm}$ ) en op 11 juli (hoogte van de planten ca. $50 \mathrm{~cm}$ ) met het aardappel $\mathrm{X}$-virus inoculeerden. Op de beide data vond de inoculatie plaats, bij de helft van de planten op een blad in de top en bij de andere helft op een blad aan de basis. Te beginnen drie dagen na de inoculatie, werden om de twee of drie dagen van twee planten van elke groep een drietal stekken gemaakt en werden ook de knollen van die planten gerooid. Na de toetsing van de knollen, afkomstig van de stekken en van de moederplanten (van de laatste drie knollen per plant), bleek het volgende. $\mathrm{Na}$ inoculatie op 21 juni in de top was na vier dagen nog geen transport opgetreden; op de vijfde en zesde dag na de inoculatie werden geen stekken gesneden en reeds na zeven dagen bleek het virus door de gehele stengel en naar de knollen te zijn getransporteerd. Op de daarop volgende dagen werd ook steeds een dergelijk resultaat verkregen. Opgemerkt dient, dat 
soms tussen de geïnfecteerde stengeldelen gezonde stukken werden aangetroffen en dat in de nateelt van een moederplant zowel zieke als gezonde knollen voorkwamen. De inoculatie op 21 juni op een van de bladeren aan de basis van de plant gaf een geheel ander beeld te zien. Transport door de stengel in opwaartse richting had in het geheel niet plaats gevonden, terwijl pas 17 dagen na de inoculatie een zieke knol aan de moederplant werd gevonden. Het transport in neerwaartse richting was dus zeer vertraagd. Overigens bleken lang niet alle planten na de $17 \mathrm{e}$ dag zieke knollen te hebben, waardoor de indruk werd verkregen, dat het virustransport uit de oudere bladeren zeer moeilijk is. De inoculatie van 11 juli, op drie weken oudere planten dus, gaf na de inoculatie in de top ook hier een zeer vertraagd virustransport in vergelijking met de inoculatie op 21 juni te zien. Pas na 13 dagen werd voor het eerst transport geconstateerd. De inoculatie van 11 juli op een der onderste bladeren gaf nog minder infectie te zien dan na de inoculatie op 21 juni. De meest markante resultaten van deze proef waren dus:

1. De inoculatie van een oud blad aan de basis van de plant resulteerde in het geheel niet in een opwaarts transport van het virus.

2. Het virus passeerde stengelstukken, zonder deze te besmetten.

3. De nateelt van een plant leverde verschillende malen zowel zieke als gezonde knollen op.

4. In jonge planten geschiedt het virustransport sneller dan in oude planten.

5. Het virus wordt gemakkelijker uit een topblad getransporteerd dan uit een blad aan de basis van de plant.

Daar bij de boven beschreven proef na inoculatie van een topblad op de vijfde en zesde dag na de inoculatie geen stekken werden gesneden, werd dat gedeelte van de proef nog eens nader onderzocht. De proef werd in de kas uitgevoerd met aardappelplanten van het ras Voran, die gepoot waren op 20 juli 1953. Van deze planten werden op 13 augustus 40 stuks op het jongste, volkomen ontplooide blad geïnoculeerd. De hoogte van de planten was toen gemiddeld $30 \mathrm{~cm}$ en ze hadden het stadium van de knolvorming nog niet bereikt. Op 14, $15,16,17,18,19,20$ en 21 augustus, dus een tot en met acht dagen na de inoculatie, werden telkens de gehele stengels van vijf planten in vijf tot zes stukken gesneden. Deze stukken werden op de reeds beschreven wijze tot beworteling gebracht, hetgeen bij deze jonge planten voor $100 \%$ slaagde. Daar de planten nog geen knollen gevormd hadden, kon hierin de aanwezigheid van het virus niet worden bepaald. Daarom werd het onderste deel van de stengel na het snijden van de stekken niet opgeruimd, maar weer tot nieuwe groei gebracht, waardoor ook hierin de aanwezigheid van het virus kon worden bepaald. In deze proef werden de nieuw ontplooide scheutjes van de stekken op de aanwezigheid van virus getoetst met Gomphrena globosa. De resultaten zijn weergegeven in figuur 1, waarin de planten als een aantal aaneensluitende stengeldelen zonder bladeren, zijn weergegeven. De lengte van de stukken is in de juiste verhouding getekend en het geheel geeft dus ook een beeld van de lengtegroei van de planten, die zoals te zien is, tot het einde van de proef voortgang vond. Het geïnoculeerde blad bleef bij het in stukken snijden van de stengel aan het desbetreffende stengeldeel bevestigd. Tijdens het tot beworteling komen van dit deel was er dus gelegenheid, dat het virus hierin doordrong, voor zover dit nog niet was geschied. Gezien het feit, dat alle stengelstukken, waaraan het 

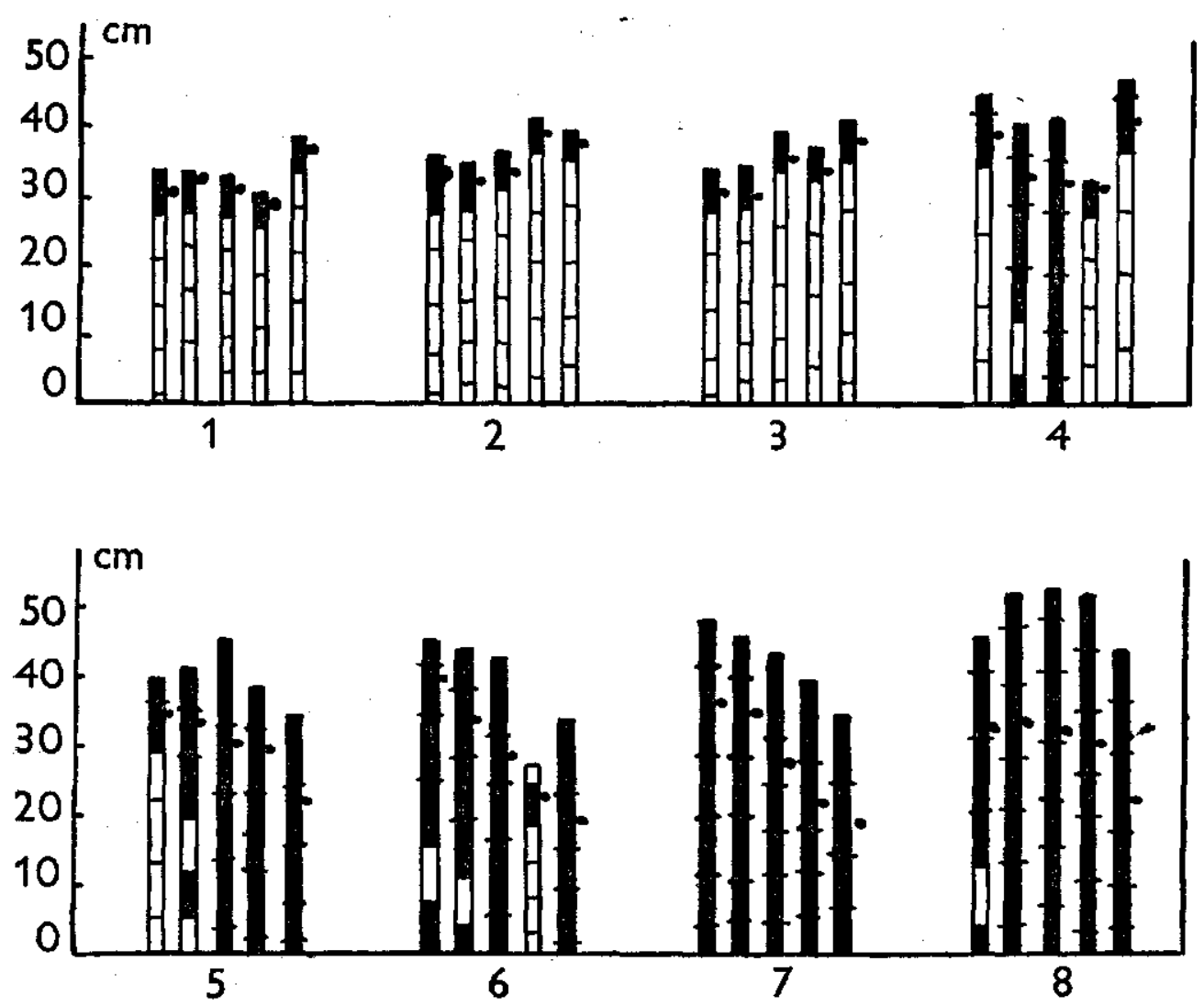

Fig. 1. Het transport van $\mathrm{X}$-virus in de stengel van de aardappel na inoculatie van een topblad. De planten van de groepen 1-8 werden resp. 1-8 dagen na de inoculatie in stukken gesneden en gestekt. In elke groep zijn vijf planten schematisch getekend. De gezond bevonden stengeldelen zijn wit aangegeven, de zieke zwart. Aan de met 0 gemerkte bladeren was het geïnoculeerde blad bevestigd.

The translocation of virus $X$ in the stem of potato after inoculation of a top leaf. Cuttings of the plants in the groups $1-8$ were made $1-8$ days after inoculation resp. In each group five plants are drawn schematically. In case a cutting proved to be healthy, this is indicated by white; in case it was infected, by black. The parts marked with are those to which the inoculated leaves were attached.

geinoculeerde blad was bevestigd, werden besmet, mag worden aangenomen, dat de inoculatie in alle gevallen was geslaagd. De eerste drie dagen na de inoculatie heeft in geen enkele plant transport plaats gevonden. Hoewel in figuur 1 het bovenste stuk van de stengels van de groepen 1,2 en 3 zwart is weergegeven, wil hiermee niet worden aangeduid, dat het virus reeds in deze stengelstukken aanwezig was op het tijdstip dat de stengels tot stekken werden versneden. Op de vierde dag na de inoculatie werd bij twee van de vijf planten virustransport in de stengel geconstateerd tot en met het onderste gedeelte daarvan. Bij een van deze twee planten is een stengelstuk gezond gebleven. We zien verder, dat op deze dag ook stekken konden worden gesneden boven het geïnoculeerde blad en dat bij twee van de drie planten, die geen transport in neerwaartse 
richting te zien hebben gegeven, wel transport naar boven plaats vond. De planten, waarbij wel transport in neerwaartse richting geschiedde, vertoonden bovendien transport naar boven. Uit deze gegevens blijkt, dat onder de hier geschetste omstandigheden het virustransport eerst naar boven en dan naar beneden gaat. Over het algemeen is het beeld vijf dagen na de inoculatie hetzelfde als na vier dagen; hier vinden we echter al in vier van de vijf gevallen transport in beide richtingen en in slechts één geval alleen in opwaartse richting. Tenslotte zien we, dat na 6,7 , en 8 dagen het transport bij vrijwel alle planten reeds in beide richtingen heeft plaats gevonden. Ook thans zijn nog enkele stengeldelen onbesmet gebleven; het betreft, zoals te zien is, meestal de lagere stengelgedeelten. Merkwaardig is nog, dat in de vierde plant van groep 6 in het geheel geen virustransport heeft plaats gevonden. Uit de figuur is op te maken, dat de lengte van deze plant bij die van de andere ten achter is gebleven. Mogelijk heeft deze plant te kampen gehad met groeistoornissen, die ook het transport van het virus hebben vertraagd.

Uit de gegevens kan het volgende beeld worden opgemaakt over het transport van het virus in de stengel van vrij jonge aardappelplanten na inoculatie op een van de topbladeren. Het virus blijft drie tot vier dagen in het geinoculeerde blad, komt daarna eerst in het nog groeiende topgedeelte van de plant en gaat kort hierna eveneens naar de basis van de plant en wel in een tijdsbestek van hoogstens 24 uren, hetgeen zou neerkomen op een minimale snelheid van $40: 24=1,67 \mathrm{~cm} /$ uur.

Een tweede proef betrof het transport van het aardappel $\mathrm{X}$-virus in jonge planten na inoculatie op een der laagstgeplaatste bladeren. Hiertoe werden 24 dagen oude aardappelplanten van het ras Voran (30 stuks) gebruikt. Gezien de eerder verkregen resultaten met het ras Bintje (oudere planten), waar na 30 dagen nog geen virustransport in opwaartse richting werd geconstateerd, werden hier pas zes dagen na de inoculatie voor het eerst van vijf planten stekken gesneden. Vervolgens ook nog 7, 8, 9, 10 en 11 dagen na de inoculatie. De resultaten van de toetsing van de stekken leerden, dat reeds op de zesde dag na de inoculatie het virus tot in de top van de planten was doorgedrongen. Ook in deze proef werd nog een enkele maal een gezond stengelstuk tussen de zieke aangetroffen. Het begin ven het transport in opwaartse richting kon uit de gegevens niet worden bepaald. Het is echter wel duidelijk gebleken, dat het virus na de inoculatie op een van de lagere bladeren naar boven kan worden getransporteerd en wel met een snelheid, die waarschijnlijk niet veel verschilt met die van het transport in neerwaartse richting. De vroegere proeven zijn blijkbaar uitgevoerd met te oude planten om transport in opwaartse richting te zien te kunnen geven.

\subsubsection{Het transport door de stengel, bepaald door directe toetsing op toetsplanten}

Zoals reeds uit een van de voorgaande proeven duidelijk is geworden, kan, onder zekere omstandigheden, het transport van het aardappel $\mathrm{X}$-virus uit jonge bladeren aanzienlijk sneller plaats vinden dan uit oude bladeren. In de bedoelde proeven werd echter alleen geïnoculeerd op een van de oudste of op een van de jongste bladeren van een plant. Een juiste conclusie omtrent de invloed van de plaats van het geïnoculeerde blad in het algemeen was daarom niet mogelijk.

In een kasproef hierover werden 84 aardappelplanten (ras Voran, poot- 
datum: 6 juni 1953) op 1 juli 1953 geïnoculeerd met het aardappel X-virus. De planten waren zeer gelijkmatig opgegroeid en hadden op het moment van de inoculatie een lengte van ca. $40 \mathrm{~cm}$ bereikt. Op deze datum waren bij enkele planten zeer kleine knolletjes aanwezig. Het schema van de proef was als volgt. De planten werden in vier groepen van 21 planten verdeeld, die respectievelijk werden geïnoculeerd op het jongste, geheel ontplooide blad; op een blad op ongeveer $30 \mathrm{~cm}$ hoogte; een blad op ongeveer $20 \mathrm{~cm}$ hoogte en een op een hoogte van ongeveer $10 \mathrm{~cm}$ boven de grond. Van elk der vier groepen werden 12,19 en 26 dagen na de inoculatie telkens zeven planten gerooid. De knollen werden per plant afzonderlijk bewaard. Op het tijdstip van rooien werd bovendien van elke gerooide plant de top op de aanwezigheid van het virus met Gomphrena globosa getoetst. Op deze wijze kon dus worden bepaald wanneer en in welke richting het virustransport door de stengel had plaats gevonden. De toetsing met $G$.globosa is zoals in paragraaf 1.3 .2 werd aangetoond weliswaar niet geheel betrouwbaar in proeven als deze, maar geeft toch wel enig inzicht.

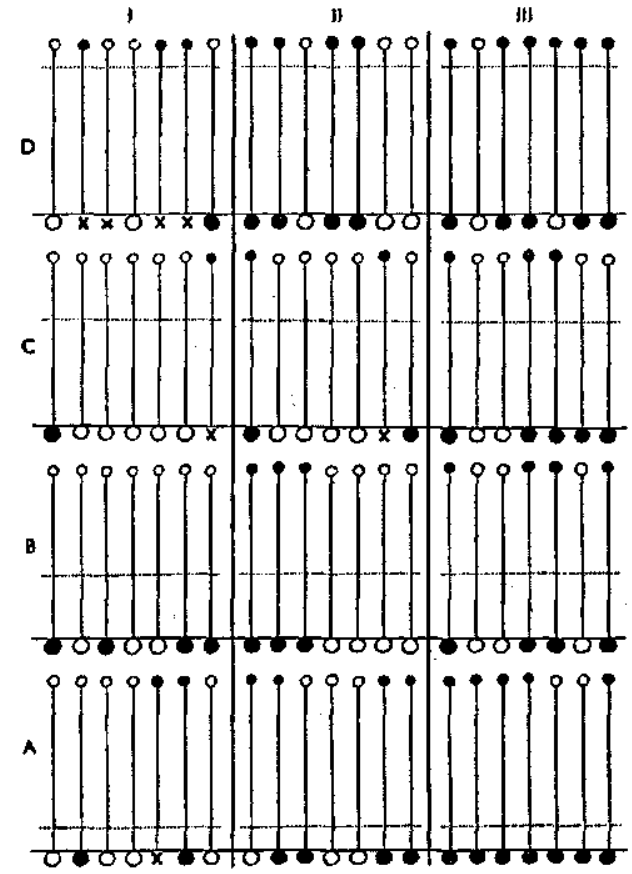

FIG. 2. Transport van aardappel X-virus in Voran na inoculatie van een blad op resp. 10 (A), 20 (B), 30 (C) en $40 \mathrm{~cm}$ (D) hoogte. De toppen van de planten in elke groep werden getoetst en de knollen ervan werden gerooid resp. 12 (I), 19 (II) en 26 dagen (III) na de inoculatie. $-=$ top of knol geinfecteerd; $0=$ top of knol gezond; ...... = positie van het geïnoculeerde blad; $x=$ geen knol gevormd.

Translocation of potato virus $X$ in Voran potato after inoculation of a leaf at heights of $10(A), 20(B), 30(C)$ and $40 \mathrm{~cm}(D)$ resp. The tops of the plants in each group were tested and their tubers were harvested $12(I), 19$ (II) and 26 days. (II) after inoculation resp. - top or tuber infected; $\mathbf{0}=$ top or tuber healthy;...... = position of the inoculated leaf; $\mathrm{x}=$ no tuber formed. 
De resultaten van de proef zijn in figuur 2 weergegeven. We zien, dat 12 dagen na de inoculatie het virus bij een aantal planten, die reeds knollen hadden gevormd, hierin ook was doorgedrongen. Een merkwaardigheid geven die planten te zien, die op de dag van het rooien nog geen knollen hadden gevormd. We zien nl. dat van de zes gevallen er bij vijf virus in de top van de plant werd gevonden, terwijl bij de planten, die wel knollen hadden gevormd, het virus slechts in één van de 22 gevallen in de top kon worden aangetoond. Deze gegevens zouden er op kunnen wijzen, dat het transport van het virus in sterke mate gebonden is aan de richting, waarin de assimilatenstroom zich begeeft.

De resultaten, die verkregen werden 19 en 26 dagen na de inoculatie wijzen er op, dat in die gevallen, waarin transport werd geconstateerd, dit meestal zowel in op- als neerwaartse richting werd gevonden. In het geval, dat 19 dagen na de inoculatie werd getoetst, werden nog 13 planten gevonden, die geen virus in de top of in de knollen vertoonden; 26 dagen na de inoculatie ging het hier nog slechts om zes planten. Gedurende de laatste week heeft de besmetting dus nog steeds voortgang gevonden. Hieruit blijkt, dat het virus in veel gevallen een zeer aanzienlijke periode nodig heeft gehad om van het geïnoculeerde blad naar de top of naar de knollen te komen.

Het totale resultaat van de proef overziende, komen we tot de conclusie, dat het verschil in plaats van het geinoculeerde blad in deze proef niet tot grote verschillen in het virustransport aanleiding heeft gegeven. We moeten hierbij wel bedenken, dat gewerkt werd met het aardappelras Voran, welk ras, zoals uit nader te beschrijven proeven (Hoofdstuk 3) zal blijken, een enigszins van het ras Bintje afwijkend beeld van het transport van het aardappel $X$-virus te zien geeft.

De knollen, die van de planten van deze proef werden verkregen, werden alle gepoot en getoetst, waardoor een beeld van de knolinfectie in de verschillende groepen werd verkregen. In tabel 7 zijn de resultaten samengevat. We zien, dat ook deze cijfers geen duidelijke verschillen tussen de verschillende groepen vertonen. $\mathrm{Bij}$ het rooien na 26 dagen, op welke datum het totaal aantal knollen niet meer zo klein en de cijfers dus betrouwbaarder zijn, is toch wel duidelijk, dat de inoculatie op het onderste blad tot het hoogste percentage besmette knollen aanleiding heeft gegeven.

Bij toetsing van de knollen bleek ook hier duidelijk, dat een aardappelplant zowel zieke als gezonde knollen op kan leveren.

TABEL 7. Aantal en percentage zieke knollen met betrekking tot de plaats van het geinnoculeerde blad aan de stengel en het tijdsverloop tussen inoculatie en oogst.

Number and percentage of diseased tubers in relation to the position of the inoculated leaf at the stem and the interval between inoculation and harvest.

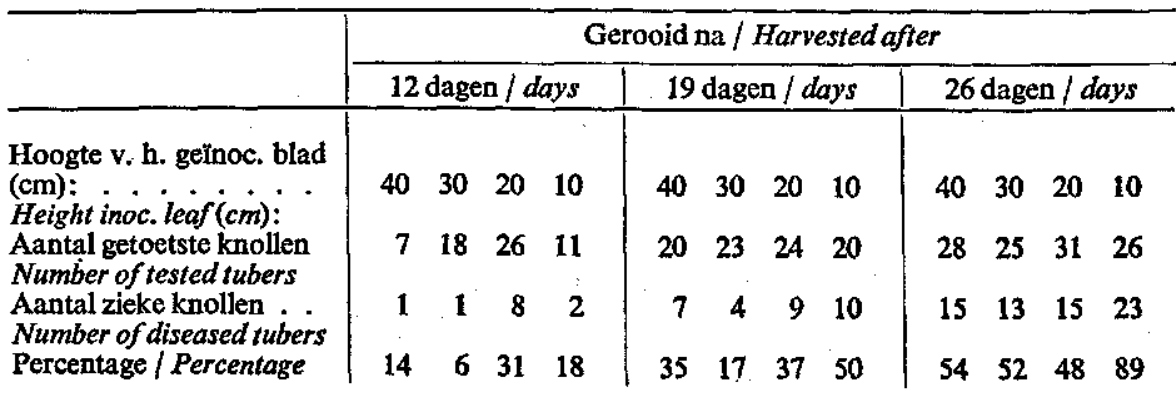




\subsubsection{Het transport van blad naar blad}

Voor de diagnose van het aardappel X-virus in de bladeren van de aardappelplant kan het van belang zijn te weten hoe lang het duurt, voordat het virus, nadat het op een bepaalde plaats de plant is binnengekomen, in andere bladeren aantoonbaar is. Hierover werd de volgende proef uitgevoerd. Op 24 augustus 1956 gepote aardappelplanten (ras Eigenheimer) werden op 25 september daaropvolgend met het aardappel X-virus geïnoculeerd. Deze inoculatie geschiedde als volgt: zeven planten $(1 \mathrm{t} / \mathrm{m} 7)$ werden geinnoculeerd op een jong blad in de top van de plant en zeven planten $(8 \mathrm{t} / \mathrm{m} 14)$ op één van de oudste bladeren aan de basis van de plant. Daar de eerste dagen na de inoculatie geen virus in aantoonbare hoeveelheden in de andere bladeren verwacht kon worden, werd pas op de zevende dag na de inoculatie voor de eerste keer van de nummers $1 \mathrm{t} / \mathrm{m}$ 4 en $8 \mathrm{t} / \mathrm{m} 11$ van acht bladeren elk een blaadje getoetst met Gomphrena globosa. Van de planten $1 \mathrm{t} / \mathrm{m} 4$ waren drie van de acht te toetsen bladeren onder het geïnoculeerde blad aan de stengel bevestigd en vijf er boven. Bij de planten van de andere groep waren alle te toetsen bladeren boven het geïnoculeerde blad aan de stengel bevestigd. Daar een normaal aardappelblad minstens zeven blaadjes heeft, kon zeven dagen lang telkens een nieuw blaadje van een blad worden getoetst, hetgeen geschiedde $7,8,9,10,11,13$ en 14 dagen na de inoculatie. Op de 14e dag na de inoculatie vertoonden de planten in de top reeds mozaieksymptomen. Van de resterende planten (de nummers $5 \mathrm{t} / \mathrm{m} 7$ en $12 \mathrm{t} / \mathrm{m} \mathrm{14}$ ) werden alleen nog die bladeren getoetst, die nog geen mozaïeksymptomen vertoonden. Deze toetsing geschiedde 15,16, 17, 18, 20, 21 en 22 dagen na de inoculatie, zodat de gehele proef tot ruim 3 weken na de inoculatie werd voortgezet en aldus een inzicht werd verkregen in de snelheid en de richting van het virustransport naar de verschillende bladeren van een plant. De resultaten van de toetsingen van het eerste gedeelte van de proef (de planten $1 \mathrm{t} / \mathrm{m} 4$ en $8 \mathrm{t} / \mathrm{m} \mathrm{11)} \mathrm{zijn} \mathrm{in} \mathrm{tabel} 8$ weergegeven. De resultaten van de toetsingen, die later dan 14 dagen na de inoculatie plaats vonden, gaven geen enkele verandering van de toestand, zoals deze 14 dagen na de inoculatie reeds was, meer te zien. Daarom zijn de hierop betrekking hebbende gegevens hier achterwege gelaten.

$\mathrm{Na}$ de inoculatie op het jongste volkomen ontwikkelde blad $(1 \mathrm{t} / \mathrm{m}$ 4) zien we, dat bij drie van de vier planten het virus na 10 dagen voor het eerst aantoonbaar was in een van de bladeren boven het geïnoculeerde blad. In de meeste bladeren boven het geïnoculeerde blad was het virus 10 tot 11 dagen na de inoculatie vrij plotseling in aantoonbare concentratie aanwezig. Een uitzondering vormt plant 4 , waar pas 13 dagen in een enkel blad virus kon worden aangetoond. Opmerkelijk is verder, dat in het blad, vlak boven het geïnoculeerde, het virus blijkbaar moeilijk doordringt, daar ook bij de drie later dan na 14 dagen getoetste planten het virus in dit blad niet kon worden aangetoond, zelfs niet na 22 dagen. In de bladeren onder het geïnoculeerde blad kon in geen enkel geval, ook niet na 22 dagen, het virus worden aangetoond. De resultaten met de tweede groep van planten wijken in principe niet af van die der eerste groep. Wel zien we, dat in deze groep er iets eerder virus aantoonbaar is in sommige van de hogere bladeren: plant 11 reeds na zeven en plant $10 \mathrm{na}$ acht dagen. Overigens zien we echter hetzelfde beeld, ook dat in het blad boven het geinoculeerde, geen virus kon worden aangetoond, ook hier niet na 22 dagen, zoals bleek uit de resultaten met de planten $12 \mathrm{t} / \mathrm{m} 14$. 
TABEL 8. Transport van het aardappel X-virus van het geìnoculeerde blad naar de bladeren in het ras Eigenheimer, bepaald door toetsing met Gomphrena globosa.

Translocation of potato virus $X$ from the inoculated leaf to the leaves in the variety Eigenheimer, detected by testing with Gomphrena globosa.

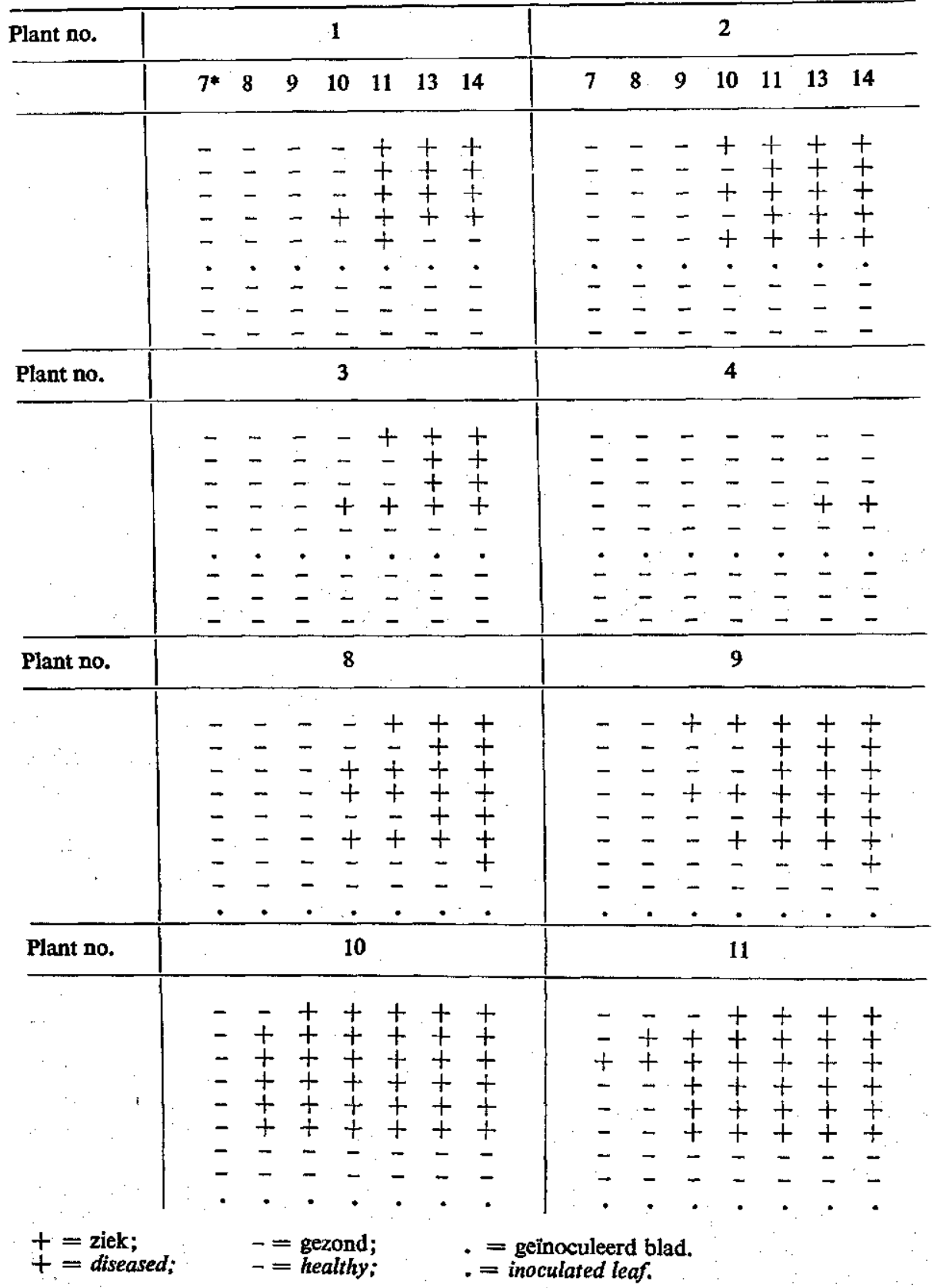

- Aantal dagen na de inoculatie / Number of days after inoculation. 
Hoewel er nog slechts een geringe knolvorming had plaats gevonden, werden de knolletjes, die verkregen werden na het rooien van de planten op de dag van het toetsen van het laatste blaadje, bewaard en naderhand getoetst. Het bleek daarbij, dat alle knolletjes reeds 14 dagen na de inoculatie ziek waren.

Bij de verklaring van de verschillende feiten, moeten we er op de eerste plaats op wijzen, dat de toetsing met Gomphrena globosa geschiedde, waardoor we, zoals uit paragraaf 1.3.2 bleek, iets te laat zijn met de diagnose en er dus virus in de door ons gezond bevonden bladeren aanwezig kan zijn geweest. Desondanks zijn enkele feiten wel duidelijk, vooral bij vergelijking van de twee groepen. We zien dan nl., dat in de eerste groep het virus niet aantoonbaar is, zelfs niet na 22 dagen, in bladeren, waarin het in de tweede groep in één geval al na acht dagen aantoonbaar was. Dit kan niet alleen een kwestie van diagnosemethodiek en ook niet van virusvermeerdering in dat blad zijn, maar kan alleen worden verklaard door aan te nemen, dat er uit het geïnoculeerde blad zeer weinig virustransport is naar die bladeren, die zelfs na 22 dagen nog geen virus hierin vertoonden (vaak het blad boven het geïnoculeerde blad en altijd de bladeren er beneden). Het is blijkbaar zo, dat virus nog wel van een geïnoculeerd blad in bladeren (behalve het er direct op volgende) er boven kan komen, maar niet naar de lagere bladeren. Het feit, dat het geinoculeerde blad wat lager of hoger aan de stengel is bevestigd, maakt blijkbaar weinig verschil wat dit betreft. Zoals uit de knolbesmetting blijkt, is het virus wel in neerwaartse richting getransporteerd, maar is het de bladeren van de stengel uit niet binnengegaan. In het algemeen is dus bij de diagnose van het aardappel $\mathrm{X}$-virus aan te bevelen, de bladeren van de top van de plant te toetsen, daar hier de meeste kans is, dat na een primaire infectie eventueel aanwezig virus kan worden aangetoond.

\subsection{BESPREKING VAN DE RESULTATEN}

De resultaten van de in dit hoofdstuk beschreven proeven tonen duidelijk aan, dat het zeer moeilijk is om een bepaald beeld van het virustransport door de stengel te verkrijgen. Er blijken verschillende factoren van belang te zijn, die niet. alleen tussen de verschillende proeven, maar ook tussen de planten van een enkele proef, verschillen teweeg kunnen brengen.

De snelheid van het virustransport in de stengel kan zeer aanzienlijk zijn, zoals uit verschillende proeven blijkt. De hier gevonden snelheid stemt wel overeen met door andere auteurs gegeven snelheden van met sap over te brengen virussen. De minimum snelheid, die door ons werd gevonden in de aardappelstengel was $1,67 \mathrm{~cm} /$ uur. Doordat verschillende planten in het algemeen nog aanzienlijke onderlinge verschillen te zien geven, is het niet gemakkelijk om de juiste snelheid of althans een betere benadering ervan, voor het aardappel $\mathrm{X}$ virus te bepalen. In ieder geval is duidelijk gebleken, dat de tijd voor het virus om van het geinnoculeerde blad naar de stengel te komen langer is dan om de afstand over de gehele lengte van de stengel af te leggen. Het is dan ook niet uitgesloten dat de snelheid, waarmede het virus de knollen van de aardappelplant bereikt, sterk afhankelijk is van de tijd, die het virus nodig heeft om uit het geinoculeerde blad te komen.

De richting, waarin het virus wordt getransporteerd, blijkt ook afhankelijk te zijn van bepaalde factoren, waarbij voor de aardappel blijkens de hier beschreven proeven speciaal de leeftijd van het blad en van de plant van belang 
zijn. De algemene lijn, die te constateren is in de verschillende proeven duidt wel op een correlatie tussen voedsel- en virustransport: in de eerstbeschreven proef werd wel transport van de top naar de knollen gevonden en niet van de basis naar de top bij planten, die reeds het stadium van knolvorming hadden bereikt. In de twee volgende beschreven proeven (2.3.2) zagen we, dat bij jonge planten (vóór de knolvorming was begonnen), zowel op-als neerwaarts transport plaats vond en in dit geval kwam eerst opwaarts transport voor. De resultaten met het ras Voran (2.3.3) zijn over het geheel genomen wat onregelmatig. In een bepaald onderdeel ervan, $\mathrm{nl}$. bij rooiïng 12 dagen na de inoculatie, kwam toch duidelijk naar voren, dat bij planten, die in het knolvormende stadium zijn gekomen een sterk neerwaarts transport van het virus plaats vindt. In de laatst beschreven proef zagen we weer, dat bij vrij jonge planten zowel op- als neerwaarts transport optreedt. De snelheid, waarmee dit geschiedde leek minder groot, wat toegeschreven moet worden aan de werkwijze, nl. de directe toetsing met Gomphrena globosa. We zien dus, dat het virustransport in principe zowel eerst in op- als neerwaartse richting kan plaats vinden. Controversen, die hierover in de literatuur bestaan, zijn dit dus eigenlijk niet, want het ontwikkelingsstadium van de plant heeft hierop, zoals uit de besproken resultaten bleek, grote invloed.

Uit de hier verkregen resultaten (zie fig. 1) blijkt ook, dat het virus bepaalde stukken stengel kan „overslaan”, dus passeren, zonder er een infectie tot stand te brengen. Dit moet wijzen op een zeer geringe virusconcentratie tijdens het transport, dat waarschijnlijk vooral in de aanvang een zeer discontinu verloop heeft. De zienswijze, dat het virus zich al vermeerderend verplaatst, is met deze discontinuiteit van het virustransport niet in overeenstemming te brengen. 
HOOFDSTUK 3

\section{HET TRANSPORT VAN AARDAPPEL X-VIRUS VAN HET GEÏNOCULEERDE BLAD NAAR DE KNOLLEN}

\subsection{INLEIDING}

In hoofdstuk 2 konden uit enkele proeven reeds conclusies worden getrokken aangaande het tijdstip van de besmetting van de knollen na inoculatie van een der bladeren. Uit de resultaten van die proeven bleek, dat het transport van het X-virus naar de knollen zeer snel kan plaats vinden. Eveneens bleek echter, dat het tijdstip van de besmetting van de knollen kan variëren, blijkbaar afhankelijk van verschillende factoren, zoals leeftijd van de plant en van het geinoculeerde blad.

In dit hoofdstuk zullen de uitvoering en de resultaten van een aantal kas- en veldproeven worden beschreven, die werden uitgevoerd om de infectie van de knollen in verband met het tijdstip van inoculatie nader te bestuderen. Hierbij werd ook aandacht besteed aan het feit, dat niet alle knollen van een plant gelijktijdig worden besmet en dat uit één knol zowel zieke als gezonde stengels kunnen opgroeien. Op een bijzonder aspect van de knolbesmetting, nl. de ouderdomsresistentie, die ook in dit hoofdstuk naar voren zal komen, zal in hoofdstuk 4 nog nader worden ingegaan.

\subsection{LITERATUUR}

Hoewel gegevens over het tijdsverloop tussen de inoculatie van het blad en de besmetting van de knollen van groot belang kunnen worden geacht bij de oplossing van vele vraagstukken betreffende de teelt van aardappelpootgoed, is in de literatuur toch weinig te vinden, dat hierop rechtstreeks betrekking heeft. En dan betreft het alleen het bladrolvirus van de aardappel. Resultaten van proeven, waarbij, na natuurlijke besmetting te velde, op verschillende tijdstippen de mate van infectie van de knollen werd nagegaan, zijn wel bekend (MüNSTER \& MAYOR, 1954), maar uit deze gegevens valt niet met zekerheid op te maken, wanneer de werkelijke infectie op het blad (b.v. door bladluizen) heeft plaats gevonden, zodat niets kan worden gezegd over de snelheid van het virustransport van het blad naar de knollen.

MURPHY \& McKAY (1926) zijn waarschijnlijk de eersten geweest, die in aardappelplanten de snelheid van het transport van het bladrolvirus hebben nagegaan. In een van hun proeven vonden zij, dat dit virus door enting van een zieke top op de gezonde plant overgebracht, na 5 en 10 dagen nog niet in de knollen was doorgedrongen, na 15 dagen echter wel. In een tweede, op dezelfde wijze uitgevoerde proef werd na zes dagen nog niet, na 14 dagen echter wel virus in de knollen aangetroffen. Uit nader onderzoek besloten de auteurs, dat, als het virus eenmaal in de stengel aanwezig was, het transport ervan naar de knollen zeer snel plaats vond. Verder werden door hen ook proeven genomen, 
waarbij zij de infectie tot stand trachtten te brengen door middel van bladluizen, maar deze proeven leidden tot geen enkele knolinfectie. De vraag, in hoeverre een infectie door enting dezelfde resultaten oplevert als een infectie door bladluizen, kon dus niet worden beantwoord.

Elze (1927) beschrijft enkele proeven over de snelheid van het transport van het bladrolvirus in de aardappelplant. De resultaten van zijn proeven laten echter geen uitspraak toe, wat betreft het tijdstip van de knolbesmetting. Zijn algemene conclusie was, dat het virus niet snel werd getransporteerd.

BRADLEY \& GANONG (1953) deden enig onderzoek over de transportsnelheid van het bladrolvirus te velde. Zij vonden na vijf dagen geen en na acht dagen wel besmette knollen. Zij vermeldden, dat alle ogen van een $\mathrm{knol}$, ook indien de infectie van de knol zeer recent had plaats gevonden, viruszieke stengels opleverden.

AUGIER DE MONTGREMIER (1954) verrichtte eveneens onderzoek aangaande het bladrolvirustransport te velde. Na zes dagen vond zij nog geen besmette knollen, maar wel na 10 dagen.

Uit de bovenvermelde gegevens zien we, dat het ongeveer 10 dagen kan duren voor het bladrolvirus in de knollen aankomt. In het algemeen waren deze proeven beperkt in hun opzet. Nog vele vraagstukken aangaande virustransport in de aardappelplant bleven hierin onaangeroerd.

\subsection{EIGEN ONDERZOEK}

\subsubsection{Materiaal en methoden}

Voor de proeven, die in dit hoofdstuk zullen worden besproken, werden steeds goedgekeurde pootaardappelen gebruikt, die bovendien na het opkomen werden gecontroleerd op de aanwezigheid van virusziekten. Het gebruikte virus werd op dezelfde wijze in stand gehouden en op de proefplanten geïnoculeerd als werd beschreven aan het begin van hoofdstuk 2. De knollen, die van de proefplanten werden geoogst, sneden wij, tenzij anders vermeld, vlak voor het uitpoten in een zo groot mogelijk aantal ,stukken met oog" (in het vervolg kortheidshalve „ogen" genoemd). De ogen werden dan alle afzonderlijk in een potje gepoot, waarna de eruit opgroeiende planten werden getoetst op de aanwezigheid van X-virus door uitwrijven van het perssap op Gomphrena globosa. Door deze werkwijze werd een nauwkeurig beeld verkregen van de mate van besmetting van de gehele knolopbrengst van elke plant. Bij het doorsnijden van de knollen werd zorg gedragen, dat geen besmetting van een gezonde knol (of deel ervan) door het snijmes plaats kon vinden. Daartoe werd het mes na het afsnijden van elk knolstuk ontsmet. De toetsing van de plantjes geschiedde meestal vrij spoedig na het opkomen, aangezien kleine planten gemakkelijk zijn te hanteren en ook om de mogelijkheid te ontgaan, dat de planten elkaar raakten en daardoor besmetten.

\subsubsection{Verwerking van de gegevens}

In de hoofdstukken 3 en 4 zullen een aantal proeven worden beschreven, waaruit uitgebreide gegevens werden verkregen over de mate van besmetting van de knollen op een gegeven tijdstip na de inoculatie. Deze gegevens verschaffen inlichtingen over de besmetting van elke plant afzonderlijk. In de tabellen, waarin deze gegevens zijn verwerkt, zijn in de meeste gevallen voor 
elke rooidatum de volgende kolommen opgenomen: 1 . Het aantal planten, dat zieke knollen opleverde en het totaal aantal gebruikte proefplanten; 2. Het aantal en percentage (geheel of gedeeltelijk) zieke knollen, betrokken op het totale aantal getoetste knollen, waarbij eventueel is inbegrepen de opbrengst van planten, waarvan in het geheel geen knollen besmet zijn geraakt; 3. Het aantal en percentage zieke ogen betrokken op het totale aantal getoetste ogen, waarbij zijn inbegrepen de ogen van die planten, die geen zieke knollen hebben opgeleverd.

Het zou nu mogelijk zijn geweest, de gegevens over de punten 2 en 3 slechts te betrekken op die planten, welke minstens één geheel of gedeeltelijk zieke knol opleverden. Wij meenden echter, dat de door ons gevolgde wijze van weergeven de voorkeur verdient, daar de percentages zieke knollen en zieke ogen een zo goed mogelijke weergave zijn van de kans op infectie, die een bepaalde groep van planten op een zeker moment heeft. De in de punten 1,2 en 3 vervatte gegevens verschaffen in deze volgorde steeds een beter inzicht in de mate van besmetting van een gehele groep.

Van elke belangrijke proef zijn de gegevens in het aanhangsel in detail vermeld en hieruit kunnen de gegevens van elke zieke plant afzonderlijk worden afgeleid.

\subsubsection{Onderzoek met het ras Bintje in de kas}

Een proef, die zowel nauwkeurige gegevens verschafte over de transportsnelheid, als de daarop volgende mate van besmetting van de knollen, was de volgende. Op 15 maart 1954 werden 100 aardappelknollen (Bintje) gepoot in grote potten. $\mathrm{Na}$ opkomst werden de planten op één stengel gehouden. Ze groeiden op in een onverwarmd warenhuis en gaven een normale groei te zien, waarbij de gerektheid, die in de zomer bij kasplanten opvalt, vrijwel achterwege bleef. Op 22 mei, 68 dagen na het poten, werd van alle planten het jongste, volgroeide blad geïnoculeerd met $X$-virus, afkomstig van aardappel; 2, 3, 4, 5, 6, 7, 8, 9,10 en 11 dagen na de inoculatie werden telkens 10 planten gerooid. Ongeveer midden september werden alle ogen van alle knollen gepoot. Na toetsing van de er uit opgroeiende planten werden de in tabel 9 gegeven resultaten verkregen. Hierin is o.m. weergegeven, in hoeveel planten er enig trans-

TABel 9. Het transport van aardappel X-virus naar de knollen van de aardappel (Bintje) na inoculatie van een topblad.

The translocation of potato virus $X$ to the tubers in she potato (Bintje) after inoculation of a top leaf.

Pootdatum: 15 maart 1954. Datum van inoculatie: 22 mei 1954

Date of planting: 15 March 1954. Date of inoculation: 22 May 1954

Aantal dagen na inoculatie ..... . Number of days after inoculation

Aantal toetsplanten ........ Number of test plants

Aantal planten met zieke knollen . . . Number of plants with diseased tubers

Aantal getoetste ogen . . . . . . . Number of tested eyes

Aantal zjeke ogen . .

Number of diseased eyes

Percentage/Percentage.

\begin{tabular}{|r|r|r|r|r|r|r|r|r|r}
2 & 3 & 4 & 5 & 6 & 7 & 8 & 9 & 10 & 11 \\
10 & 10 & 10 & 10 & 10 & 10 & 10 & 10 & 10 & 10 \\
0 & 0 & 0 & 1 & 3 & 1 & 4 & 2 & 2 & 1 \\
19 & 82 & 94 & 102 & 107 & 87 & 129 & 128 & 118 & 109 \\
0 & 0 & 0 & 4 & 8 & 6 & 9 & 6 & 8 & 3 \\
0 & 0 & 0 & 4 & 7 & 7 & 7 & 5 & 7 & 3
\end{tabular}


TABRL 10. De mate van knolinfectie met betrekking tot de tijdsduur tussen de inoculatie van een topblad met aardappel X-virus en de oogst.

The rate of tuber infection in relation to the interval between the inoculation of a top leaf with potato virus $X$ and the harvest.

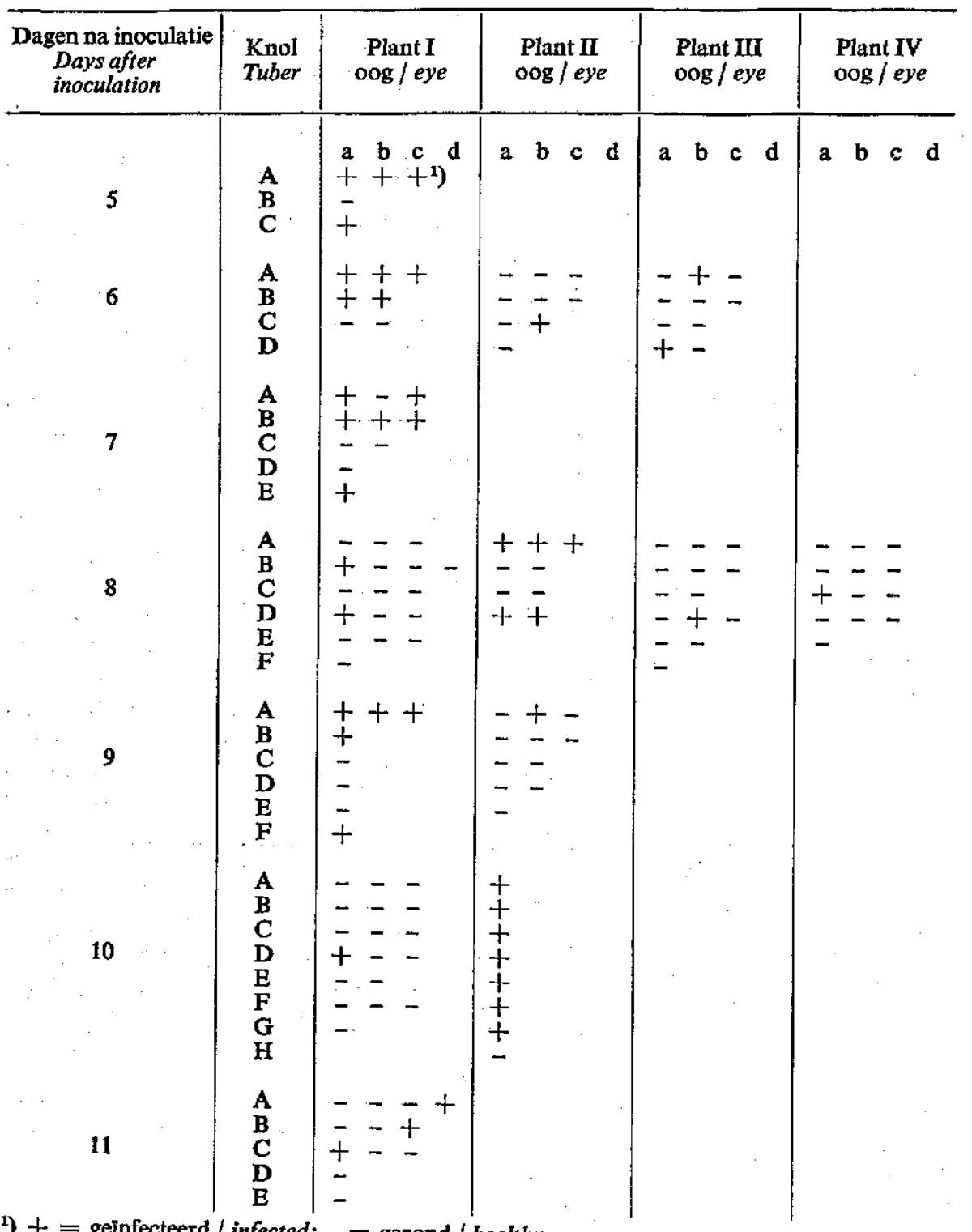

1) $+=$ geinfecteerd / infected; $-=$ gezond / healthy.

port naar de knollen werd geconstateerd. We zien, dat dit over het algemeen in weinig planten het geval was. Na vijf dagen werden de eerste knollen besmet bevonden. Verwacht mocht worden, dat de daarop volgende dagen geleidelijk een groter aantal planten besmette knollen op zou leveren; dit was 
echter niet het geval. Onder de gegeven omstandigheden vindt transport van het virus naar de knollen blijkbaar slechts moeilijk plaats. Ook het aantal en het percentage zieke ogen wijst er op, dat in de toestand, die vijf dagen na de inoculatie was bereikt, in de daarop volgende dagen weinig verandering kwam. Gezien de resultaten van eerder beschreven proeven (BEEMSTER, 1954) is het zeer waarschijnlijk, dat ook hier de planten op het moment van de inoculatie reeds te oud waren om nog een besmetting van de knollen van enige betekenis tengevolge te kunnen hebben.

De volledige gegevens van die planten, die wel besmetting van een of meer knollen te zien hebben gegeven, zijn in tabel 10 gedetailleerd weergegeven. In deze tabel is steeds de grootste knol van een plant aangeduid met $A$, de daaropvolgende met $B$, enz. De ogen van iedere knol zijn aangegeven met a, b, c, d, waarbij a in alle gevallen het topoog aangeeft, dit is dus het oog dat aan de knol het verste van het naveleinde verwijderd is.

De gegevens in tabel 10 demonstreren duidelijk, dat het knollenstelsel van een aardappelplant na primaire infectie met het X-virus slechts ten dele met het $\mathrm{X}$-virus wordt besmet. Dit uit zich in twee feiten: 1 . een knol bezit soms zowel zieke als gezonde ogen, 2 . een aantal knollen is nog geheel gezond gebleven. Deze gegevens doen de vraag rijzen, welke knollen van een plant en welke ogen van een knol het eerst worden besmet. Aan de hand van de gegevens in tabel 10 en de resultaten van enkele nog te bespreken proeven, zullen aan deze vraagstukken aparte paragrafen in hoofdstuk 5 worden gewijd.

\subsubsection{Onderzoek met het ras Bintje in het veld}

Op 25 april 1952 werden 300 knollen van het ras Bintje in het veld gepoot en na opkomst op één stengel gehouden. Op 5 juni daaropvolgend werd begonnen met het uitvoeren van een proef, waarvan in tabel 11 het schema is weergegeven. Uit deze tabel is af te leiden, dat de eerste inoculatie plaats vond 41 dagen na het poten en dat vervolgens telkens een week later een 15-tal planten werd geïnoculeerd. De inoculatie vond plaats op het jongste, volkomen ontwikkelde blad. Het rooien geschiedde bij een gedeelte van de planten drie weken na de inoculatie (A), bij een ander gedeelte vijf weken na de inoculatie (B), terwijl op 21 juli het rooien plaats vond van groepen planten, die op verschillende data waren geïnoculeerd (C); 21 juli is ongeveer de datum, waarop E-pootgoed ge-

TABEL 11. Schema van de veldproef met het aardappelras Bintje.

Design of the field experiment with the potato variety Bintje.

\begin{tabular}{|c|c|c|c|c|}
\hline \multirow{2}{*}{$\begin{array}{c}\text { Datum van } \\
\text { inoculatie } \\
\text { Date of } \\
\text { inoculation }\end{array}$} & \multirow{2}{*}{$\begin{array}{l}\text { Hoogte van de } \\
\text { planten } \\
\text { Height of the } \\
\text { plants at the } \\
\text { moment of } \\
\text { inoculation }\end{array}$} & \multicolumn{3}{|c|}{$\begin{array}{l}\text { Oogst van } 15 \text { planten op } \\
\text { Harvest of } 15 \text { plants on }\end{array}$} \\
\hline & & $\mathbf{A}$ & B & C \\
\hline $\begin{array}{r}5 \text { juni } 1952 \\
12 \text { juni } 1952 \\
19 \text { juni } 1952 \\
26 \text { juni } 1952 \\
3 \text { juli } 1952 \\
10 \text { juli } 1952 \\
17 \text { juli } 1952 \\
24 \text { juli } 1952\end{array}$ & $\begin{array}{l}10-12 \mathrm{~cm} \\
15-23 \mathrm{~cm} \\
28-35 \mathrm{~cm} \\
30-40 \mathrm{~cm} \\
45-60 \mathrm{~cm} \\
45-60 \mathrm{~cm} \\
45-60 \mathrm{~cm} \\
45-60 \mathrm{~cm}\end{array}$ & $\begin{array}{r}26 \text { juni } 1952 \\
3 \text { juli } 1952 \\
10 \text { juli } 1952 \\
17 \text { juli } 1952 \\
24 \text { juli } 1952 \\
31 \text { juli } 1952 \\
7 \text { aug. } 1952 \\
14 \text { aug. } 1952\end{array}$ & $\begin{array}{r}31 \text { juli } 1952 \\
7 \text { aug. } 1952 \\
14 \text { aug. } 1952 \\
21 \text { aug. } 1952 \\
28 \text { aug. } 1952\end{array}$ & 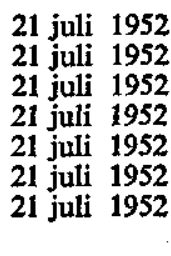 \\
\hline
\end{tabular}


rooid moet zijn. Uit de gegevens omtrent de toestand van ontwikkeling van het gewas op het moment van de inoculatie, zien we, dat voor de eerste maal een inoculatie geschiedde op het moment, dat de planten nog zeer klein waren. Van begin juli af zijn de planten blijkbaar gekomen in een stadium, waarin de lengtegroei van de stengels niet meer van betekenis is.

$\mathrm{Na}$ het rooien werd van iedere plant afzonderlijk de gehele oogst in een papieren zak gedeponeerd en bewaard tot ongeveer 6 maanden na het rooien. Op dat moment hadden de knollen reeds spruiten gevormd en werd van drie knollen van elke plant het stuk van het topeinde gepoot. Deze drie knollen waren respectievelijk de grootste, een middelgrote en de kleinste knol, welke laatste dan ook steeds geheel werd gepoot. De eruit opgroeiende planten werden getoetst op de aanwezigheid van het X-virus door uitwrijven van het perssap op Gomphrena globosa. De toetsing leverde de in tabel 12 gegeven resultaten op.

De resultaten tonen duidelijk aan, dat bij planten, die in een jong stadium worden geïnoculeerd (ineculatiedata 5,12 en 19 juni) het virus drie weken na de inoculatie in $100 \%$ van de gevallen in de knollen kan worden aangetoond.

TABEL 12. Besmetting van de knollen bij het ras Bintje na inoculatie van planten in verschillende stadia van hun ontwikkeling.

Infection of the tubers in the variety Bintje after inoculation of plants in different stages of their development.

Pootdatum: 25 april 1952 / Planting date: 25 April 1952

\begin{tabular}{|c|c|c|c|c|c|c|c|c|c|}
\hline \multirow{2}{*}{$\begin{array}{l}\text { Groep } \\
\text { Group }\end{array}$} & \multirow{2}{*}{$\begin{array}{l}\text { Grootte van de } \\
\text { getoetste knol } \\
\text { Size of the tested } \\
\text { tuber }\end{array}$} & \multicolumn{8}{|c|}{ Inoculatiedatum / Date of inoculation } \\
\hline & & $5 / 6$ & $12 / 6$ & $19 / 6$ & $26 / 6$ & $3 / 7$ & $10 / 7$ & $17 / 7$ & $24 / 7$ \\
\hline \multirow{4}{*}{$\mathbf{A}$} & grootste & $\left.15 / 15^{1}\right)$ & $15 / 15$ & $15 / 15$ & $15 / 15$ & $12 / 15$ & $3 / 15$ & $2 / 15$ & $3 / 15$ \\
\hline & middelgroot $\quad$. & $15 / 15$ & $15 / 15$ & $15 / 15$ & $14 / 15$ & $15 / 15$ & $4 / 15$ & $3 / 15$ & $2 / 15$ \\
\hline & $\begin{array}{l}\text { kleinste } \\
\text { smallest }\end{array}$ & $15 / 15$ & $15 / 15$ & $15 / 15$ & $10 / 15$ & $13 / 15$ & $3 / 15$ & $1 / 15$ & $2 / 15$ \\
\hline & $\begin{array}{l}\text { totaal } \\
\text { total }\end{array} \cdots$ & $45 / 45$ & $45 / 45$ & $45 / 45$ & $39 / 45$ & $40 / 45$ & $10 / 45$ & $6 / 45$ & $7 / 45$ \\
\hline \multirow{4}{*}{ B } & $\begin{array}{l}\text { grootste } . \cdots \\
\text { biggest }\end{array}$ & & & & $12 / 15$ & $15 / 15$ & $9 / 15$ & $6 / 15$ & $8 / 15$ \\
\hline & $\begin{array}{l}\text { middelgroot } \\
\text { medium }\end{array}$ & & & & $14 / 15$ & $15 / 15$ & $12 / 15$ & $4 / 15$ & $6 / 15$ \\
\hline & $\begin{array}{l}\text { kleinste } \\
\text { smallest }\end{array}$ & & & & $13 / 15$ & $14 / 15$ & $11 / 15$ & $4 / 15$ & $2 / 15$ \\
\hline & $\begin{array}{l}\text { totaal } \ldots . . \\
\text { total }\end{array}$ & & & & $39 / 45$ & $44 / 45$ & $32 / 45$ & $14 / 45$ & $16 / 45$ \\
\hline \multirow{4}{*}{ C } & $\underset{\text { biggest }}{\text { grootste }} \ldots$ & $15 / 15$ & $15 / 15$ & $15 / 15$ & $15 / 15$ & $13 / 15$ & $3 / 15$ & $0 / 15$ & \\
\hline & $\begin{array}{l}\text { middelgroot } \\
\text { medium }\end{array}$ & $15 / 15$ & $15 / 15$ & $15 / 15$ & $15 / 15$ & $13 / 15$ & $2 / 15$ & $0 / 15$ & \\
\hline & $\begin{array}{l}\text { kleinste } \\
\text { smallest }\end{array}$ & $15 / 15$ & $15 / 15$ & $15 / 15$ & $15 / 15$ & $10 / 15$ & $1 / 15$ & $0 / 15$ & \\
\hline & $\begin{array}{l}\text { totaal } \\
\text { total }\end{array}$ & $45 / 45$ & $45 / 45$ & $45 / 45$ & $45 / 45$ & $36 / 45$ & $6 / 45$ & $0 / 45$ & \\
\hline
\end{tabular}

1) teller: aantal geinfecteerde knollen; noemer: aantal getoetste knollen.

numerator: number of infected tubers; denominator: number of tested tubers. 
Naarmate de knollen op het moment van de inoculatie ouder zijn, zien we een geleidelijke teruggang van het aantal geïfecteerde knollen. Ook hier komt dus weer duidelijk de reeds in hoofdstuk 2(2.3.2) gesignaleerde ouderdomsresistentie naar voren.

De resultaten van de toetsing van de knollen, die vijf weken na de inoculatie werden gerooid, vertonen eveneens een geleidelijke teruggang in het aantal geinfecteerde knollen, naarmate op een later tijdstip werd geïnoculeerd. Bij vergelijking van de cijfers van drie en vijf weken na de inoculatie valt het op, dat het aantal zieke knollen na vijf weken over het algemeen groter is dan na drie weken. Dit is begrijpelijk voor jong geïnoculeerde planten, maar bij de in een wat later stadium geinnoculeerde planten wijst dit er op, dat de ouderdomsresistentie niet absoluut is, met andere woorden, ook in oudere planten vindt blijkbaar transport van virus naar de knollen plaats, maar in een vertraagd tempo.

De derde groep van planten, nl. die, welke op één datum werden gerooid, geven, zoals verwacht mocht worden, een afdalende reeks te zien in het aantal geïnfecteerde knollen. In dit geval wordt de aard van deze reeks bepaald door twee factoren, $\mathrm{nl}$. het verschil in tijd tussen de inoculatie en het rooien en het verschil in ouderdom van de planten op het moment van de inoculatie. Na het beschouwen van de resultaten van de reeds genoemde twee reeksen, levert deze reeks geen bijzonderheden op. Vermeldenswaard is echter, dat 11 dagen voor de rooidatum geïnoculeerde planten reeds enkele zieke knollen hebben opgeleverd, nl. 6 van de 45 .

Van de groepen planten, die drie en vijf weken na de inoculatie werden gerooid, werden eveneens op de dag van het rooien bladeren getoetst om na te gaan of hierin het $\mathrm{X}$-virus (in aantoonbare hoeveelheid) aanwezig was. Hiertoe werden van iedere plant drie bladeren genomen, nl, een van de top, een van het midden en een van de basis. De toetsing geschiedde met Gomphrena globosa en de resultaten hiervan, die als een anvulling van de in paragraaf 2.3 .4 besproken proef kunnen worden beschouwd, zijn gegeven in tabel 13.

We zien, dat het $X$-virus na de inoculatie van een blad in de top van een jonge plant drie weken na de inoculatie in vrijwel alle bladeren aantoonbaar is (toetsing op 26 juni). Duidelijk blijkt echter dat, naarmate de plant ouder is op het moment van de inoculatie, het virus minder snel in aantoonbare concentratie aanwezig is in de bladeren beneden het geïnoculeerde blad. Gedurende de periode, waarin de plant de lengtegroei nog niet heeft voltooid, vindt het transport van het virus naar de topbladeren nog vrij gemakkelijk plaats.

Uit tabel 11 is op te maken, dat de planten omstreeks 3 juli haar lengtegroei hebben voltooid. Tussen 3 en 10 juli is, zoals uit tabel 12 volgt, het virustransport aanzienlijk verminderd. Het ligt voor de hand deze vermindering in verband te brengen met de beëindiging van de lengtegroei. Deze opvatting vindt steun in gegevens van tabel 13, waaruit blijkt, dat omstreeks terzelfdertijd het virus ook veel moeilijker aantoonbaar wordt in de bladeren beneden het geinoculeerde blad dan in die bij de in een jonger stadium geïnoculeerde planten.

Zoals ook reeds in 2.3.4 werd opgemerkt is het feit, dat geen virus in een blad wordt aangetoond, geen bewijs, dat er geen virus in aanwezig is. Het is in dit geval dus niet geheel juist te spreken over transport, waar we met de mate virusvermeerdering te maken hebben. 
TABEL 13. De aanwezigheid van aardappel $\mathrm{X}$-virus in bladeren op verschillende hoogten van de stengel van aardappelplanten, die in verschillende stadia van hun ontwikkeling in de top waren geinoculeerd.

The presence of potato virus $X$ in leaves at different levels of potato plants inoculated in the top in different stages of their development.

\begin{tabular}{|c|c|c|c|c|}
\hline \multirow{2}{*}{$\begin{array}{c}\text { Inoculatiedatum } \\
\text { Date of } \\
\text { inoculation }\end{array}$} & \multirow{2}{*}{$\begin{array}{l}\text { Datum van } \\
\text { toetsing } \\
\text { Date of testing }\end{array}$} & \multicolumn{3}{|c|}{$\begin{array}{l}\text { Drie weken na de inoculatie } \\
\text { Three weeks after inoculation }\end{array}$} \\
\hline & & top / top & midden / middle & basis / base \\
\hline $\begin{array}{r}5 \text { juni } 1952 \\
12 \text { juni } 1952 \\
19 \text { juni } 1952 \\
26 \text { juni } 1952 \\
3 \text { juli } 1952 \\
10 \text { juli } 1952 \\
17 \text { juli } 1952 \\
24 \text { juli } 1952\end{array}$ & $\begin{array}{r}26 \text { juni } 1952 \\
3 \text { juli } 1952 \\
10 \text { juli } 1952 \\
17 \text { juli } 1952 \\
24 \text { juli } 1952 \\
31 \text { juli } 1952 \\
7 \text { aug. } 1952 \\
14 \text { aug. } 1952\end{array}$ & $\begin{array}{l}\left.15 / 15^{1}\right) \\
15 / 15 \\
14 / 15 \\
15 / 15(6) \\
13 / 15(14) \\
13 / 15(15) \\
13 / 15(15) \\
12 / 15(15)\end{array}$ & $\begin{array}{l}\left.15 / 15(15)^{2}\right) \\
15 / 15(15) \\
15 / 15(15) \\
12 / 15(9) \\
6 / 15(1) \\
1 / 15 \\
1 / 15 \\
1 / 15\end{array}$ & $\begin{array}{r}13 / 15 \\
12 / 15 \\
6 / 15 \\
6 / 15 \\
12 / 15 \\
3 / 15 \\
0 / 15 \\
1 / 15\end{array}$ \\
\hline & & \multicolumn{3}{|c|}{$\begin{array}{l}\text { Vijf weken na de inoculatie } \\
\text { Five weeks after inoculation }\end{array}$} \\
\hline $\begin{array}{r}26 \text { juni } 1952 \\
3 \text { juli } 1952 \\
10 \text { juli } 1952 \\
17 \text { juli } 1952 \\
24 \text { juli } 1952\end{array}$ & $\begin{array}{r}31 \text { juli } 1952 \\
7 \text { aug. } 1952 \\
14 \text { aug. } 1952 \\
21 \text { aug. } 1952 \\
28 \text { aug. } 1952\end{array}$ & $\begin{array}{l}15 / 15(7) \\
13 / 15(11) \\
15 / 15(15) \\
13 / 15(15) \\
5 / 7 \quad(7)\end{array}$ & $\begin{array}{l}10 / 15(8) \\
15 / 15(4) \\
1 / 15 \\
3 / 15 \\
1 / 7\end{array}$ & $\begin{array}{l}2 / 15 \\
4 / 15 \\
2 / 15 \\
1 / 15 \\
1 / 7\end{array}$ \\
\hline \multicolumn{5}{|c|}{$\begin{array}{l}\text { 1) teller: aantal bladeren, waarin virus werd aangetoond; noemer: aantal getoetste bladeren. } \\
\text { numerator: number of leaves in which virus was detected; denominator: number of tested } \\
\text { leaves. } \\
\text { 2) tussen haakjes: het aantal bladeren in de betrokken groep, waarop het X-virus in de plant } \\
\text { was gebracht. } \\
\text { in brackets: the number of leaves in the group indicated, in which virus } X \text { had been introduced } \\
\text { into the plants. }\end{array}$} \\
\hline
\end{tabular}

\subsubsection{Onderzoek met verschillende rassen in de kas}

Teneinde na te gaan of het transport van het X-virus bij verschillende aardappelrassen verschillen vertoont, werden hierover een tweetal proeven uitgevoerd. Op 5 juni 1954 werden van de rassen Bintje, Eigenheimer, Voran en Bevelander elk 40 knollen gepoot in grote potten, die in een warenhuis werden ondergebracht. Op 13 juli daaropvolgend werden van elk ras 20 planten (die op één stengel waren gehouden) geïnoculeerd op het jongste, volkomen ontwikkelde blad. Respectievelijk 2, 4, 6, 8 en 10 dagen na de inoculatie werden van elk ras telkens vier planten gerooid. Twee weken na de eerste inoculatie, op 27 juli, werden de nog resterende planten van elk ras op dezelfde wijze geïnoculeerd en ook van deze groep werden $2,4,6,8$ en 10 dagen later telkens vier planten gerooid. $\mathrm{Na}$ het rooien werd de opbrengst van iedere plant afzonderlijk bewaard. Op het moment, dat de knollen een begin van spruitvorming vertoonden, werd elke $\mathrm{knol}$ in een zo groot mogelijk aantal ogen gesneden en ieder oog afzonderlijk in een potje gepoot.

De volledige resultaten van de toetsing zijn weergegeven in het aanhangsel, proef 3.3.5.1. Opgemerkt moet worden, dat een enkele maal per vergissing vijf in plaats van vier planten werden gerooid. Bovendien werden enkele reserveplanten mede gerooid op de tiende dag na de inoculatie van de tweede groep. 
TABeL. 14. Het transport van aardappel $X$-virus van het geïnoculeerde blad naar de knollen bij verschillende aardappelrassen.

The translocation of potato virus $X$ from the inoculated leaves to the tubers in different potato varieties.

\begin{tabular}{|c|c|c|c|c|c|c|c|}
\hline \multirow{3}{*}{$\underset{\text { Variety }}{\operatorname{Ras}}$} & \multicolumn{7}{|c|}{ Pootdatum 5 juni 1954 / Planting date: 5 June 1954} \\
\hline & \multirow{2}{*}{$\begin{array}{l}\text { Dagen na } \\
\text { inoculatie } \\
\text { Days affer } \\
\text { inoculation }\end{array}$} & \multicolumn{3}{|c|}{$\begin{array}{c}\text { Inoculatie op } 13 \text { juli } \\
\text { Inoculation on } 13 \text { July } \\
\text { Infectie van de / Infection of the }\end{array}$} & \multicolumn{3}{|c|}{$\begin{array}{c}\text { Inoculatie op } 27 \text { juli } \\
\text { Inoculation on } 27 \text { July } \\
\text { Infectie van de / Infection of the }\end{array}$} \\
\hline & & $\begin{array}{c}\text { planten } \\
\text { plants }\end{array}$ & $\begin{array}{c}\text { knollen } \\
\text { tubers }\end{array}$ & $\begin{array}{l}\text { ogen } \\
\text { eyes }\end{array}$ & $\begin{array}{c}\text { planten } \\
\text { plants }\end{array}$ & $\begin{array}{c}\text { knollen } \\
\text { tubers }\end{array}$ & $\begin{array}{l}\text { ogen } \\
\text { eyes }\end{array}$ \\
\hline Bintje & $\begin{array}{r}2 \\
4 \\
6 \\
8 \\
10\end{array}$ & $\begin{array}{l}\left.0 / 4^{1}\right) \\
1 / 4 \\
2 / 4 \\
4 / 4 \\
4 / 4\end{array}$ & $\begin{array}{l}\left.0 / 20^{2}\right) 0 \% \\
2 / 28 \quad 7 \% \\
2 / 27 \quad 7 \% \\
8 / 2433 \% \\
8 / 1457 \%\end{array}$ & 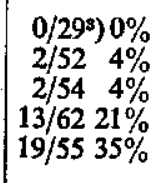 & $\begin{array}{l}0 / 4 \\
1 / 4 \\
1 / 4 \\
0 / 4 \\
1 / 5\end{array}$ & $\begin{array}{ll}0 / 22 & 0 \% \\
1 / 19 & 5 \% \\
1 / 27 & 4 \% \\
0 / 26 & 0 \% \\
1 / 36 & 3 \%\end{array}$ & $\begin{array}{ll}0 / 82 & 0 \% \\
1 / 88 & 1 \% \\
1 / 111 & 1 \% \\
0 / 104 & 0 \% \\
1 / 157 & 1 \%\end{array}$ \\
\hline Eigenheimer & $\begin{array}{r}2 \\
4 \\
6 \\
8 \\
10\end{array}$ & $\begin{array}{l}0 / 4 \\
1 / 4 \\
2 / 4 \\
4 / 4 \\
4 / 4\end{array}$ & $\begin{array}{rr}0 / 18 & 0 \% \\
1 / 29 & 3 \% \\
4 / 19 & 21 \% \\
13 / 19 & 68 \% \\
17 / 23 & 74 \%\end{array}$ & $\begin{array}{rr}0 / 27 & 0 \% \\
1 / 44 & 2 \% \\
4 / 54 & 7 \% \\
29 / 54 & 54 \% \\
45 / 64 & 70 \%\end{array}$ & $\begin{array}{l}0 / 4 \\
0 / 4 \\
1 / 4 \\
0 / 4 \\
2 / 5\end{array}$ & $\begin{array}{ll}0 / 19 & 0 \% \\
0 / 17 & 0 \% \\
1 / 15 & 7 \% \\
0 / 23 & 0 \% \\
2 / 28 & 7 \%\end{array}$ & $\begin{array}{ll}0 / 66 & 0 \% \\
0 / 69 & 0 \% \\
2 / 69 & 3 \% \\
0 / 90 & 0 \% \\
2 / 123 & 2 \%\end{array}$ \\
\hline Voran & $\begin{array}{r}2 \\
4 \\
6 \\
8 \\
10\end{array}$ & $\begin{array}{l}0 / 3 \\
0 / 5 \\
0 / 3 \\
2 / 3 \\
4 / 4\end{array}$ & $\begin{array}{lr}0 / 9 & 0 \% \\
0 / 20 & 0 \% \\
0 / 16 & 0 \% \\
4 / 11 & 36 \% \\
8 / 19 & 42 \%\end{array}$ & $\begin{array}{rr}0 / 16 & 0 \% \\
0 / 44 & 0 \% \\
0 / 48 & 0 \% \\
5 / 36 & 14 \% \\
12 / 58 & 21 \%\end{array}$ & $\begin{array}{l}0 / 4 \\
0 / 4 \\
0 / 4 \\
0 / 4 \\
1 / 5\end{array}$ & $\begin{array}{ll}0 / 12 & 0 \% \\
0 / 17 & 0 \% \\
0 / 8 & 0 \% \\
0 / 13 & 0 \% \\
1 / 16 & 6 \%\end{array}$ & $\begin{array}{ll}0 / 39 & 0 \% \\
0 / 73 & 0 \% \\
0 / 44 & 0 \% \\
0 / 57 & 0 \% \\
1 / 78 & 1 \%\end{array}$ \\
\hline velander & $\begin{array}{r}2 \\
4 \\
6 \\
8 \\
10\end{array}$ & $\begin{array}{l}0 / 4 \\
0 / 4 \\
1 / 4 \\
2 / 4 \\
4 / 4\end{array}$ & $\begin{array}{rr}0 / 13 & 0 \% \\
0 / 24 & 0 \% \\
2 / 21 & 10 \% \\
7 / 19 & 37 \% \\
16 / 23 & 70 \%\end{array}$ & $\begin{array}{rr}0 / 16 & 0 \% \\
0 / 35 & 0 \% \\
5 / 52 & 10 \% \\
15 / 56 & 27 \% \\
47 / 66 & 71 \%\end{array}$ & $\begin{array}{l}0 / 4 \\
0 / 4 \\
0 / 4 \\
4 / 4 \\
4 / 4\end{array}$ & $\mid \begin{array}{rr}0 / 16 & 0 \% \\
0 / 12 & 0 \% \\
0 / 23 & 0 \% \\
9 / 17 & 53 \% \\
15 / 20 & 75 \%\end{array}$ & $\begin{array}{rr}0 / 69 & 0 \% \\
0 / 55 & 0 \% \\
0 / 87 & 0 \% \\
16 / 63 & 25 \% \\
50 / 77 & 65 \%\end{array}$ \\
\hline
\end{tabular}

1) teller: aantal planten met geīnfecteerde knollen / numerator: number of plants with infected tubers.

noemer: aantal toetsplanten/denominator: number of test plants.

2) teller: aantal geinfecteerde knollen / numerator: number of infected tubers. noemer: aantal getoetste knollen / denominator: number of tested tubers.

3) teller: aantal geinfecteerde ogen / numerator: number of infected eyes. noemer: aantal getoetste ogen / denominator: number of tested eyes.

In tabel 14 zijn de resultaten samengevat weergegeven. In deze tabel zijn opgenomen: het aantal proefplanten en het aantal planten, waarin transport naar de knollen heeft plaats gevonden; het aantal getoetste en het aantal en percentage geïnfecteerde knollen van elke groep en het aantal en percentage geïnfecteerde ogen per groep. Dit laatste percentage geeft het meest juiste beeld van de mate, waarin transport van virus naar de knollen heeft plaats gehad. Uit de volledige gegevens (zie aanhangsel) blijkt $\mathrm{nl}$., dat het veelvuldig voorkomt, dat van een bepaalde knol slechts een klein gedeelte van het totaal aantal ogen besmet is. De cijfers, die het percentage zieke knollen aangeven, zijn gebaseerd op het feit of een knol al dan niet tenminste één ziek oog heeft opgeleverd. In de meeste gevallen zien we dan ook, vooral wanneer de inoculatie recent heeft plaats gevonden, dat het percentage zieke knollen groter is dan het per- 


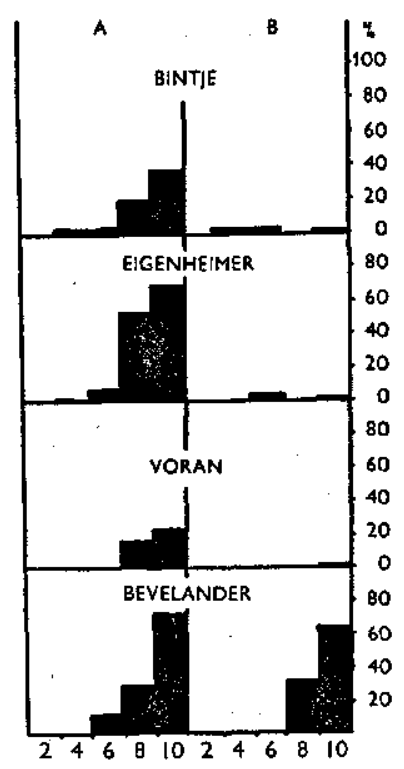

FrG. 3. De percentages van de besmetting der ogen met X-virus $2,4,6,8$ en 10 dagen na de inoculatie bij de rassen Bintje, Eigenheimer, Voran en Bevelander na inoculatie resp. 38 (A) en 52 dagen (B) na het poten.

The percentages of infection of the eyes with virus $X$ in the varieties Bintje, Eigenheimer, Voran and Bevelander $2,4,6,8$ and 10 days after inoculation $38(A)$ and 52 days $(B)$ after planting respectively.

centage zieke ogen. Welk cijfer de meest praktische bruikbaarheid bezit, is afhankelijk van het antwoord op de vraag of een besmetting van een gedeelte van een knol na het poten ervan aanleiding zal geven tot een geheel zieke aardappelplant. Dit vraagstuk zal nog nader worden besproken in hoofdstuk 5. Voor meer theoretische beschouwingen is het juister, gebruik te maken van de cijfers over de besmetting van de ogen, wat dan ook bij de nog te bespreken proeven steeds zal worden gedaan.

We zien uit de cijfers van tabel 14 en uit figuur 3, waarin de gegevens van de ogen in een diagram zijn weergegeven, dat bij de rassen Bintje en Eigenheimer reeds vier dagen na de inoculatie op 13 juli virus in de knollen werd aangetroffen; bij Bevelander was dit het geval na zes dagen en bij Voran na acht dagen. In het algemeen kan worden gezegd, dat het transport eerst na acht dagen betekenis krijgt. Uit de cijfers, die de percentages na acht en tien dagen aangeven, is te zien, dat de rassen Eigenheimer en Bevelander het intensiefste transport te zien hebben gegeven. Hoewel bij Bintje dus wel kort na de inoculatie enig virus naar de knollen werd getransporteerd, blijkt, dat bij dit ras het virus niet snel tot een zo intensieve verspreiding naar en in de knollen is gekomen als bij Eigenheimer en Bevelander. Het meest valt echter het geringe percentage bij het ras Voran op.

De resultaten, verkregen na de inoculatie op 27 juli laten zien, dat de rassen Bintje, Eigenheimer en Voran zo goed als geen transport binnen 10 dagen te zien hebben gegeven. Bevelander vertoont echter vrijwel geen verschil met de resultaten, verkregen na de inoculatie op 13 juli. De ouderdomsresistentie wordt 
in deze proef weer duidelijk gedemonstreerd bij de eerstgenoemde drie rassen, bij Bevelander is hiervan echter geen sprake.

Daar de bovenbeschreven proef slechts werd voortgezet tot en met tien dagen na de inoculatie, werd in 1955 de proef gedeeltelijk herhaald, waarbij gedurende een langere periode na de inoculatie periodiek werd gerooid. Deze proef voerden wij voornamelijk uit om de onderlinge verschillen tussen de verschillende rassen nogmaals na te gaan en om te zien of langere tijd na de inoculatie nog steeds zowel zieke als gezonde knollen aan een plant worden aangetroffen. De proef werd ditmaal in de herfst uitgevoerd, eveneens in een warenhuis, dat niet verwarmd was. De resultaten van deze proef zijn dus niet geheel vergelijkbaar met die van de eerste. Op 1 september 1955 werden van dezelfde vier rassen elk 60 knollen gepoot. Van de op één stengel gehouden planten werd op 12 oktober een jong, volkomen ontwikkeld blad in de top van de planten met $\mathrm{X}$-virus geinoculeerd. Drie dagen na de inoculatie werden vijf planten van elk ras gerooid, vervolgens telkens vijf planten respectievelijk $5,7,10,12,14,16,19,21$ en 23 dagen na de inoculatie. Een aantal planten had te lijden van Phytophthora-aantasting, waardoor deze niet konden worden gebruikt. Dit had tot gevolg, dat op de laatste rooidatum niet van alle planten een voldoende aantal aanwezig was. Enkele reserveplanten werden pas 43 dagen na de inoculatie gerooid. De volledige gegevens van deze proef zijn gegeven in het anhangsel, proef 3.3.5.2. Tabel 15 geeft een beknopte samenvatting hiervan. Hierin zijn per rooidatum van elk ras het aantal getoetste en het aantal en percentage zieke ogen per groep vermeld.

Uit de volledige gegevens en uit tabel 15 is op te maken, dat het aantal ogen, dat per plant werd verkregen, zeer veel kleiner was dan bij de vorige proef. Dit

TABel 15. Het transport van aardappel $X$-virus naar de knollen bij verschillende aardappelrassen.

The translocation of potato virus $X$ to the tubers in different potato varieties.

\begin{tabular}{|c|c|c|c|c|c|c|c|c|}
\hline \multirow{3}{*}{$\begin{array}{l}\text { Dagen na } \\
\text { inoculatie } \\
\text { Days after } \\
\text { inoculation }\end{array}$} & \multicolumn{8}{|c|}{$\begin{array}{l}\text { Pootdatum: } 1 \text { september } 1955 \text { / Date of planting: 1 September } 1955 \\
\text { Inoculatiedatum: } 12 \text { oktober } 1955 \text { / Date of inoculation: } 12 \text { October } 1955\end{array}$} \\
\hline & \multicolumn{2}{|c|}{ Bintje } & \multicolumn{2}{|c|}{ Eigenheimer } & \multicolumn{2}{|c|}{ Voran } & \multicolumn{2}{|c|}{ Bevelander } \\
\hline & $\begin{array}{l}\text { Aantal } \\
\text { Number }\end{array}$ & $\%$ & $\begin{array}{l}\text { Aantal } \\
\text { Number }\end{array}$ & $\%$ & $\begin{array}{l}\text { Aantal } \\
\text { Number }\end{array}$ & $\%$ & $\begin{array}{l}\text { Aantal } \\
\text { Number }\end{array}$ & $\%$ \\
\hline $\begin{array}{r}3 \\
5 \\
7 \\
10 \\
12 \\
14 \\
16 \\
19 \\
21 \\
23 \\
43\end{array}$ & $\begin{array}{c}\left.0 / 18^{1}\right) \\
0 / 15 \\
0 / 20 \\
6 / 25 \\
4 / 15 \\
5 / 16 \\
8 / 15 \\
14 / 21 \\
14 / 25 \\
20 / 23 \\
16 / 28\end{array}$ & $\begin{array}{r}0 \\
0 \\
0 \\
24 \\
27 \\
31 \\
53 \\
67 \\
56 \\
87 \\
57\end{array}$ & $\begin{array}{r}0 / 19 \\
1 / 30 \\
3 / 26 \\
4 / 29 \\
12 / 26 \\
8 / 30 \\
13 / 32 \\
26 / 28 \\
33 / 42 \\
9 / 17 \\
9 / 12\end{array}$ & $\begin{array}{r}0 \\
3 \\
12 \\
14 \\
46 \\
27 \\
41 \\
93 \\
79 \\
53 \\
75\end{array}$ & $\begin{array}{l}0 / 10 \\
0 / 17 \\
0 / 19 \\
0 / 17 \\
3 / 22 \\
2 / 25 \\
2 / 30 \\
3 / 32 \\
8 / 33 \\
1 / 43 \\
36 / 84\end{array}$ & $\begin{array}{r}0 \\
0 \\
0 \\
0 \\
14 \\
8 \\
7 \\
9 \\
24 \\
2 \\
43\end{array}$ & $\begin{array}{l}0 / 11 \\
0 / 10 \\
0 / 16 \\
0 / 13 \\
0 / 20 \\
0 / 18 \\
\left.5 / 21^{2}\right) \\
0 / 17 \\
2 / 22 \\
4 / 24 \\
-\end{array}$ & $\begin{array}{r}0 \\
0 \\
0 \\
0 \\
0 \\
0 \\
24 \\
0 \\
9 \\
17 \\
-\end{array}$ \\
\hline
\end{tabular}

1) teller: aantal geïnfecteerde ogen / numerator: number of infected eyes. noemer: aantal getoetste ogen / denominator: number of tested eyes.

2) van één plant waren alle vijf knolletjes geïnfecteerd, waarschijnlijk was deze plant secundair besmet.

all five tubers of one plant were infected, this plant was probably secondarily infected. 
feit werd veroorzaakt door de omstandigheid, dat deze proef werd uitgevoerd op een later tijdstip (pootdatum bij deze proef 1 september, bij de vorige 5 juni). De knolgroei blijkt dus in de herfst veel trager dan in de zomermaanden te zijn. Daar het tijdstip van de inoculatie bij beide proeven vrijwel gelijk werd gekozen (bij deze proef 41 dagen na het poten, bij de vorige 38 ) en de planten in beide gevallen in absolute zin dus ongeveer even oud waren op het moment van de inoculatie, kunnen de gevonden verschillen grotendeels worden toegeschreven aan de verschillen in uitwendige omstandigheden. Deze worden gevormd door verschillende factoren, zoals lichtintensiteit, temperatuur en daglengte. Uit de resultaten blijkt, dat bij Bintje en Eigenheimer het transport naar de knollen het intensiefst is geweest. Van deze beide rassen is bij Eigenheimer het transport iets intensiever geweest dan bij Bintje, wat ook bij de eerstbeschreven proef het geval was. Bij de rassen Voran en Bevelander vond over het geheel genomen slechts een matig transport van het virus plaats; bij deze rassen werd respectievelijk pas 14 en 16 dagen na de inoculatie voor de eerste maal virus in de knollen aangetoond. We zien, dat bij deze twee rassen het transport weinig intensief is geweest, daar, waar wel transport plaats vond, nog slechts weinig ogen werden besmet. Duidelijk is dit gedemonstreerd bij Voran, van welk ras 43 dagen na de inoculatie nog acht planten werden gerooid. Deze planten vertoonden alle transport naar de knollen, terwijl toch slechts 36 van de 84 getoetste ogen ziek bleken te zijn. We kunnen in dit gegeven tevens een bewijs zien, dat het geringe percentage zieke ogen, dat aanvankelijk bij Voran werd gevonden, niet kan worden toegeschreven aan de mogelijkheid, dat de inoculatie niet was geslaagd.

Vergelijken we de resultaten van de twee uitgevoerde proeven, dan blijkt, dat de algemene lijn, die aanwezig was in de eerste proef voor een belangrijk deel ook in de tweede proef aanwijsbaar is. In beide proeven vertoont Eigenheimer het intensiefste transport. Laten we Bevelander even buiten beschouwing, dan vertonen de rassen Bintje en Voran in beide proeven hetzelfde beeld ten opzichte van Eigenheimer, nl. bij Voran een zeer gering transport, terwijl Bintje als het ware een tussenschakel vormt tussen Eigenheimer en Voran. De resultaten met Bevelander vertonen daarentegen een volkomen afwijkend beeld. In de eerste próf vond bij dit ras een zeer intensief transport plaats, in de tweede proef zien we echter een zeer gering transport, vergelijkbaar met dat bij Voran. Met de thans ter beschikking staande gegevens is het resultaat met Bevelander niet te verklaren. Een mogelijke verklaring is, dat de fysiologisch nog zeer jonge Bevelander betrekkelijk weinig transport in benedenwaartse richting vertoont. Deze hypothese vindt enige steun bij de in 2.3 .3 beschreven proef (zie fig. 2), waarbij transport naar de top van de plant gemakkelijk geschiedde bij planten, die nog niet tot knolvorming waren gekomen. Aangetoond werd toen echter niet, dat geen transport in benedenwaartse richting had plaats gevonden. Daar bovendien meermalen is gebleken, dat bij Bintje een sterk transport naar de knollen kan plaats vinden, ook in zeer jonge planten, is het trage transport bij Bevelander in de tweede proef niet gemakkelijk te verklaren.

\subsubsection{Onderzoek met verschillende rassen in het veld}

In 1954 werd te Wageningen in het veld een proef uitgevoerd aangaande het transport van X-virus, waarin de rassen Bevelander en Bintje werden betrokken. De proef omvatte van elk ras 250 planten, warvan de knollen op 25 april 
werden gepoot en na opkomst op één stengel werden gehouden. Toen bleek, dat de knolvorming een aanvang had genomen, werd van de beide rassen elk een groep van 85 planten geïnoculeerd. Dit geschiedde op 25 juni, waarbij een van de topbladeren in haar geheel werd geïnoculeerd. Van elk ras rooiden wij daarna telkens vijf planten van de derde dag af tot en met de 23 e dag na de inoculatie, zoals uit tabel 16 is op te maken. Op 2 en 9 juli daaropvolgend, respectievelijk één en twee weken na de inoculatie van de eerste groep, werden nogmaals respectievelijk 85 en 80 planten van elk ras geïnoculeerd, van welke groepen eveneens van de derde dag af telkens vijf planten werden gerooid (zie tabel.16). Na het rooien.werd de oogst van elke plant afzonderlijk bewaard. In mei, juni en juli 1955 werden van elke plant drie knollen getoetst, waarbij de in tabel 16 weergegeven resultaten werden verkregen. In deze tabel is aangegeven bij hoeveel planten tenminste één geïnfecteerde knol werd gevonden, terwijl tevens tussen haakjes is vermeld, hoeveel knollen van de planten, die minstens één zieke knol opleverden, waren geïnfecteerd.

Naar aanleiding van de resultaten, die aangaande het tijdstip van de knolbesmetting weinig positieve uitspraken toelaten, kunnen de volgende opmerkingen worden gemaakt. Onder de gegeven omstandigheden heeft weinig virustransport naar de knollen plaats gevonden. Dit zou kunnen worden toegeschre-

TABEL 16. Het transport van aardappel X-virus bij de rassen Bintje en Bevelander in het veld. The translocation of potato virus $X$ in the varieties Bintje and Bevelander in the field.

\begin{tabular}{|c|c|c|c|c|c|c|}
\hline \multirow{4}{*}{$\begin{array}{l}\text { Dagen na } \\
\text { inoculatie } \\
\text { Days after } \\
\text { inoculation }\end{array}$} & \multicolumn{6}{|c|}{ Pootdatum: 25 april 1954 / Date of planting: 25 April 1954} \\
\hline & \multicolumn{3}{|c|}{ Bintje } & \multicolumn{3}{|c|}{ Bevelander } \\
\hline & \multicolumn{6}{|c|}{ Inoculatiedatum / Date of inoculation } \\
\hline & 25 juni & 2 juli & 9 juli & 25 juni & 2 juli & 9 juli \\
\hline 3 & $\left.0 / 4^{x}\right)$ & $0 / 5$ & $0 / 5$ & $0 / 3$ & $0 / 5$ & $0 / 5$ \\
\hline 4 & $0 / 5$ & $0 / 5$ & $0 / 5$ & $0 / 4$ & $0 / 4$ & $0 / 5$ \\
\hline 5 & & $0 / 5$ & $0 / 5$ & $0 / 4$ & $0 / 5$ & $0 / 5$ \\
\hline 6 & $\left.1 / 5(1 / 3)^{2}\right)$ & $1 / 5(1 / 3)$ & $0 / 5$ & $0 / 4$ & $0 / 5$ & $0 / 5$ \\
\hline 7 & $0 / 5$ & $0 / 5$ & $0 / 5$ & $0 / 4$ & $0 / 5$ & $0 / 5$ \\
\hline 8 & $0 / 4$ & & & $0 / 4$ & & \\
\hline 10 & $0 / 4$ & $1 / 5(1 / 3)$ & $0 / 5$ & $0 / 5$ & $0 / 5$ & $0 / 5$ \\
\hline 11 & $0 / 5$ & $0 / 5$ & $0 / 5$ & $0 / 4$ & $0 / 5$ & $0 / 5$ \\
\hline 12 & & $0 / 5$ & $0 / 5$ & $1 / 5(1 / 3)$ & $1 / 5(1 / 3)$ & $0 / 5$ \\
\hline 13 & $1 / 5(1 / 3)$ & $0 / 4$ & $0 / 5$ & $0 / 4$ & $0 / 5$ & $0 / 5$ \\
\hline 14 & $1 / 5(3 / 3)$ & $0 / 4$ & $0 / 5$ & $1 / 5(2 / 3)$ & $0 / 5$ & $0 / 5$ \\
\hline 15 & & $1 / 5(1 / 2)$ & $\begin{array}{l}0 / 4 \\
0 / 5\end{array}$ & & $0 / 5$ & $\begin{array}{l}0 / 5 \\
0 / 5\end{array}$ \\
\hline $\begin{array}{l}17 \\
18\end{array}$ & $\begin{array}{l}2 / 5(5 / 6) \\
1 / 5(1 / 3)\end{array}$ & $\begin{array}{l}1 / 5(1 / 3) \\
0 / 5\end{array}$ & $0 / 5$ & $2 / 5(4 / 6)$ & $0 / 4$ & $0 / 5$ \\
\hline $\begin{array}{l}19 \\
19\end{array}$ & $1 / 5(1 / 3)$ & $0 / 5$ & $0 / 5$ & $0 / 4$ & & $0 / 5$ \\
\hline 20 & & $1 / 5(3 / 3)$ & $0 / 4$ & $0 / 5$ & $0 / 5$ & $0 / 1$ \\
\hline 21 & $0 / 5$ & $1 / 5(1 / 3)$ & $0 / 4$ & $0 / 5$ & $0 / 5$ & $0 / 1$ \\
\hline $\begin{array}{l}22 \\
24\end{array}$ & $1 / 5(3 / 3)$ & $\begin{array}{l}1 / 5(3 / 3) \\
0 / 3\end{array}$ & & & $3 / 4(6 / 9)$ & \\
\hline
\end{tabular}

1) teller: aantal planten met geinfecteerde knollen / numerator: number of plants with infected

tubers.
noemer: aantal getoetste planten / denominator: number of tested plants.

2) tussen haakjes / in brackets: teller: aantal geïnfecteerde knollen/ numerator: number of

infected tubers.
noemer: aantal getoetste knollen van planten met geinfecteerde knollen/denominator: number of tested tubers of plants with infected tubers. 
ven aan het feit, dat de ouderdomsresistentie hier reeds bij alle groepen van invloed is geweest. We zien, dat na de laatste inoculatie, op 9 juli, bij geen der beide rassen zieke knollen werden gevonden, terwijl na de beide eerste inoculaties slechts sporadisch geïnfecteerde knollen voorkwamen en wel ongeveer 10 of meer dagen na de inoculatie. Slechts in een enkel geval werd bij Bintje een geïnfecteerde knol na zes dagen gevonden. Uit de tussen haakjes geplaatste cijfers blijkt wel, dat ook bij deze proef zowel zieke als gezonde knollen aan één plant werden aangetroffen.

\subsection{SAMENVATTING EN BESPREKING VAN DE RESULTATEN}

De resultaten van de in dit hoofdstuk beschreven proeven tonen aan, dat de variabiliteit in het tijdsverloop tussen de inoculatie en de besmetting van de knollen zeer groot is. Tussen de planten in één enkele proef treden soms reeds aanzienlijke verschillen op: terwijl enkele planten op een bepaalde rooidatum weinig of geen infectie van de knollen te zien geven, is van andere planten op dezelfde rooidatum reeds een groot deel van de knollen geïnfecteerd. Toch krijgen we door het periodiek rooien van b.v. vijf planten per rooidatum over het algemeen een goed beeld van het verloop van de knolbesmetting en heeft het individuele gedrag per plant geen belangrijke invloed op dit algemene beeld, zoals is te zien uit het veelal regelmatige verloop van de cijfers, die de besmetting op een aantal verschillende rooidata aangeven. Het is niet geheel duidelijk, waardoor de variabiliteit wordt bepaald; waarschijnlijk speelt het toeval een belangrijke rol. Een andere mogelijkheid is, dat het geïnoculeerde blad bij de ene plant in een gunstiger fysiologische conditie verkeert om een optimaal transport tot stand te brengen dan het andere, hoewel bij de inoculatie steeds zo gelijkmatig mogelijke bladeren werden gekozen.

Van geheel andere aard zijn de verschillen tussen de resultaten van de verschillende proeven. Reeds herhaaldelijk werd geconstateerd, dat in een bepaalde proef het virustransport in oude planten veel minder snel en minder intensief verliep dan bij jonge. Deze constatering werd steeds gedaan in proeven, waarin de planten op verschillende tijdstippen na opkomst werden geïnoculeerd. Het ligt voor de hand, dat de leeftijdsfactor eveneens in het spel is bij het bepalen van de verschillen tussen de resultaten van verschillende proeven. Terwille van de overzichtelijkheid zijn in tabel 17 de verschillende tot nu toe beschreven proeven samengevat. Hierin zijn, zo mogelijk, de resultaten opgenomen, die 10 dagen na de inoculatie werden verkregen. In een aantal van de proeven werd op dit tijdstip evenwel niet gerooid; van deze proeven zijn dan de gegevens opgenomen van een latere rooidatum.

Uit het algemene beeld is op te maken, dat naarmate de planten ouder zijn op het tijdstip van de inoculatie, er minder transport van virus plaats vindt. Een juist inzicht wordt echter niet verkregen, o.a. door het feit, dat op verschillende tijdstippen van het jaar werd gewerkt. De ouderdomsresistentie, die, zoals o.a. uit tabel 17 blijkt, zowel in de kas als in het veld optreedt, zal in hoofdstuk 4 uitvoerig worden behandeld.

In de gegevens omtrent het tijdstip van inoculatie en de erop volgende besmetting, die bij alle proeven werden vermeld, is de tendens aanwezig, dat het virustransport in de herfst langzamer is dan in de zomermaanden.

Wat de rasverschillen betreft, valt het op, dat Voran een zeer matig virus- 
TABEL 17. Samenvattend overzicht van de proeven, aangaande het transport van aardappel $\mathrm{X}$-virus in enige aardappelrassen.

Summary of the experiments concerning the translocation of potato virus $X$ in some potato varieties.

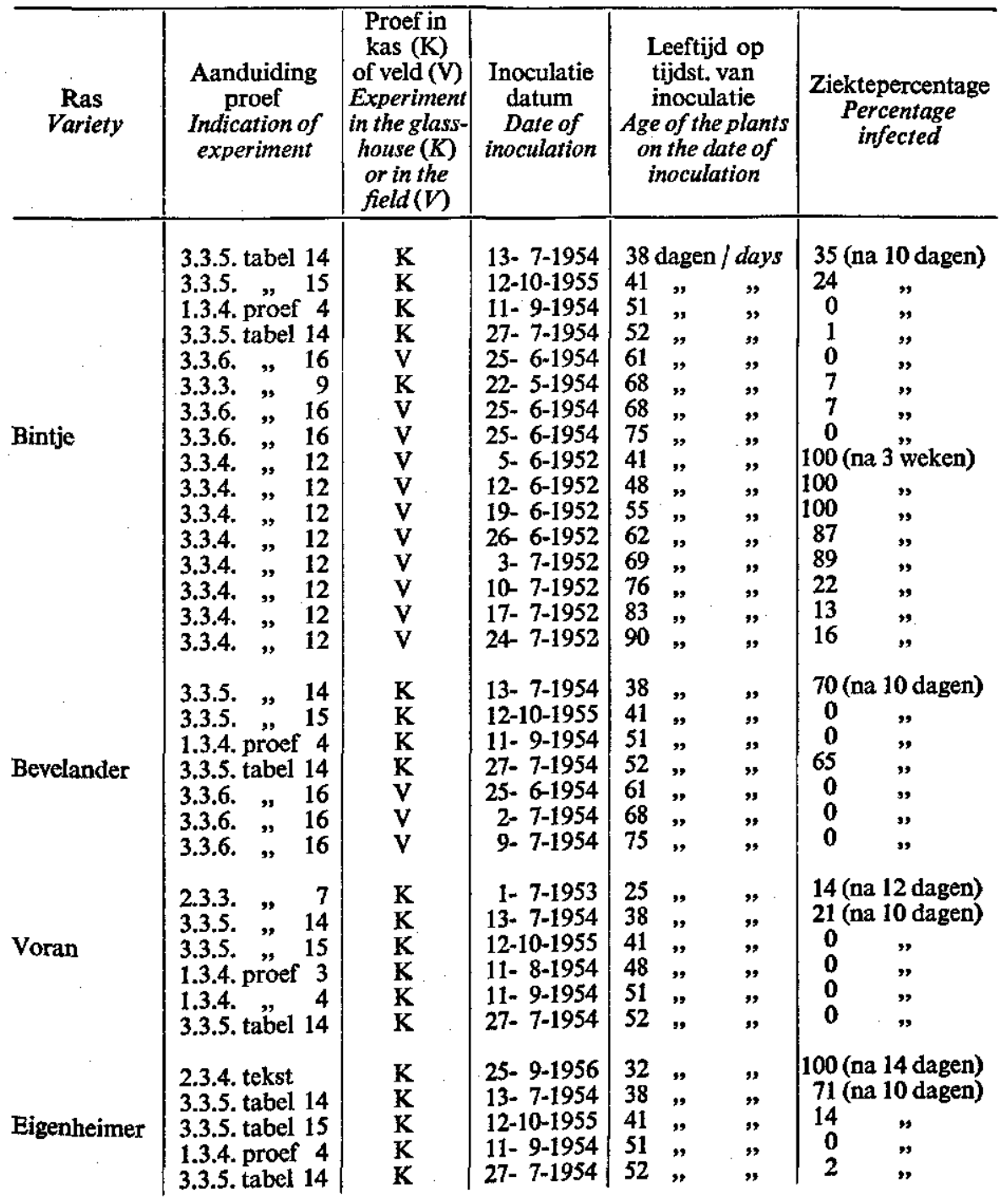

transport te zien geeft in alle ermee uitgevoerde proeven. Het transport bij Eigenheimer daarentegen is vrij snel en intensief. Bintje, waarmede de meeste proeven werden uitgevoerd, neemt wat de snelheid van het transport betreft, een tussenpositie in: een sneller transport dan bij Voran en minder snel dan bij Eigenheimer. Over Bevelander valt weinig met zekerheid te zeggen. Waarschijnlijk vindt onder normale omstandigheden een vrij snel transport plaats, in de herfst werd slechts een matig transport gevonden. 
Uit de gedetailleerde gegevens (zie ook aanhangsel) is te zien, dat de besmetting van het knollenstelsel van een aardappelplant zeer geleidelijk geschiedt. Het virus kan aanvankelijk slechts in enkele knollen en dan nog slechts in enkele ogen worden aangetoond. Naarmate het tijdsverloop tussen de inoculatie en het rooien van de plant groter is, wordt het aantal geinfecteerde knollen en ogen steeds groter. Deze feiten duiden erop, evenals de resultaten van de proeven met de stengelstukken (zie 2.3.2), dat het virustransport in een weinig geconcentreerde stroom plaats vindt. Het komt in het algemeen niet dikwijls voor, dat het gehele knollenstelsel van een plant geheel wordt besmet. Hierbij moeten we evenwel bedenken, dat bij een aantal van de beschreven proeven de periode tussen de inoculatie en het rooien betrekkelijk kort was. Uit proef 3.3.5.2 (zie tabel 15 en aanhangsel) zien we echter, dat er zelfs 43 dagen na de inoculatie nog steeds geheel of gedeeltelijk gezonde knollen kunnen voorkomen.

Opgemerkt kan worden, dat in de meeste gevallen de knollen, die van de proefplanten werden verkregen, gepoot werden na bewaring in een luchtgekoelde poterbewaarplaats gedurende de periode van het rooien tot het tijdstip van poten. Uit de resultaten van de verschillende proeven kan worden afgeleid, dat de verplaatsing van het virus na het rooien, onder de boven geschetste omstandigheden van geen betekenis is geweest. Was dit nl. wel het geval, dan zouden of geheel zieke, of geheel gezonde knollen moeten zijn gevonden. Een speciale proef hierover zal worden besproken in hoofdstuk 5. Tevens zal dan worden ingegaan op de vraag, welke knollen van een plant en welke ogen van een knol worden besmet. 
HOOFDSTUK 4

\section{NADER ONDERZOEK OVER DE OUDERDOMSRESISTENTIE}

\subsection{INLEIDING EN LITERATUUR}

Omtrent de ouderdomsresistentie van de aardappelplant ten aanzien van het $\mathrm{X}$-virus werd door BERCKs uitgebreid onderzoek verricht. Een kort overzicht van de door hem gepubliceerde resultaten moge hier volgen. Proeven (BERCKS, 1949) hadden tot resultaat, dat het X-virus zeer algemeen in het loof van planten kon worden aangetoond, die respectievelijk 19 (veldproeven) en 24 dagen (kasproeven) na het poten waren geïnoculeerd. Waren de planten evenwel 46 dagen na het poten geïnoculeerd, dan kon vrijwel alleen virus in de geïnoculeerde bladeren worden gevonden. Het verschijnsel kwam algemeen voor, al vertoonden niet alle aardappelrassen het in dezelfde mate.

$\mathrm{Bij}$ een nadere uitwerking van bovenvermelde proeven (BERCKS, 1950a) concludeerde de auteur, dat de ouderdomsresistentie niet kan worden verklaard door te veronderstellen, dat de planten geen enkele activiteit meer vertonen. Ook bij de laatste inoculatie zagen de planten er nl. nog zeer vitaal uit en vertoonden nog groei. Over het tijdstip, waarop de ouderdomsresistentie begint op te treden, kon de auteur geen gegevens mededelen. Dit is volgens hem waarschijnlijk mede afhankelijk van de uitwendige omstandigheden.

Van een drietal rassen uit de bovengenoemde proeven werden door BERCKS (1950b) de knollen getoetst op de aanwezigheid van X-virus. Hij vermeldt niet, op welk tijdstip de planten waren gerooid, zodat niet kan worden uitgemaakt na hoeveel tijd het virus uit het loof in de knollen is gekomen. Uit de resultaten van de toetsingen van de knollen blijkt, dat minder knollen worden besmet, naarmate het tijdstip van inoculatie later wordt gekozen. Het bleek, dat ook bij in een jong stadium geïnoculeerde planten niet altijd een $100 \%$ zieke nateelt werd gevonden. Er komt wel een gering percentage virus voor in de nateelt van die planten, waarin (serologisch) geen virus in het loof kon worden aangetoond. BERCKs constateerde ook, dat ten aanzien van de besmetting van de knollen sterke verschillen tussen verschillende rassen bestaan en dat verschillende vormen van het virus een verschillend effect hebben.

Later vermeldt BERCKs (1951) nader onderzoek, waarin de vroegere resultaten volledig konden worden bevestigd met een groter aantal virusstammen. Verder bleek, dat de bemesting invloed heeft op de mate van optreden van de ouderdomsresistentie en wel in deze zin, dat op een grond, waarop de aardappelplant slecht groeit, de ouderdomsresistentie op een vroeger tijdstip begint op te treden dan op een goed bemeste grond. BERCKs wijst er ook hier weer op, dat een stilstand in de groei niet de oorzaak kan zijn van het verschijnsel. Als mogelijke factor bij de ontwikkeling van de ouderdomsresistentie brengt BERCKs de eiwitstofwisseling naar voren. Hij schrijft: „Bekanntlich darf man sich letzteren (de eiwitstofwisseling) als ein dynamisches Geschehen vorstellen bei dem Aufbau bzw. Abbau in den verschiedenen Entwicklungsstadien überwiegt. Der 
Eiweiszspiegel wird nach dieser Auffassung bei einer mehr oder weniger ausgewachsenen Pflanze dadurch gehalten, dasz Auf- und Abbau nur sehr schwach sind und sich gegenseitig Waage halten."

Uit een nader onderzoek met de rassen Flava en Capella concludeerde BERCKs (1952), dat het verschil in bemestingstoestand van de grond, zoals deze in de praktijk doorgaans voorkomt, geen invloed heeft op het tijdstip van optreden van de ouderdomsresistentie. Bij het midden-vroege ras Flava zette de resistentie eerder in dan bij het late ras Capella.

MARCUS (1952) en KöHLER (1955) hebben aangetoond, dat het verschijnsel van de ouderdomsresistentie zich ook ten aanzien van het aardappel Y-virus voordoet.

Zonder op enigerlei wijze nader op de ouderdomsresistentie als zodanig in te gaan, is in de loop der jaren door verschillende auteurs wel vermeld, dat de virusverspreiding in een aardappelgewas sterker is, naarmate de planten jonger zijn op het tijdstip van de inoculatie of een krachtiger groei vertonen door b.v. hogere stikstofbemesting (KöHLER, 1938; DIERCKS, 1953; ARENZ, 1956).

Ook andere waarnemingen wijzen op het bestaan van de ouderdomsresistentie. Zo schrijft b.v. GREGORY (1943),,... it is possible to find large populations of M.persicae or A.rhamni with very little spread from leaf roll or virus $\mathrm{Y}$ infectors to near-by plants. Or again there can be a large spread of leaf roll with low M.persicae and moderate A.rhamni counts." Het is zeer wel mogelijk, dat GREGORY een foutieve conclusie trekt, als hij vervolgt: „Local factors controling aphid movement must also be important. E.g. it was noticed that on several fields when the haulm remained small and compact the percentage of plants affected with leaf roll did not increase after July, whereas in other fields remarkable for the immense growth of haulm (6-7 ft. and weighing 25 tons/ acre) the largest increase of leaf roll in August and early September were recorded. It seems likely that a sprawling and densely interlacing foliage would greatly facilitate the movement of wandering aphides such as the apterae of $M$.persicae from plant to plant." Later zijn echter ook de Engelse onderzoekers (BROADBENT \& GREGORY, 1948; BROADBENT, GREGORY \& TINSLEY, 1952) tot de conclusie gekomen, dat de leeftijd van het gewas de vatbaarheid voor virusziekten sterk kan beïnvloeden en dat daardoor, ondanks de aanwezigheid van veel bladluizen, een geringe infectie met bladrol- en $Y$-virus in een aardappelgewas kan worden geconstateerd.

Tot slot een citaat van een Zwitsers onderzoeker (MÜNSTER, 1954), die schrijft: ,....il est notoire que la receptivité des plantes de pommes de terre aux virus diminue avec l'approche de la maturité. Lorsque viennent les grandes invasions estivales de pucerons vecteurs, le danger d'infection est d'autant moins grand que la végétation est plus avancée."

Uit de aangehaalde literatuur blijkt wel, dat de ouderdomsresistentie bij aardappel niet onbekend was. Systematisch onderzoek erover werd evenwel slechts door BERCKs uitgevoerd, die het bestaan ervan duidelijk heeft aangetoond.

In de volgende paragrafen zullen twee proeven worden beschreven, die werden uitgevoerd met het doel, enkele vraagstukken over de ouderdomsresistentie op te lossen. De twee punten van onderzoek hadden betrekking op: 1. Het stadium van de ontwikkeling van de aardappelplant in verband met het optreden van de ouderdomsresistentie en 2 . De virusreproduktie in het geïnoculeerde blad in verband met de ouderdomsresistentie. 


\subsection{DE OUDERDOMSRESISTENTIE \\ EN HET VERBAND MET HET ONTWIKKELINGSSTADIUM \\ VAN DE AARDAPPELPLANT}

Op 26 juli 1956 werden van het ras Bintje 80 knollen gepoot in grote potten, die in een warenhuis werden geplaatst. Van het begin tot het einde van de proef werd de lengte van elke plant (voorzover deze niet waren gerooid) drie maal per week gemeten, zodat een nauwkeurig beeld van de lengtegroei werd verkregen. Op 3 september namen wij een begin van knolvorming waar en inoculeerden van 20 planten het jongste, volkomen ontwikkelde blad met aardappel X-virus, afkomstig van aardappel. Een, twee en drie weken na deze inoculatie werd telkens een nieuwe groep van 20 planten geïnoculeerd. Dit hield dus in, dat elke geïnoculeerde groep één week ouder was op het tijdstip van de inoculatie dan de voorgaande; $5,10,15$ en 20 dagen na de inoculatie van iedere groep werden telkens vijf planten gerooid, waarna van elke plant alle knollen afzonderlijk werden gewogen. Uit deze wegingen kon het totale gewicht van de geoogste knollen per rooidatum worden bepaald, zodat een beeld van het verloop van de knolvorming werd verkregen. $\mathrm{Na}$ bewaring van de knollen gedurende drie tot vijf maanden werden zij gepoot en de eruit opgroeiende planten getoetst op de aanwezigheid van X-virus met Gomphrena globosa. Evenals dit bij reeds eerder beschreven proeven werd gedaan, werden alle knollen in zoveel mogelijk stukken met oog verdeeld, waarna al deze stukken afzonderlijk werden gepoot.

In fig. 4 zijn de lengtegroei van de planten en de mate, waarin de knollen met de tijd in gewicht toenamen, grafisch uitgezet. We zien hieruit, dat de planten ongeveer 14 dagen na het poten boven de grond kwamen en hierna vrij regelmatig in lengte toenamen tot ze ongeveer 45 dagen na het poten ongeveer $70 \mathrm{~cm}$ waren. De lengtegroei was toen tot stilstand gekomen. Zoals uit het verloop van de lijn, die het gewicht van de knollen op verschillende tijdstippen weergeeft, blijkt, neemt omstreeks 45 dagen na het poten de knolvorming een aanvang, waarna de knollen vrij snel en regelmatig in gewicht toenemen tot het

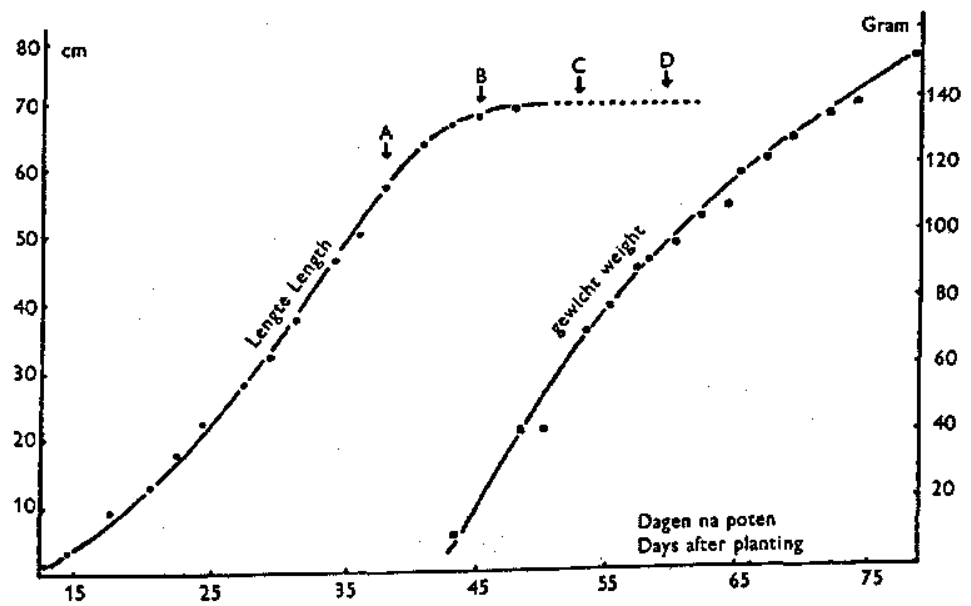

Fro. 4. De gemiddelde lengtegroei van de stengels en de toeneming van het knolgewicht bij het ras Bintje.

The mean growth of the stems and the increase of tuber weight in the variety Bintje. 
einde van de proef (14 oktober, dat is 80 dagen na het poten). Het is duidelijk, dat tijdens de proefperiode geen stilstand in de groei is opgetreden. In fig. 4 zijn met neerwaarts gerichte pijlen (A, B, C en D) de tijdstippen aangegeven, waarop de inoculatie van een groep van 20 planten plaats vond. Hieruit is te zien, dat de eerste inoculatie (A) geschiedde op een tijdstip, waarop de planten nog in lengte toenamen en nog geen knollen hadden gevormd. De tweede groep (B) werd ongeveer op het tijdstip geïnoculeerd, waarop de lengtegroei stopte en de knolgroei begon, terwijl de laatste twee groepen ( $C$ en $D)$ werden geïnoculeerd in de periode, waarin geen lengtegroei, maar alleen nog knolgroei plaats vond. In het aanhangsel (proef 4.2) zijn de volledige resultaten, die bij de toetsing werden verkregen, vermeld. Een samenvatting ervan geeft tabel 18, waarin de volgende gegevens voor iedere groep zijn opgenomen: het aantal planten, waarin enig transport van virus naar de knollen heeft plaats gevonden; het aantal getoetste knollen en het aantal en percentage knollen, waaraan tenminste één ziek oog werd aangetroffen; het aantal getoetste ogen en het aantal en percentage geïnfecteerde ogen. De gegevens van de planten 55, 58 en 69 (zie aanhangsel 4.2) zijn om de volgende reden niet in de gegevens van tabel 18 opgenomen: de planten waren vóór de inoculatie gedeeltelijk afgebroken, waarna zich een nieuwe scheut ontwikkelde. Op een jong blad van deze scheut werden de planten op het volgens schema vastgestelde tijdstip geïnoculeerd. Bij elk van de planten

TABEL 18. De besmetting van de knollen van het aardappelras Bintje na inoculatie van het loof in verschillende groeistadia.

The infection of the tubers of the potato variety Bintje after inoculation of the foliage in different stages of plant growth.

Pootdatum: 26 juli 1956/Planting date: 26 July 1956

\begin{tabular}{|c|c|c|c|c|c|}
\hline \multirow{3}{*}{ ' } & \multirow{3}{*}{$\begin{array}{c}\text { Aantal } \\
\text { dagen na } \\
\text { inoculatie } \\
\text { Number of } \\
\text { days after } \\
\text { inoculation }\end{array}$} & $\mathbf{A}$ & B & C & D \\
\hline & & \multicolumn{4}{|c|}{$\begin{array}{l}\text { Leeftijd op het tijdstip van inoculatie (dagen) } \\
\text { Age at the time of inoculation (days) }\end{array}$} \\
\hline & & 38 & 45 & 52 & 59 \\
\hline $\begin{array}{l}\text { Infectie per } \\
\text { plant } \\
\text { Infection per } \\
\text { plant }\end{array}$ & $\begin{array}{r}5 \\
10 \\
15 \\
20\end{array}$ & $\begin{array}{l}\left.0 / 4^{1}\right) \\
4 / 5 \\
5 / 5 \\
5 / 5\end{array}$ & $\begin{array}{l}0 / 5 \\
0 / 5 \\
2 / 5 \\
2 / 5\end{array}$ & $\begin{array}{l}1 / 5 \\
2 / 5 \\
1 / 4 \\
3 / 4\end{array}$ & $\begin{array}{l}0 / 5 \\
1 / 4 \\
2 / 5 \\
1 / 5\end{array}$ \\
\hline $\begin{array}{l}\text { Infectie per } \\
\text { knol } \\
\text { Infection per } \\
\text { tuber }\end{array}$ & $\begin{array}{r}5 \\
10 \\
15 \\
20\end{array}$ & $\begin{array}{r}\left.0 / 30^{2}\right)=0 \% \\
14 / 52=27 \% \\
17 / 50=34 \% \\
35 / 50=70 \%\end{array}$ & $\begin{array}{l}0 / 42=0 \% \\
0 / 52=0 \% \\
6 / 38=16 \% \\
5 / 34=15 \%\end{array}$ & $\begin{array}{r}1 / 46=2 \% \\
4 / 52=8 \% \\
4 / 33=12 \% \\
21 / 37=57 \%\end{array}$ & $\begin{array}{l}0 / 44=0 \% \\
6 / 37=16 \% \\
3 / 47=6 \% \\
2 / 37=5 \%\end{array}$ \\
\hline $\begin{array}{l}\text { Infectie per } \\
\text { oog } \\
\text { Infection per } \\
\text { eye }\end{array}$ & $\begin{array}{l}5 \\
10 \\
15 \\
20\end{array}$ & $\begin{array}{r}\left.0 / 39^{9}\right)=0 \% \\
33 / 150=22 \% \\
47 / 160=29 \% \\
102 / 164=62 \%\end{array}$ & $\begin{array}{r}0 / 87=0 \% \\
0 / 151=0 \% \\
19 / 174=11 \% \\
16 / 146=11 \%\end{array}$ & $\begin{array}{r}1 / 161=0,6 \% \\
7 / 193=4 \% \\
17 / 139=12 \% \\
56 / 148=38 \%\end{array}$ & $\begin{array}{r}0 / 164=0 \% \\
10 / 132=8 \% \\
4 / 202=2 \% \\
2 / 187=1 \%\end{array}$ \\
\hline
\end{tabular}

I) teller: aantal planten met geinfecteerde knol(len): noemer: aantal proefplanten. numerator: number of plants with infected tuber(s); denominator: number of test plants.

$\left.{ }^{2}\right)$ teller: aantal knollen met een of meer geïnfecteerde ogen; noemer: aantal getoetste knollen. numerator: number of tubers with one or more inefcted eyes; denominator: number of tested tubers.

3) teller: aantal geinfecteerde ogen; noemer: aantal getoetste ogen. numerator: number of infected eyes; denominator: number of tested eyes. 
resulteerde dit in een volledige besmetting van het knollenstelsel. Op de betekenis van deze waarneming zal nog nader worden teruggekomen.

In fig. 5 zijn de gegevens over de besmetting van de ogen grafisch weergegeven.

De resultaten tonen aan, dat vijf dagen na de inoculatie bij geen van de vier groepen virustransport van enige betekenis naar de knollen heeft plaats gevonden; slechts in groep $C$ werd één oog op een totaal van 161 ziek bevonden. De resultaten van de toetsingen van de planten, die 10,15 en 20 dagen na de inoculatie werden gerooid, wijzen uit, dat het transport van het virus in de planten van de eerst geïnoculeerde groep (A) het snelst is geweest. De tweede

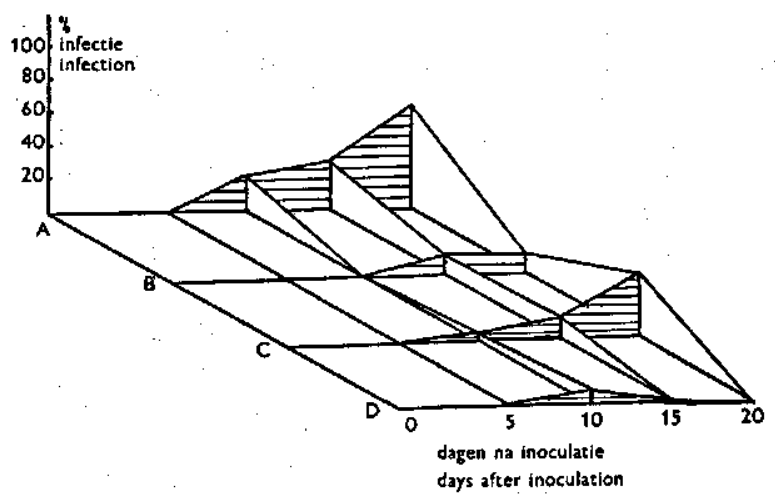

Fig. 5. De percentages van de besmetting van de ogen met $X$-virus bij het ras Bintje 5,10 , 15 en 20 dagen na de inoculatie. Er werden vier groepen van 20 planten, resp. 38, 45,52 en 59 dagen na het poten geïnoculeerd (A, B, C, D).

The percentages of infection of the eyes with virus $X$ in the variety Bintje 5, 10,15 en 20 days after inoculation. Four groups of 20 plants were inoculated $38,45,52$ and 59 days after planting respectively $(A, B, C, D)$.

groep (B) vertoont reeds een aanzienlijk kleiner percentage geïnfecteerde knollen en ogen dan de eerste. Bij de derde groep (C) lijkt een iets sterkere infectie te zijn opgetreden dan bij de tweede groep; bij de laatste groep (D) zien we, dat een zeer gering transport naar de knollen heeft plaats gehad. De hier verkregen resultaten tonen duidelijk aan, dat van het moment af, waarop de knolvorming begint, het transport van virus naar de knollen sterk vermindert. Dit feit kon uit de gegevens, die de in 3.3.4 beschreven proef opleverde, ook reeds worden afgeleid.

Zoals BERCKS $(1950 \mathrm{a}, \mathrm{b})$ uit zijn proeven ook reeds besloot, kan het verminderde virustransport bij oudere planten in geen geval een kwestie zijn van een geringere vitaliteit van de planten. We zien nl. duidelijk uit het verloop van de lijn, die de groei van de knollen aangeeft (fig. 4), dat na de tweede inoculatie (B) de knolvorming nog in het beginstadium verkeert, terwijl op dat moment toch reeds van een belangrijk verminderd virustransport naar de knollen kan worden gesproken.

Met betrekking tot de resultaten van de hier beschreven proef kunnen nog de volgende algemene opmerkingen worden gemaakt. De percentages, die de knolinfectie aangeven, zijn over het algemeen iets hoger dan die van de ooginfectie. De algemene lijn, die de beide cijferreeksen vertonen, is evenwel vrijwel dezelfde. 
Verder zien we hier duidelijk gedemonstreerd, dat ook onder de minst gunstige omstandigheden, dat wil zeggen als de inoculatie in een laat stadium van de ontwikkeling van de plant heeft plaats gevonden, er nog steeds een infectie van een knol tot stand kan komen. De ouderdomsresistentie is dus nooit geheel volledig. Dit feit kon ook reeds uit eerder beschreven proeven worden afgeleid.

\subsection{DE OUDERDOMSRESISTENTIE \\ EN HET VERBAND MET DE VIRUSVERMEERDERING IN HET GEÏNOCULEERDE BLAD}

In de tot dusverre beschreven proeven is het verschijnsel van de ouderdomsresistentie meestal duidelijk opgetreden. Naar aanleiding van de resultaten van de in de vorige paragraaf beschreven proef $k$ on het verschijnsel iets nader worden geanalyseerd. Toch is het niet mogelijk om met de tot nog toe verkregen gegevens uit te maken, aan welke oorzaak het verschijnsel moet worden toegeschreven. In 1957 werd daarom een proef uitgevoerd, waarin werd nagegaan in hoeverre de mate van virusvermeerdering in het geinoculeerde blad beinvloed wordt door de leeftijd van dit blad.

Op 18 april 1957 werden 80 stuks Bintje gepoot in grote potten, die in een warenhuis waren ondergebracht. De planten werden na opkomst op één stengel gehouden en tevens serologisch getoetst op de aanwezigheid van $X$-virus om zeker te zijn, dat met planten werd gewerkt, die vrij van X-virus waren. Op 17 mei, 29 dagen na het poten werden van alle planten drie bladeren gemerkt en wel de volgende:

a. een zeer jong blad in de top van de plant. Dit blad was op 17 mei niet groter dan $8 \mathrm{~cm}$ en juist groot genoeg om te kunnen worden geïnoculeerd.

b. een blad, dat juist volledig ontwikkeld was en op 17 mei in het stadium verkeerde, waarin bij de meeste reeds beschreven proeven het geïnoculeerde
blad zich bevond.

c. een oud blad aan de basis van de stengel.

Te beginnen op 17 mei en vervolgens op 24 en 31 mei en 7 juni werd telkens een groep van 20 planten geïnoculeerd op de drie genoemde bladeren van elke plant. Dit hield dus in, dat de geinoculeerde bladeren op het tijdstip van de inoculatie steeds een week ouder waren dan die, welke de laatste maal waren geïnoculeerd. Uit lengtemetingen van de planten bleek, dat zij op $17 \mathrm{mei} 30 \mathrm{~cm}$ hoog waren, op 24 mei $45-50 \mathrm{~cm}$, op 31 mei en 7 juni beide keren $50-60 \mathrm{~cm}$. We zien hieruit, dat ook in deze proef de planten 40 dagen na het poten niet meer in lengte toenamen. Van de op elk der genoemde data geïnoculeerde planten werden respectievelijk $4,7,11$ en 14 dagen na de inoculatie telkens van vijf planten de geïnoculeerde blaadjes afgeknipt. De vijf blaadjes van respectievelijk top, midden en basis van de planten werden te zamen uitgeperst en het aldus verkregen perssap werd hierna uitgewreven op vijf blaadjes van Gomphrena globosa om een beeld te krijgen van de concentratie van het virus in de geïnoculeerde aardappelbladeren. De Gomphrena-bladeren werden aan de plant vijf verschillende planten. In volgroeide, niet te oude blaadjes van telkens weergegeven; de cijfers geven de to 19 zijn de resultaten van deze toetsingen cijfers grafisch weergegeven. 
TABEL 19. De concentratie van X-virus in aardappelbladeren met betrekking tot de plaats en het groeistadium van de bladeren ten tijde van de inoculatie. De concentratie is uitgedrukt in het aantal vlekken op vijf bladeren van Gomphrena globosa.

Concentration of virus $X$ in potato leaves in relation to the position at the stem and the stage of growth of the leaves at the moment of inoculation. The concentration is expressed in the number of lesions on five leaves of Gomphrena globosa. Pootdatum 18 april 1957/Date of planting: 18 April 1957

\begin{tabular}{|c|c|c|c|c|c|}
\hline \multirow{3}{*}{$\begin{array}{l}\text { Plaats van het } \\
\text { geïnoc. blad } \\
\text { Position of } \\
\text { inoc. leaf }\end{array}$} & \multirow{3}{*}{$\begin{array}{l}\text { Inoculatie } \\
\text { datum } \\
\text { Date of } \\
\text { inoculation }\end{array}$} & \multicolumn{4}{|c|}{$\begin{array}{l}\text { Aantal dagen tussen inoculatie en toetsing op G.globosa } \\
\text { Number of days between inoc. and testing on G.globosa }\end{array}$} \\
\hline & & 4 & 7 & 11 & 14 \\
\hline & & \multicolumn{4}{|c|}{ Aantal vlekken / Number of lesions } \\
\hline Top / Top & $\begin{array}{r}17 \text { mei } \\
24 \mathrm{mei} \\
31 \mathrm{mei} \\
7 \text { juni }\end{array}$ & $\begin{array}{l}12 \\
52 \\
60 \\
20\end{array}$ & $\begin{array}{r}155 \\
287 \\
324 \\
36\end{array}$ & $\begin{array}{r}1047 \\
409 \\
878 \\
\quad 3\end{array}$ & $\begin{array}{r}1296 \\
742 \\
571 \\
3\end{array}$ \\
\hline Midden / Middle & $\begin{array}{l}17 \mathrm{mei} \\
24 \mathrm{mei} \\
31 \mathrm{mei} \\
7 \text { juni }\end{array}$ & $\begin{array}{r}103 \\
28 \\
125 \\
51\end{array}$ & $\begin{array}{l}577 \\
376 \\
654 \\
100\end{array}$ & $\begin{array}{r}1460 \\
724 \\
1160 \\
6\end{array}$ & $\begin{array}{r}2740 \\
768 \\
762 \\
6\end{array}$ \\
\hline Basis / Base & $\begin{array}{r}17 \text { mei } \\
24 \text { mei } \\
31 \text { mei } \\
7 \text { juni }\end{array}$ & $\begin{array}{r}99 \\
98 \\
180 \\
4\end{array}$ & $\begin{array}{r}653 \\
480 \\
1118 \\
143\end{array}$ & $\begin{array}{r}1397 \\
841 \\
1025 \\
8\end{array}$ & $\begin{array}{r}2296 \\
1450 \\
592 \\
48\end{array}$ \\
\hline
\end{tabular}

van het virus niet tot in details betrouwbaar zijn, mag de algemene lijn, die uit de cijfers blijkt, wel als betrouwbaar worden beschouwd. PAUL (1955) kent aan de toets, op de beschreven wijze uitgevoerd, een vrij grote mate van betrouwbaarheid toe.

Zoals uit tabel 19 en fig. 6 blijkt, neemt in het algemeen de concentratie van het virus in het geïnoculeerde blad minder snel toe, naarmate de bladeren ouder zijn op het tijdstip van de inoculatie. $\mathrm{Er}$ is een korte periode, warin weinig verschil kon worden aangetoond (na de inoculaties op 24 en $31 \mathrm{mei}$ ). Bij het beschouwen van het verloop van de concentratie in elk der groepen, zien we, dat in het topblad, vooral aanvankelijk, een aanzienlijk minder snelle virusreproduktie heeft plaats gevonden. De overige verschillen tussen de groepen zijn waarschijnlijk niet betrouwbaar.

Op het tijdstip van het afknippen van de drie geïnoculeerde bladeren werden eveneens de knollen van de planten gerooid om naderhand getoetst te kunnen worden op de aanwezigheid van $\mathrm{X}$-virus. De resultaten van de toetsing van de knollen zijn in detail weergegeven in het aanhangsel, proef 4.3 , terwijl in tabel 20 een samenvatting van de resultaten is vermeld. De resultaten in deze tabel zijn op dezelfde wijze weergegeven als die in tabel 18. De percentages over de besmetting van de ogen zijn in fig. 7 grafisch weergegeven.

We zien over het geheel genomen een iets sterkere besmetting dan in proef 4.2 het geval was. Hiervoor zijn twee oorzaken aan te wijzen, nl. de planten werden in deze proef in een jonger stadium geïnoculeerd (hier $29 \mathrm{~d}$. oud, in de vorige proef $38 \mathrm{~d}$. oud op het tijdstip van de eerste inoculatie), een verschil nl. van ruim een week, hetgeen, zoals reeds eerder werd aangetoond, van groot belang kan zijn. Houden we rekening met deze factor en vergelijken we curve $B$ 

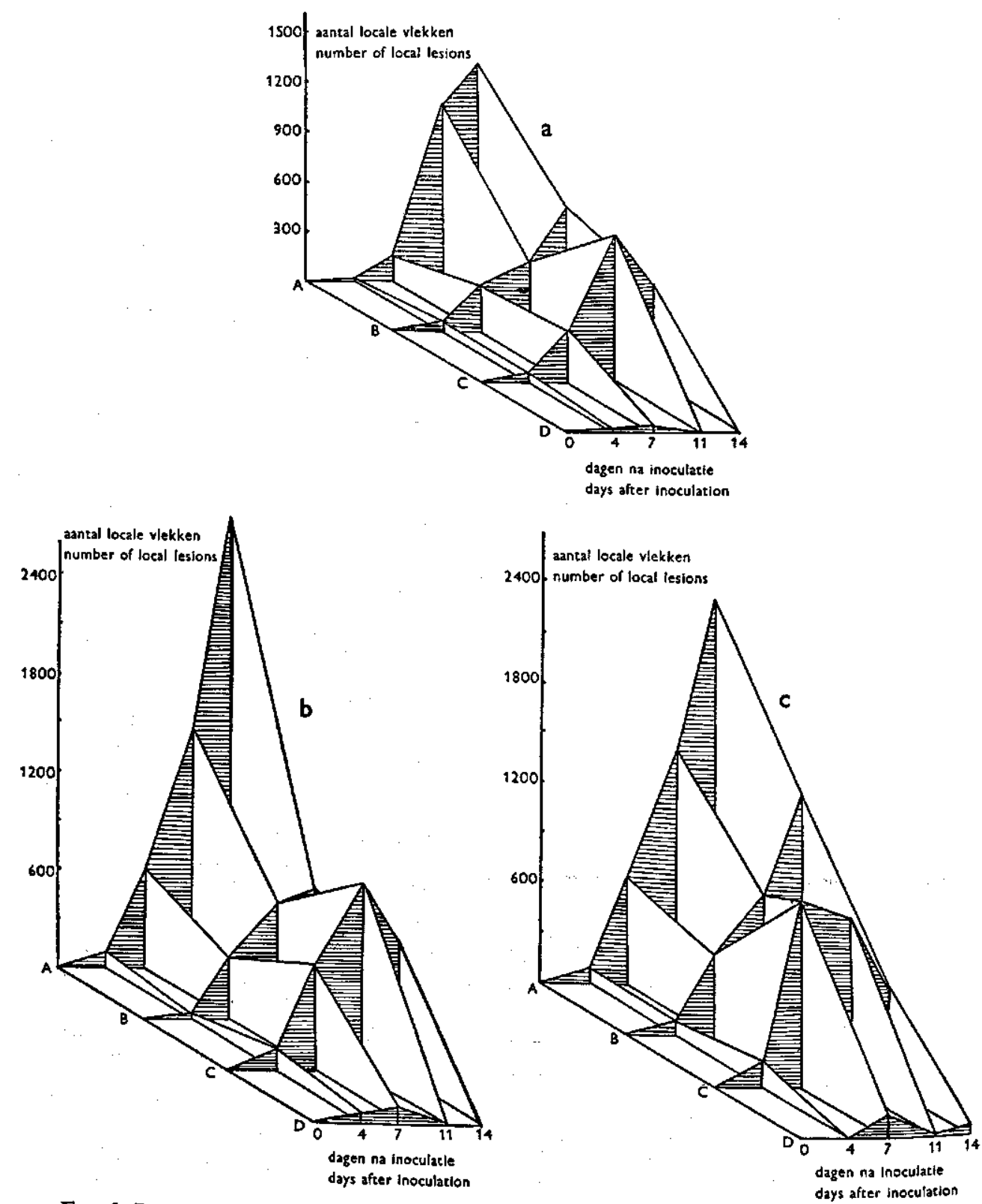

Fio. 6. De concentratie van het $\mathrm{X}$-virus in de bladeren van aardappelen (Bintje) in verband met de leeftijd van de planten, uitgedrukt in het aantal vlekken, dat werd verkregen op vijf Gomphrena globosa-bladeren. A, B, C en D: de tijdstippen van inoculatie, The concentration of wirus $X$ verschil. a: topblad; b: middenblad; $\mathrm{c}$ : basisblad. of the plants, expressed in the number of led leaves of potatoes in relation to the age globosa. $A, B, C$ and $D:$ dates of inor of lesions obtained on five leaves of Gomphrena leaf; $c$ : basal leaf. 
TABEL 20. De besmetting van de knollen van het aardappelras Bintje na inoculatie van drie bladeren in verschillende groeistadia.

The infection of the tubers of the potato variety Bintje after inoculation of three leaves in different stages of growth.

Pootdatum: 18 april 1957 / Date of planting: 18 April 1957

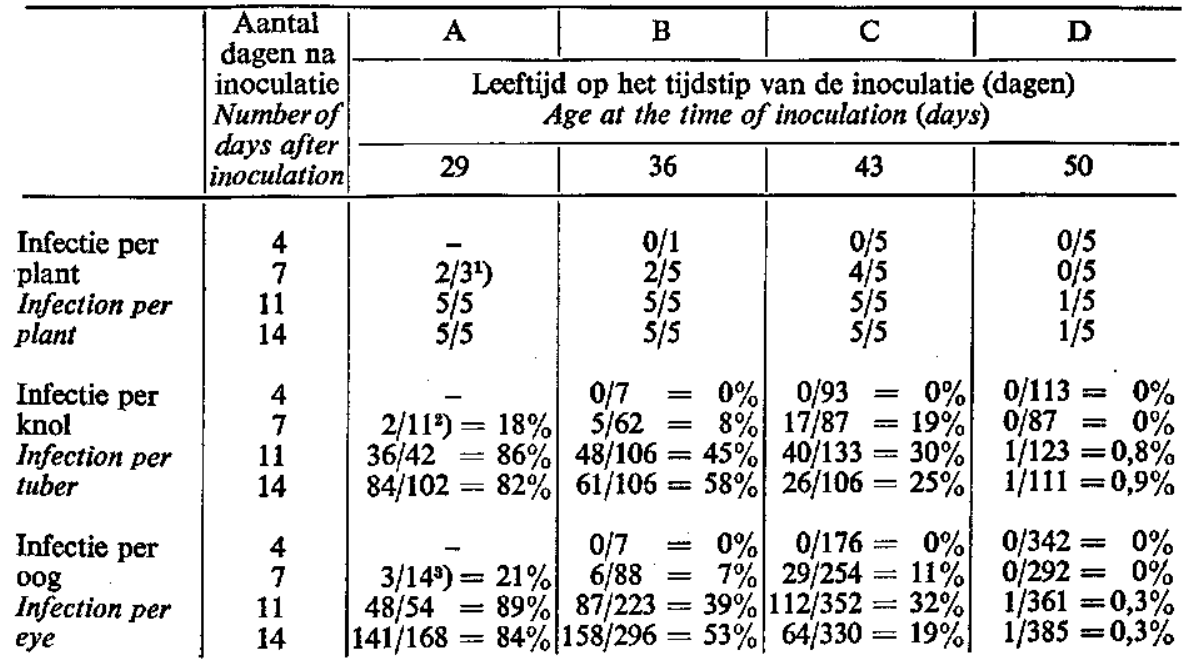

1) teller: aantal planten met geĭnfecteerde knollen; noemer: aantal proefplanten.

numerator: number of plants with infected tuber(s); denominator: number of test plants.

$\left.{ }^{2}\right)$ teller: aantal knollen met één of meer geïnfecteerde ogen; noemer: aantal getoetste knollen. numerator: number of tubers with infected eye(s); denominator: number of tested tubers.

s) teller: aantal geinfecteerde ogen; noemer: aantal getoetste ogen.

numerator: number of infected eyes; denominator: number of tested eyes.

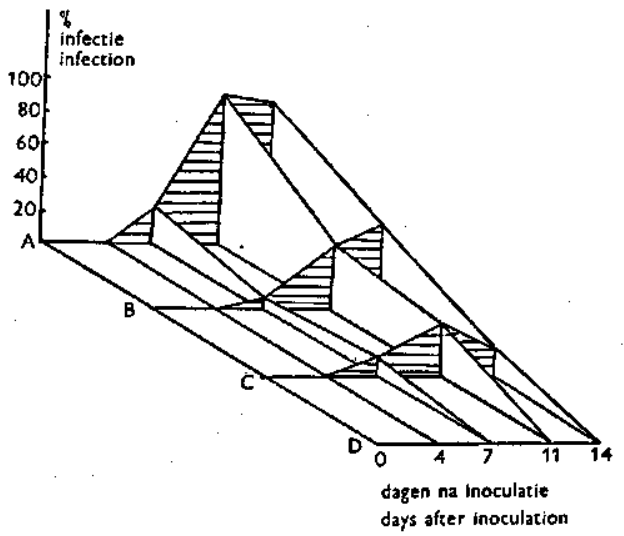

Fic. 7. De percentages van de besmetting van de ogen met $X$-virus bij het ras Bintje 4, 7, 11 en 14 dagen na de inoculatie. Er werden vier groepen van 20 planten resp. 29, 36, 43 and 50 dagen na het poten geïnoculeerd $(\mathrm{A}, \mathrm{B}, \mathrm{C}, \mathrm{D})$.

The percentages of infection of the eyes with virus $X$ in the variety Bintje 4,7,11 en 14 days after inoculation. Four groups of 20 plants were inoculated $29,36,43$ and 50 days after planting respectively $(A, B, C, D)$. 
(fig. 7 ) met curve A in fig. 5 (deze beide series zijn vergelijkbaar wat betreft het tijdstip van inoculatie), dan blijkt tussen beide series een zekere overeenkomst te bestaan, al is de besmetting in de laatste proef iets sterker. Een tweede factor, die tot een verhoging van de knolinfectie aanleiding kan zijn geweest, is het feit, dat hier drie bladeren werden geïnoculeerd tegenover in proef 4.2 slechts één. Een proefje hierover gaf het volgende resultaat te zien. $\mathrm{Na}$ inoculatie op één blad gaven groepen van vijf planten na 10 en 15 dagen respectievelijk 1 en $23 \%$ zieke ogen; na inoculatie van drie bladeren waren deze percentages op dezelfde tijdstippen 30 en 42 . Hieruit volgt, dat na inoculatie van drie bladeren inderdaaad een sterkere besmetting optreedt.

Vergelijken we nu de toeneming van de virusconcentratie in de geïnoculeerde bladeren met de mate van infectie van de knollen, dan blijkt hiertussen enige samenhang te bestaan. We zien nl., dat vier dagen na de inoculatie een nog betrekkelijk lage concentratie van het virus in de geïnoculeerde bladeren in alle series aanwezig is. De besmetting van de knollen betekent op dat moment nog geheel niets. Zeven dagen na de inoculatie zien we, dat de concentratie van het virus in de geïnoculeerde bladeren reeds van enige betekenis is, speciaal in het middelste en laagst geplaatste blad. We zien, dat het transport van het virus naar de knollen dan ook is begonnen en resulteert in een, zij het nog matige besmetting daarvan. De concentratie van het virus in het geïnoculeerde blad vertoont dezelfde lijn als de besmetting van de knollen, nl. een grotere concentratie en een sterkere besmetting, naarmate in een jonger stadium werd geinoculeerd. Tussen de series $B$ en $C$ is weinig verschil aan te wijzen. Het algemene beeld 11 en 14 dagen na de inoculatie is vrijwel gelijk met dat van zeven dagen na de inoculatie. Natuurlijk liggen de cijfers op een iets hoger niveau omdat de virusvermeerdering en het transport ervan verder zijn voortgeschreden.

Op één enkel punt moet nog nader worden ingegaan. Het is nl. opvallend, dat we na de inoculatie op 31 mei (curve $C$, fig. 6 ) de concentratie van het virus zien afnemen tussen de elfde en de veertiende dag na de inoculatie en wel in alle drie groepen van bladeren. Het werkwaardige feit doet zich nu voor, dat ook de besmetting van de knollen na de inoculatie op 31 mei (curve $C$, fig. 7) een vermindering vertoont tijdens dezelfde periode, waarin ook een concentratievermindering van het virus in het geïnoculeerde blad werd geconstateerd. We moeten hierbij wel bedenken, dat we met verschillende groepen van planten te maken hebben gehad op de verschillende rooidata. Toch lijkt het gerechtvaardigd in dit geval de vermindering van de knolbesmetting nader te beschouwen met het oog op de opvallende concentratievermindering van het virus in de geïnoculeerde bladeren.

Het is wel bekend, dat de concentratie van het X-virus bij het ouder worden van een zieke aardappelplant (BARTELs, 1955) en van een zieke tabaksplant (BERCKS, 1954, 1956) geringer wordt naarmate deze planten ouder worden. Het is echter niet waarschijnlijk, dat het hier naar voren gekomen feit op één lijn kan worden gesteld met dat, wat de hier aangehaalde auteurs beschreven. Zo spreekt BARTELS van een vermindering van de concentratie bij vijf weken oude aardappelplanten, gerekend over de gehele secundair zieke plant en dus niet over de concentratie in het geìnoculeerde blad. We moeten dus een andere oorzaak van het in de proef gevonden feit kunnen aanwijzen. Het bleek nu, dat van 12 tot en met 18 juni extreem hoge temperaturen zijn voorgekomen, die 
gedurende een groot gedeelte van de dag hoger dan $30^{\circ} \mathrm{C}$ waren. Uit desbetreffende gegevens ${ }^{1}$ ) is gebleken, dat in de er vóór liggende periode de temperatuur slechts op een enkele dag voor een korte tijd boven $30^{\circ} \mathrm{C}$ is geweest. Het ligt voor de hand om in de extreem hoge temperatuur de oorzaak te zoeken voor het feit, dat in de aangeduide periode een vermindering van de virusconcentratie werd gevonden. Het is niet waarschijnlijk, dat dit te wijten is aan een verandering in de vatbaarheid van G.globosa, aangezien deze toetsplant steeds in een gekoelde kas bij vrijwel constante temperatuur werd gekweekt. Mogelijk is het een rechtstreeks effect van de verhoogde temperatuur op het virus, zoals Kassanis (1954) beschreef. Anderzijds heeft NienHaus (1957) gewezen op het feit, dat bij hoge (en lage) temperatuur in aardappelplanten een stof ontstaat, die het aanslaan van Y-virus. in de toetsplant belemmert. Zou deze waarneming ook voor X-virus met G.globosa als toetsplant gelden, dan zou de door ons verrichte bepaling van de $\mathrm{X}$-virusconcentratie hierdoor ongunstig zijn beïnvloed.

De daling van de concentratie vond plaats in de periode van 11 tot 14 juni, waarin, zoals gezegd, de hete periode is begonnen. Dezelfde invloed heeft zich waarschijnlijk doen gelden op de resultaten, die werden verkregen in de vierde serie (curve D, fig. 6). Het verschijnsel van de ouderdomsresistentie kan hierdoor zijn geflatteerd, hoewel dit niet noodzakelijk het geval behoeft te zijn geweest. Afgezien hiervan is het evenwel duidelijk dat de concentratie van het virus in het geïnoculeerde blad ten nauwste samenhangt met de mate, waarin besmetting van de knollen optreedt.

Tenslotte rijst nog de vraag of het feit, dat het ziektepercentage van de ogen van de 11 e tot de 14 e dag afneemt (curve $C$, fig. 7) wijst op een verdwijning van het reeds in de knollen aanwezige virus. Het kan zijn, dat deze vermindering alleen berust op een toevallige factor en dus als een waarnemingsfout kan worden beschouwd. Anderzijds is het evenwel opmerkelijk, dat de vermindering gedurende dezelfde periode optrad, als waarin eveneens een vermindering van de virusconcentratie in de geïnoculeerde bladeren werd gevonden. (Vergelijk fig. 6 en 7). Daarom willen wij nagaan, of een eventuele vermindering van de besmetting van de ogen voor mogelijk kan worden gehouden. Hoewel het in principe mogelijk is gebleken om bepaalde virussen, zoals b.v. het bladrolvirus (KASSANIS, 1950) door hoge temperatuur in de knollen te inactiveren, is het tot nog toe niet gelukt X-viruszieke knollen op deze wijze te genezen. Toch is het niet ondenkbaar, dat in knollen, waar een geringe concentratie van het virus aanwezig is, hiervan een gedeelte wordt geinactiveerd bij hoge temperatuur. Er zou echter nog een tweede verklaring voor het hier gevonden verschijnsel zijn aan te voeren en wel de volgende. Nadat in de bladeren ten gevolge van de hoge temperatuur de virusconcentratie vrij sterk is afgenomen, heeft het transport ervan naar de knollen opgehouden. Zoals uit de gegevens over de knolgroei is gebleken, nam het gewicht van de knollen tijdens de hete periode nog toe. Uit deze beide factoren zou dan een relatieve vermindering van het virus in de knollen kunnen worden verklaard.

1) Ir. A. M. VAN DooRN wordt hierbij hartelijk dank gezegd voor het beschikbaar stellen van de gegevens. 


\subsection{ALGEMENE BESPREKING VAN DE RESULTATEN}

Zoals uit vrijwel alle tot dusverre beschreven proeven is gebleken, worden minder knollen met X-virus geïnfecteerd, naarmate een plant op een later tijdstip van haar ontwikkeling in het loof wordt besmet. Dit verschijnsel wordt aangeduid met de naam ouderdomsresistentie. De verschillende proeven wijzen duidelijk uit, dat dit begrip slechts relatieve betekenis heeft, d.w.z. zelfs bij planten, die in een vrij laat stadium worden geïnoculeerd, kan de inoculatie nog steeds aanleiding geven tot een geringe besmetting van de knollen.

Uit de in dit hoofdstuk beschreven proeven, waarbij de ontwikkeling van het gewas nauwkeurig werd gevolgd, kon worden afgeleid, dat de ouderdomsresistentie optreedt van het moment af, waarop de knolvorming een aanvang neemt. Onder de gegeven omstandigheden was dit steeds ongeveer het tijdstip, waarop de lengtegroei van de stengel een einde nam. $\mathrm{Na}$ het begin van de knolvorming volgt een periode, waarin de mate van knolbesmetting intermediair is. Deze periode duurde in de door ons uitgevoerde proeven hoogstens twee weken. Hierna treedt een periode in, waarin vrijwel geen knolbesmetting meer plaats vindt.

Wat is nu de oorzaak van het verschijnsel van de ouderdomsresistentie? De naam zou kunnen suggereren, dat het hier zuiver een kwestie van ouderdom betreft, waarbij de plant een seniele fase intreedt en dat van dat moment af geen virusreproduktie en -transport plaats kunnen vinden. Uit een in dit hoofdstuk beschreven proef evenwel is duidelijk gebleken, dat de virusreproduktie bij planten, die de ouderdomsresistentie vertonen, hoewel niet optimaal, toch nog steeds zeer aanzienlijk is. Zo kon b.v. in serie B (tabel 19 en fig. 6) weliswaar veel minder virus in het geïnoculeerde blad worden aangetoond dan in serie A op de overeenkomstige tijdstippen, maar de aantallen vlekken (b.v. meer dan 700 per vijf Gomphrena-bladeren) vormden toch geen hoeveelheden, die a priori een verminderde besmetting van de knollen zouden doen veronderstellen. Toch blijkt de mate van knolbesmetting aanzienlijk minder te zijn (tabel 20 en fig. 7) en uit de gegevens van de gehele proef blijkt een zekere samenhang tussen de virusconcentratie in het geinnoculeerde blad en de mate van knolbesmetting.

Om tot een redelijke verklaring van dit verschijnsel te kunnen komen, moeten we ons afvragen, of een optimale virusvermeerdering in het geïnoculeerde blad wel leidt tot een zo sterke besmetting van de knollen als men geneigd is aan te nemen. Het antwoord op deze vraag is niet moeilijk te geven met behulp van de tot nog toe verkregen gegevens. Het blijkt nl. steeds, dat er, ook onder de meest ideale omstandigheden, d.w.z. na inoculatie van een plant, die in een jong stadium verkeert, nog lang na de inoculatie van zulk een plant knollen geoogst kunnen worden, die geheel of gedeeltelijk vrij van virus zijn gebleven. Het is dus blijkbaar zo, dat ook indien veel virus in het geïnoculeerde blad (en eventueel op andere plaatsen) wordt geproduceerd, er toch maar zeer weinig virusdeeltjes in de knollen terecht komen, of dat, zo dit wel het geval zou zijn, deze daar in het geheel geen aanleiding zouden geven tot een infectie van de uit de knol opgroeiende plant. Deze laatste veronderstelling wordt evenwel door geen enkele waarneming gesteund. In dit verband kan nog worden opgemerkt, dat virus vrij moeilijk op directe wijze in aardappelknollen kan worden aangetoond, hetgeen ook al zou kunnen wijzen op een geringe virusconcentratie in de knollen. Moeten we dus als het meest waarschijnlijke aannemen, dat er werkelijk een zeer minieme hoeveelheid van het totaal gereproduceerde virus in de knollen 
terecht komt, dan volgt hieruit, dat een vermindering van de virusreproduktie in het geinnoculeerde blad direct aanleiding geeft tot een merkbare vermindering van de knolbesmetting, die zoals uit de laatste proef is gebleken, inderdaad relatief gelijke tred daarmee houdt.

We stuiten nu dus op het volgende probleem, waarvan de oplossing een duidelijk inzicht kan geven in de aard van de ouderdomsresistentie: wat is de oorzaak van het feit, dat een sterke virusvermeerdering in het geïnoculeerde blad niet leidt tot een volledige en snelle besmetting van de knollen? Het virus wordt tijdens het transport naar de knollen op de een of andere wijze verhinderd tot in de knollen door te dringen. Dit zou op verschillende wijzen kunnen worden verklaard, zoals door inactivering, afbraak of doordat virusmoleculen te groot zouden zijn om onbelemmerd te kunnen worden vervoerd. Er zijn nu twee mogelijkheden met betrekking tot de plaats waar dit zou kunnen geschieden en wel: 1. bij de overgang van de cellen, waar het virus wordt gevormd, naar de zeefvaten. Men zou zich voor kunnen stellen, dat het virus hierdoor het geïnoculeerde blad niet gemakkelijk kan verlaten en dat aldus een zeer zwakke concentratie aan virus door de stengel wordt vervoerd en 2 . in de stengel (het virus wordt in dit geval uit het geïnoculeerde blad gevoerd, maar wordt tijdens het transport door de stengel op een of andere wijze geinactiveerd).

KöHLER (1956) heeft uit proeven met X- en Y-virus op tabak gegevens verkregen, waaruit blijkt, dat in oude tabaksplanten het $X$-virus nog slechts moeilijk uit een blad aan de basis van de plant de top kan bereiken. Het Y-virus daarentegen ondervindt geen merkbare belemmering. Het lijkt aannemelijk, dat het door KöHLER gevonden verschijnsel eveneens een vorm van ouderdomsresistentie is. Hij komt op grond van zijn resultaten tot de conclusie, dat het X-virus op een of andere wijze in de stengel tot inactivering is gebracht. Bij het verklaren van een aantal verschijnselen neemt KöHLER nog aan, dat de inactiveringscapaciteit van de stengel niet onbeperkt is en er dus in zekere gevallen voor het virus een mogelijkheid is om toch een eindweegs door te dringen. Hij beschrijft een proefje, waaruit volgt, dat het virus wel uit de bladeren in de bladsteel terecht komt. Hieruit zou blijken, dat het geringe transport niet kan worden toegeschreven aan het feit, dat het virus niet uit het geïnoculeerde blad treedt. Toch maakt KöHLER wel de opmerking, dat zijn proeven aantonen, dat het virus vrij laat uit het geïnoculeerde blad is gevoerd, welk feit dus zou pleiten voor een verhindering van het transport van blad naar stengel. De door KöHLER naar voren gebrachte hypothese komt dus overeen met de tweede verklaring, die hierboven werd gegeven om het geringe virustransport te verklaren. Met deze hypothese kunnen vrijwel alle verschijnselen, die met het transport van virus in de aardappelplant te maken hebben, worden verklaard. Doch, zoals uit enkele voorbeelden zal blijken, is ook de eerste hypothese aantrekkelijk.

Het verschijnsel, dat bepaalde stengelstukken, waarlangs het virustransport plaats vindt, virusvrij blijven, zou volgens de tweede hypothese niet behoeven te wijzen op een geringe concentratie van de virusstroom in de stengel. Het grootste gedeelte van het virus zou nl. tijdens het transport door de stengel worden geinactiveerd. Daar het verschijnsel ook bij jonge planten meermalen werd gevonden en KöHLER zijn hypothese heeft gegeven naar aanleiding van proeven met oudere planten, ligt het meer voor de hand om aan te nemen, dat er maar zeer weinig virus uit het geïnoculeerde blad is getreden en dat hierdoor de concentratie van het virus in de stengel steeds vrij laag is. 
Hetzelfde geldt voor de verklaring van het feit, dat bij primaire infectie de knollen van een aardappelplant niet alle en elke knol niet geheel met het Xvirus worden besmet. Dit zien we soms ook bij planten, die in een jong stadium worden geïnoculeerd. Zou inactivering tijdens het transport in de stengel plaats vinden, dan zou de inactivering in jonge planten minstens van even grote betekenis zijn als in de oude planten, daar de virusreproduktie in bladeren van jonge planten, zoals werd aangetoond, veel groter is dan in bladeren van oude planten.

Het feit, dat in proef 4.2 bij een drietal planten, die werden geïnoculeerd op een nieuwe scheut aan de oude stengel een volledige besmetting van de knollen tot stand gekomen is, wijst er in ieder geval op, dat de mogelijkheid tot transport in oude stengels wel aanwezig is. De grote virusreproduktie in de bladeren van de jonge scheut heeft in deze gevallen aanleiding gegeven tot een totale besmetting van de knollen. Indien we de hypothese van KöHLER volgen, dan zou hier de inactivering van alle virus in de stengel niet mogelijk zijn. De eerste hypothese verschaft echter een minder gecompliceerde verklaring. Het blad aan de jonge scheut produceert $\mathrm{nl}$. een zodanige hoeveelheid virus, dat er betrekkelijk veel getransporteerd kan worden.

De proeven, die in hoofdstuk 1 werden beschreven omtrent het bepalen van het tijdstip, waarop het virus uit het geïnoculeerde blad wordt vervoerd bij aardappel, tabak en Physalis floridana zouden, indien de tweede hypothese juist was, weinig waarde hebben en dus tot foutieve conclusies hebben geleid. Zo werd b.v. gevonden, dat uit de bladeren van niet al te jonge aardappelplanten het virus niet of eventueel pas na lange tijd, uit het geïnoculeerde blad wordt gevoerd. Dit zou dan kunnen worden toegeschreven aan het feit, dat het virus, dat wel in de stengel is terecht gekomen, daar vrij snel tot inactivering is gebracht. Op deze wijze zou het binnentreden van het virus in de stengel niet tot een werkelijke infectie leiden.

We willen nog enkele punten naar voren brengen, die minder gemakkelijk met de tweede hypothese in overeenstemming zijn te brengen of in ieder geval een minder gecompliceerde verklaring vragen indien we de eerste toepassen. Volgens KöHLER onderging het Y-virus in de door hem uitgevoerde proeven geen, of althans in veel mindere mate, inactivering in de stengel. De inactivering in de stengel zou dus zeer specifiek moeten zijn. Dit nu is niet onmogelijk, maar toch minder goed voor te stellen. We zouden nl. een specifieke inactivering (afbraak, blokkering) moeten veronderstellen waarvan het bestaan, in het algemeen gesproken, niet bekend is.

Uit enkele door ons uitgevoerde proeven is gebleken, dat het virus ook na inoculatie op oudere planten toch nog in een enkel geval snel in de knollen kan doordringen. Dit zou volgens de tweede hypothese betekenen, dat, hoewel zulke planten een sterke inactivering van getransporteerd virus vertonen, dit toch hieraan weet te ontsnappen. Gezien de resultaten met jonge planten, waaruit blijkt, dat de inactiverende invloed van de stengel aanzienlijk zou moeten zijn, lijkt dit minder aannemelijk. Daarentegen vindt er, volgens de eerste theorie, bij een geringe virussynthese ook een zeer gering transport plaats, waarbij we het als een kanskwestie kunnen zien of er in sporadische gevallen ook een enkele maal snel virus in de knollen terecht komt.

Zoals wij zojuist hebben gezien, zou volgens de tweede theorie niet kunnen worden uitgemaakt, op welk moment het virus het geïnoculeerde blad verlaat. 
Maar toch willen wij de in hoofdstuk 1 gegeven resultaten en de daarbij gegeven conclusies volledig handhaven. Er zijn nl. in verschillende proeven bepalingen uitgevoerd om de virusvermeerdering in het geïnoculeerde blad te toetsen. Hoewel deze bepalingen niet alle kwantitatieve gegevens opleverden, kan wel uit het totaal van de resultaten worden geconcludeerd, dat de virusvermeerdering in de geïnoculeerde bladeren, waaruit het virus pas laat of in het geheel niet werd afgevoerd, steeds zeer klein was. In enkele proeven werd bij aardappel ook de top boven het geïnoculeerde blad afgesneden en hoewel de afstand, die het virus in deze gevallen moest afleggen om in de nieuwe top door

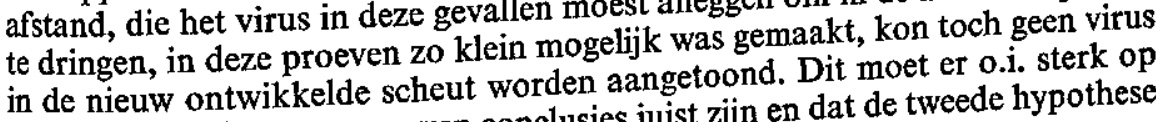
wijzen, dat de door ons gegeven conclusies juist zijn en dat de tweede hypothese voor deze gevallen niet op gaat.

Naar aanleiding van deze beschouwingen kan worden geconcludeerd, dat de in de voorgaande hoofdstukken beschreven proefresultaten op ongedwongen wijze kunnen worden verklaard met de hypothese, die uitgaat van de gedachte, dat het virus bij de overgang van de cellen, waar het werd gevormd, naar de zeefvaten moeilijkheden ontmoet. Dit in tegenstelling tot de tweede hypothese, die op zichzelf niet voldoende is om een aantal hier genoemde feiten te verklaren.

Wij hebben een verklaring trachten te geven voor het feit, dat een verminderde virusreproduktie in het geïnoculeerde blad leidt tot een verminderde besmetting van de knollen. Hiermede is evenwel de werkelijke oorzaak van de smetting van de knollen. Hiermede is even belang hiervoor is het antwoord op
ouderdomsresistentie niet aangegeven. Van
de vraag, waardoor de verminderde virusreproduktie in het geinoculeerde blad wordt veroorzaakt.

BERCKS (1951) heeft er reeds op gewezen, dat een verandering in de verhouding van opbouw en afbraak van eiwitten mogelijk met de door GRÜMMER (1954) gevonden feiten is het inderdaad zeer aannemelijk, dat er een verband bestaat tussen de eiwitstofwisseling en de ouderdomsresistentie. GRÜMMER heeft nl. met behulp van stikstofbepalingen aangetoond, dat in de bladeren van aardappelplanten op het tijdstip, waarop de knolvorming een aanvang neemt, de eiwitafbraak de opbouw ervan gaat overheersen. ligt het voor de hand om als een vorm van eiwitsynthese kan worden gezerherst door de afbraak, ook aan te nemen, dat, als de virussynthese minder sterk zal zijn. En, zoals gebleken is, heeft een vergevolge. Aldus kan de ouderdomsresistentie worden gezien in samenhang met de eiwitstofwisseling van de bladeren.

$\mathrm{Er}$ is één punt, dat in verband met de ouderdomsresistentie nog kan worden genoemd. Dit is $\mathrm{nl}$. het feit, dat uit oudere bladeren van niet te jonge planten een zeer vertraagd virustransport naar de knollen en naar de top van de plant plaats vindt. Dit verschijnsel zou in feite ook ouderdomsrestente genoemd kunnen worden, daar het vrijwel zeker op hetzen de inoculatie reeds in een betreffende blad verkeert nl. op het mome bladeren.

oudere fysiologische conditie dan de jonge bladeren. In zulk een blad zijn dus eerder de voor wit laatste wordt ook bevestigd uit domsresistentie aanwezig dan in jonge. Dit laatste wordt 57 
de proeven van GRÜMMER (1954), die uitwezen dat de versterkte mate van eiwitafbraak in oudere bladeren vroeger inzet dan in jonge. Het is ook daarom waarschijnlijk, dat het door KöHLER (1956) waargenomen verschijnsel bij tabak op ouderdomsresistentie berust. Wij meenden derhalve zijn hypothese over de inactivering van het getransporteerde virus in de stengel bij tabak eveneens op de feiten aangaande de ouderdomsresistentie bij de aardappel te mogen toetsen. 


\section{HOOFDSTUK 5}

\section{ENKELE BIJZONDERE ASPECTEN VAN DE BESMETTING VAN DE KNOLLEN}

\subsection{INLEIDING}

Bij de behandeling van het virustransport in de aardappelplant is tot dusverre in hoofdzaak de kwestie ter sprake gebracht, of het virus na zekere tijd al dan niet in de knollen aanwezig was. Uit enkele proeven werd ook een beeld verkregen van de hoeveelheid virus, die naar de knollen was hetrantal knollen voorzover deze is uitgedrukt in de mate van besmetting vectie heeft echter nog en ogen. De besmetting van de knollen bij primaire inch oogpunt van belang zijn. Het feit, dat niet alle knollen ván knol nog vrij lang na de inoculatie zowel worden besmet en dat zelfs aan een kunnen worden aangetoond, doet nl, terstond de volgende vragen rijzen:

1. Is er verschil in besmetting tussen verschillende knollen in verband met de grootte ervan?

2. Zijn er in een knol plaatsen aan te wijzen, waar het meest frequent virus kan worden aangetoond?

3. Vindt er tijdens de periode na het rooien nog transport van het virus in de

knol plaats?
Over elk van deze punten is nog zeer weinig bekend en daarom werd getracht
(meest alle reeds beschreven) aangaande deze vraagstukken uit verschillende (meest alle reeds bullen worden proeven gegevens hierover te verkrijgen, die in dit hoofdstuk vermeld en besproken.

5.2. HET VERBAND TUSSEN KNOLGROOTTE EN VIRUSBESMETTING

De eerste proeven, waaruit gegevens werden verkregen over het verband tussen knolgrootte en virusbesmetting zijn beschreven in 3.3.3 en 3.3.4 (tabel 10 en 12). In de in 3.3.3 beschreven proef kunnen we de kno ha hoeveel knollen naar het aantal ogen, waarin ze werden gesngeleverd (noemer) en hoeveel maal respectievelijk $1,2,3$ en 4 ogen hebben opleverden (teller), dan krijgen we hierdeze knollen tenminste eén ziek voor de volgende cijfers: $11 / 25$, leverden, voor de $(47 \%)$ en $2 / 2(100 \%)$. Het percentage van de eerstgenoemde groep met één oog wordt sterk beïnvloed door de gegevens van één plant, nl. plant 2 , die 10 dagen na de inoculatie werd gerooid (tabel 10). Afgezien van de gegevens, die betrekking hebben op deze groep, is uit de cijfers op te maken, dat het percentage bij het kleiner worden van de knollen geleidelijk afneemt. Grote knollen hebben dus blijkbaar een grotere kans om met virus te worden besmet dan kleine. 
In de proef, beschreven in 3.3.4 werd van elke plant de grootste, middelgrote en kleinste knol getoetst. De resultaten van de toetsingen van deze knollen waren de volgende. In totaal werden van 300 planten de genoemde drie knollen getoetst; 171 maal werd een geheel zieke nateelt verkregen, 74 maal een gezonde. In 55 gevallen waren een of twee knollen geïnfecteerd. Hiervan was 35 maal de grootste, 38 maal de middelgrote en 18 maal de kleinste besmet. Hieruit blijkt, dat in dit geval de kleinste knol het minste aantal malen was geinfecteerd. De beide andere knolgrootten vertoonden nauwelijks verschil.

Door de knollen, waarover gegevens werden verkregen omtrent de besmetting met X-virus, in te delen in verschillende grootteklassen, gebaseerd op het aantal stukken, waarin zij werden gesneden, konden ook van andere besproken proeven gegevens als bovenstaande worden verkregen. De moeilijkheid was hierbij, dat groepen van vijf planten eigenlijk te klein zijn, daardoor worden $\mathrm{nl}$. de schommelingen in het beeld, dat wordt verkregen, te groot. Daarom zijn in tabel 21 de gegevens van enkele groepen, die op hetzelfde tijdstip waren geïnoculeerd, doch niet tegelijk waren gerooid, van drie proeven vermeld. De keuze van de groepen werd bepaald door de overweging, dat groepen, waarvan de planten een middelmatige besmetting van de knollen te zien hebben gegeven, de geschiktste gegevens bevatten om tot een inzicht in het gestelde probleem te kunnen komen. In tabel 21 is vermeld, aan welke proeven en planten de gegevens zijn ontleend. In het eerste gedeelte van de tabel (proef 3.3.5.1) zijn de gegevens over de vier verschillende rassen in één percentage per knolgroep weergegeven.

De gegevens van de drie in tabel 21 opgenomen series wijzen alle in dezelfde richting en zijn bovendien in overeenstemming met de resultaten van de twee reeds besproken proeven. Zij kunnen als volgt worden samengevat. De besmetting van de knollen, ongeacht het feit, of deze meer of minder waren besmet, vertoont een uitgesproken tendens in deze zin, dat hoe groter de knol, hoe groter het percentage besmette knollen, m.a.w. hoe groter een knol, hoe groter de kans, dat zulk een knol geheel of gedeeltelijk is besmet. Dit feit stemt overeen met wat ook MǘNSTER \& MAYOR (1954) hebben gevonden. Deze auteurs constateerden verder nog, dat naarmate langere tijd na de inoculatie werd gerooid, de verschillen tussen grote en kleine knollen kleiner, werden. Zij vonden b.v. voor de grootste knol op 13 juli, 27 juli en 7 augustus percentages besmetting van respectievelijk $50,0,60,6$ en 88,9 ; voor de kleinste knol waren deze op dezelfde data respectievelijk 18,7, 51,5 en 69,6. Dit is niet te verwonderen, daar bij voortschrijdende besmetting relatief meer kleine knollen alsnog worden besmet. De door MÜNSTER \& MAYOR gepubliceerde gegevens werden uit veldproeven verkregen en hadden betrekking op „viroses graves”, waar-
schijnlijk bladrol- en Y-virus.

De in tabel 21 weergegeven cijfers over de besmetting van de ogen, tonen aan, dat de lijn, die bij de knolbesmetting kon worden geconstateerd, hier in veel mindere mate naar voren komt. Eerder is een tendens aanwezig, dat alle percentages per groep ongeveer op hetzelfde niveau liggen. Dat de percentages van de grootste en de kleinste knollen van dit gemiddelde niveau vrij sterk afwijken, kan als volgt worden verklaard. Het percentage van de grootste knollen ligt te hoog, doordat het hier slechts enkele knollen betreft, die over het algemeen alleen op de laatste rooidatum werden geoogst en dus altijd boven het 


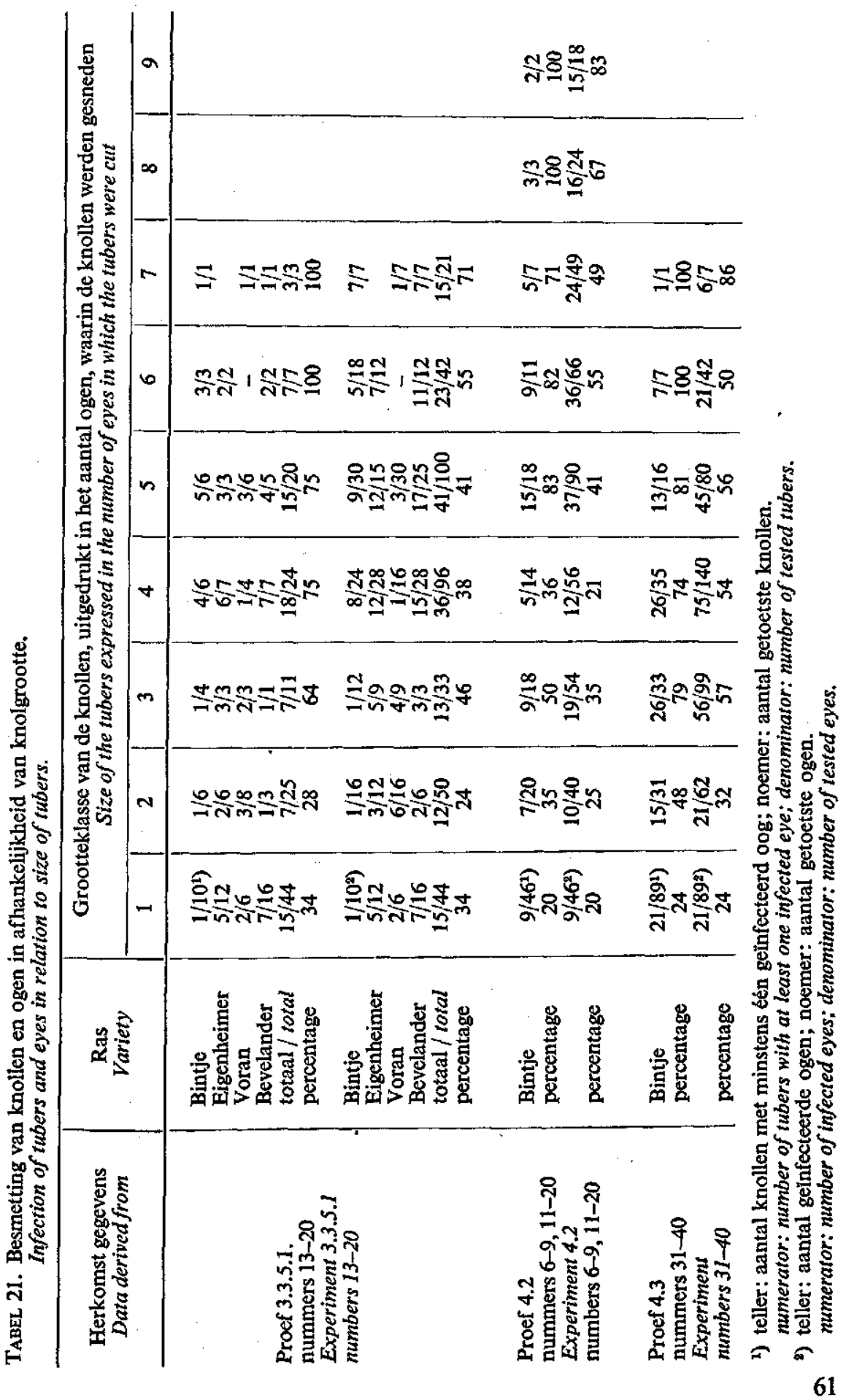


gemiddelde liggen. In de middengroepen speelt deze factor geen rol, omdat hierin op verschillende data gerooide knollen aanwezig zijn. Bij de kleinste knollen heeft dit juist een verlagend effect op het cijfer. Waarschijnlijk is hier bovendien een andere factor in het spel. KRIJTHE (1955) heeft nl. aangetoond, dat de kleinste knollen van een aardappelplant na enige tijd hoegenaamd geen groei meer vertonen en dit heeft waarschijnlijk tot gevolg, dat hierin ook geen virus zal komen.

Enkele factoren hebben dus een misleidende invloed op de verkregen gegevens. Hierdoor zou men tot de onjuiste conclusie kunnen komen, dat de grootste knollen het sterkst zijn besmet en de kleinste het minst sterk, gerekend naar het percentage geïnfecteerde ogen van de knollen. Maar afgaande op de gegevens van de middelgrote knollen - die blijkens bovenstaand betoog het betrouwbaarst zijn - kunnen we wel als zeer waarschijnlijk aannemen, dat het percentage geïnfecteerde ogen bij een juiste proefopzet (d.w.z.: dezelfde inoculatie- en rooidatum voor alle planten en het uitschakelen van de kleinste knollen) voor alle knollen ongeveer gelijk zou komen te liggen. Dit zou betekenen, dat naar elke knol gemiddeld een hoeveelheid virus wordt gevoerd, die evenredig is met het gewicht van de desbetreffende knol.

Deze waarneming heeft een interessant aspect met betrekking tot de beantwoording van de vraag, of het virus passief met de stroom van assimilaten wordt meegevoerd. Het is nl. bekend (KRIJTHE, 1955), dat alle knollen van een plant tegelijkertijd worden aangelegd. Hierna begint de knolgroei, niet alle knollen groeien echter even sterk. Een deel van de knollen in aanleg komt zelfs in het geheel niet tot ontwikkeling. Het resultaat is een verscheidenheid van knolgrootten, wat inhoudt, dat aan iedere knol per tijdseenheid een hoeveelheid aan assimilaten wordt toegevoerd, die evenredig is met het gewicht van de $\mathrm{knol}$ bij het rooien. Daar, zoals is gebleken, ook de hoeveelheid virus, die in de knollen kan worden aangetoond, evenredig is met de grootte van de knol, bestaat er een verband tussen de toegevoerde hoeveelheid assimilaten en de in de knol aanwezige hoeveelheid virus. Dit zou kunnen wijzen op een passief transport van het virus met de stroom van assimilaten. In de literatuur bestaat aangaande dit punt geen volledige eenstemmigheid (zie 2.2). Zowel CRAFTS (1951) als BENNETT (1955), die beiden de literatuur op dit gebied kritisch hebben bezien, achten echter een transport van virus met de stroom van assimilaten het meest waarschijnlijk.

Dat de verdeling van het virus over de knollen van een aardappelplant een evenredigheid met de toegevoerde hoeveelheid assimilaten kan vertonen, is o.i. een bewijs voor het feit, dat het aantal actieve virusdeeltjes, dat de knollen bereikt, zeer klein moet zijn, vooral in verhouding tot het aantal, dat in het geïnoculeerde blad aanwezig is. In de knollen zal dus dit aantal in vele gevallen slechts enkele bedragen, mits we aannemen, dat geen grote hoeveelheden virus op bepaalde plaatsen in de knol zijn geconcentreerd. In het geïnoculeerde blad moeten daarentegen vele honderdduizenden deeltjes aanwezig zijn.

In de in 3.3.3 beschreven proef werd de lengte van de stolon van elke knol bepaald om na te gaan of deze lengte eventueel invloed heeft op de besmetting van de betrokken knol. Klassificeren we in de genoemde proef de knollen naar het aantal ogen, dat ervan werd gesneden en gaan we na, hoe lang de stolon gemiddeld bij elk der groepen is geweest, dan krijgen we voor de knollen met $1,2,3$ en 4 ogen respectievelijk de volgende gemiddelde stolonlengten: 4,2 
$3,6,4,0 \mathrm{en} 2,5 \mathrm{~cm}$. De verschillen bleken niet betrouwbaar en er is dan ook geen invloed van de stolonlengte op de besmetting van de desbetreffende knol aan te wijzen. Aan de hand van de gegevens over de relatie virusbesmettingknolgrootte kunnen we in feite volstaan met de opmerking, dat het effect van de lengte van de stolon slechts van betekenis is, voorzover er verschil bestaat tussen de lengten van de stolonen bij verschillende knolgrootten en is het effect van de eventueel af te leggen langere weg bij langere stolonen van geen enkele directe betekenis.

\subsection{DE PLAATS VAN HET AARDAPPEL X-VIRUS IN PRIMAIR GEINFECTEERDE KNOLLEN}

Met de plaats in de knol wordt hier bedoeld de plaats, voorzover deze samenhangt met het apicale of basale gedeelte van de knol en dus niet het verschil tussen parenchymatisch en vaatweefsel. Bij de reeds beschreven proeven waren de knollen zodanig gesneden, dat zowel het apicale, als het basale gedeelte ervan altijd uit de gegevens over de besmetting van de knollen waren terug te vinden. De plaats van de andere ogen was minder gemakkelijk vast te leggen vanwege de individuele verschillen per knol wat betreft grootte en ligging van de ogen.

Om over een aantal gegevens te kunnen beschikken, werden van enige proeven de resultaten van die knollen nagegaan, die zowel zieke als gezonde ogen hadden opgeleverd. Uit de wiskundige verwerking van de gegevens ${ }^{1}$ ) is komen vast te staan, dat met grote zekerheid het apicale oog meer malen besmet is dan het basale. Van de 381 knollen, waarover de berekening werd uitgevoerd, was 239 maal $(63 \%)$ het apicale oog besmet, tegenover 144 maal $(38 \%)$ het basale oog. Prochal (1953) heeft serologisch, gebruikmakend van de complementbindingsteactie, ook nagegaan waar het X-virus zich in de knol bevindt. Hij stelde eveneens vast, dat het meeste virus aanwezig is in het apicale gedeelte van de knollen.

Het feit, dat het virus het meest frequent in het topoog wordt aangetroffen, kan als volgt aannemelijk worden gemaakt. De aardappelknol groeit hoofdzakelijk aan het topeinde. Naar dit gedeelte zal zich dus in hoofdzaak ook de sapstroom begeven en bijgevolg, naar onze hypothese, ook het virus. $\mathrm{Er}$ ontstaat aldus een concentratie aan virus in het apicale gedeelte van de knol, welk feit dan ook als vaststaand werd waargenomen. Daar alle virus, dat de knol wordt binnengevoerd langs het basale deel moet passeren, is het niet te verwonderen, dat ook altijd een aantal basale ogen ziek wordt bevonden.

\subsection{WAT GEBEURT ER MET HET VIRUS TIJDENS DE BEWARING EN NA HET POTEN VAN DE KNOL?}

Zoals we in vele proeven hebben kunnen constateren, vinden we aan een primair geïnfecteerde aardappelplant knollen, die slechts gedeeltelijk zijn besmet. Daar een aardappelknol tijdens de bewaring na een zekere periode van uiterlijke rust, weer tekenen van groei gaat vertonen (spruitvorming), vragen we ons af, of tegelijk hiermede ook het virus misschien tot meer activiteit komt, resulterende in virusvermeerdering en/of transport. In de beschreven proeven

1) De heer C. A. VAN DEN ANKER wordt hierbij hartelijk dank gezegd voor het uitvoeren van deze berekening. 
was de tijd, die verliep tussen het rooien en het poten niet in alle gevallen gelijk, hetgeen, indien er werkelijk tijdens de bewaring transport van virus in de knollen had plaats gevonden, aanleiding zou kunnen zijn geweest tot enigszins foutieve conclusies.

In de proeven werden de knollen nooit eerder gepoot, dan nadat spruitvorming was begonnen. Wel werd niet altijd direct tot poten overgegaan als dit feit werd geconstateerd. Er zijn dus gevallen geweest, waarbij de knollen gedurende een vrij lange periode in de toestand van spruiting bewaard waren. Toch was de ervaring, dat ook in deze gevallen de partiële besmetting van de knollen duidelijk uit de gegevens bleek, waaruit de conclusie kan worden getrokken, dat, zo er al transport in de knollen mogelijk is, deze niet van grote betekenis kan zijn. Anderzijds echter kan men bedenken, dat bij de inoculatie met behulp van de knolenting wel degelijk transport van virus in de knol moet kunnen plaats vinden om tot een geslaagde inoculatie te kunnen geraken.

Om aangaande deze vraagstukken een uitspraak te kunnen doen, werd in 1957 een proefje uitgevoerd. Op 10 juli werden 30 knollen (Bintje) gepoot, waarna de eruit opgroeiende planten op één stengel werden gehouden. Op 2 september daaropvolgend werd van alle planten een jong blad geïnoculeerd. Daar het tijdstip van de inoculatie in verband met de leeftijd van de planten, vrij laat was gekozen (om over een aantal grote knollen te kunnen beschikken), werden de knollen drie weken na de inoculatie gerooid. Verondersteld werd, dat op deze wijze nog veel knollen werden verkregen, die partiëel besmet waren, hetgeen inderdaad het geval bleek te zijn. De grote knollen van 12 van de planten werden onmiddellijk na het rooien in een aantal stukken verdeeld om hierdoor te voorkomen, dat het virus eventueel van de besmette naar de nog onbesmette gedeelten van de knol zou overgaan. De knollen van de overige 18 planten werden intact gelaten om het virus de mogelijkheid te bieden tot verplaatsing binnen de knol. Op 23 december 1957, na drie maanden bewaring bij kamertemperatuur, werden de stukken van de eerstgenoemde groep gepoot. De andere 18 planten werden in twee groepen verdeeld, een groep van zes en een groep van 12 planten. De knollen van de groep van zes planten werden eind december in stukken gesneden en gepoot om na te gaan, of tijdens de periode tussen het rooien en het poten van de knollen transport van virus binnen de knol was opgetreden. Van de resterende 12 planten werden alle knollen geheel gepoot om na te kunnen gaan of tijdens de periode na het poten transport binnen de knol mogelijk is.

In tabel 22 zijn de resultaten weergegeven, die werden verkregen na toetsing van de planten met Gomphrena globosa.

In deze tabel, derde kolom, is niet opgenomen het aantal getoetste en het aantal geïnfecteerde ogen, daar dit, zoals nog nader zal worden uiteengezet, bepaalde moeilijkheden opleverde. De gegevens van de eerste en de tweede kolom maken een vergelijking mogelijk om te kunnen bepalen of tijdens de bewaring transport in de knollen heeft plaats gevonden. We zien, dat in geen enkel opzicht een belangrijk verschil tussen beide kan worden geconstateerd. Vooral het laatst opgenomen percentage is in dit opzicht belangrijk, daar dit het percentage geïnfecteerde ogen aangeeft van alleen die knollen, waarin werkelijk virus werd aangetoond. Zou er dus binnen de knollen transport van enige betekenis hebben plaats gevonden, dan zou dit in deze percentages tot uitdrukking moeten zijn gekomen. De percentages blijken ongeveer gelijk te 
TABEL 22. De mate van besmetting met $X$-virus van knollen van primair geïnfecteerde planten, die direct na het rooien, vlak vóór het poten of in het geheel niet waren stuk gesneden.

The rate of infection of tubers with potato virus $X$ of tubers from primarily infected plants, which had been cut into pieces directly after harvesting, just before planting or not at all.

\begin{tabular}{|c|c|c|c|}
\hline \multirow{2}{*}{ 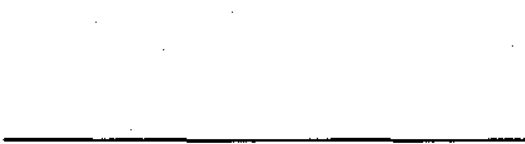 } & \multicolumn{2}{|c|}{ Knollen gesneden / Tubers cut } & \multirow{2}{*}{$\begin{array}{l}\text { Knollen niet } \\
\text { gesneden } \\
\text { Tubers not cut }\end{array}$} \\
\hline & $\begin{array}{l}\text { directna rooien } \\
\text { in the time of } \\
\text { harvesting }\end{array}$ & $\begin{array}{c}\text { vlak vóor poten } \\
\text { in the time of } \\
\text { planting }\end{array}$ & \\
\hline $\begin{array}{l}\text { Aantal planten met geinfecteerde knollen } \\
\text { Numbers of plants with infected tubers. }\end{array}$ & 10 & 6 & 10 \\
\hline $\begin{array}{l}\text { Aantal toetsplanten } \ldots \cdots \\
\text { Number of test plants }\end{array}$ & 12 & 6 & 12 \\
\hline $\begin{array}{l}\text { Aantal getoetste knollen } \ldots \ldots \ldots \\
\text { Number of tested tubers }\end{array}$ & 77 & 48 & 92 \\
\hline $\begin{array}{l}\text { Aantal en percentage geinfect. knollen } \\
\text { Number and percentage of infected tubers }\end{array}$ & $31(40 \%)$ & $18(38 \%)$ & $27(29 \%)$ \\
\hline $\begin{array}{l}\text { Aantal getoetste ogen } \cdots \cdots \\
\text { Number of tested eyes }\end{array} \cdots$ & 255 & 200 & \\
\hline $\begin{array}{l}\text { Aantal en percentage geïnfecteerde ogen. } \\
\text { Number and percentage of infected eyes }\end{array}$ & $90(35 \%)$ & $54(27 \%)$ & \\
\hline $\begin{array}{l}\text { Aantal getoetste ogen van geinfecteerde } \\
\text { knollen } \\
\text { Number of tested eyes from infected tubers }\end{array}$ & 161 & 110 & \\
\hline $\begin{array}{l}\text { Aantal en percentage geïnfecteerde ogen } \\
\text { van geïnfecteerde knollen } \\
\text { Number and percentage of infected eyes } \\
\text { from infected tubers }\end{array}$ & $90(56 \%)$ & $54(49 \%)$ & \\
\hline
\end{tabular}

zijn en we kunnen dus als meest waarschijnlijk aannemen, dat transport binnen de knollen niet is opgetreden.

De resultaten, die werden verkregen met de knollen, die in haar geheel werden gepoot, eisen een speciale beschrijving. De bedoeling van dit gedeelte van de proef was, om alle achtereenvolgens uit de knol opgroeiende scheuten te toetsen, ten einde aldus een inzicht te verkrijgen in de mate van de besmetting van de ogen, waarbij het virus dus de kans werd gegeven, tijdens de periode van het tijdstip van poten tot toetsen naar andere gedeelten van de knollen te worden getransporteerd. Het bleek nu, dat in vele gevallen aanvankelijk slechts het apicale oog van een knol uitliep. Nadat dit oog een scheut had opgeleverd, werd deze getoetst, waarna aan de basis van de oude scheut meestal weer een jonge scheut ontstond, die ook weer werd getoetst. Dit herhaalde zich in vele gevallen verscheidene malen. Hoewel ook enkele andere ogen later scheuten vormden, was het totale aantal ogen, dat in dit gedeelte van de proef kon worden getoetst, toch veel kleiner dan bij de andere proefobjecten. Toch kan uit de resultaten van de uitgevoerde toetsingen een conclusie worden getrokken. Het kwam nl. dikwijls voor, dat een oog enkele malen een gezonde, maar naderhand toch een zieke scheut opleverde. Was eenmaal virus in een bepaald „oog" 
aangetoond, dan bleken ook alle achtereenvolgens verschenen scheuten ziek te zijn. Het tijdstip, waarop aldus bleek, of een knol al dan niet met virus was besmet, varieërde daardoor. Uiteindelijk werden de gegevens over de knolbesmetting verkregen, die in de derde kolom van tabel 22 zijn vermeld. We zien, dat de besmetting over het algemeen in deze groep iets minder was. Dit zou misschien verklaard kunnen worden door aan te nemen, dat in hele knollen niet al het virus een kans krijgt zich te manifesteren. De getallen zijn echter te klein om hierover een uitspraak te kunnen doen.

Het feit, dat het virus in vele gevallen vrij laat in het uitgroeiende oog kon worden aangetoond, wijst er zeer sterk op, dat het virus in de knol wordt getransporteerd na het poten ervan. Dit transport vindt blijkbaar vrij langzaam plaats. In sommige gevallen duurde het vele weken, voordat de scheut besmet bleek te zijn. In een enkel geval was de scheut aan het apicale einde van de knol gezond, doch leverde een ander oog wel een zieke scheut op. Ook dit laatste wijst er op, dat het transport in de knol niet gemakkelijk plaats kan vinden. Toch mag waarschijnlijk wel worden aangenomen, dat onder omstandigheden in de praktijk dikwijls de gehele plant uit een knol zal zijn besmet.

\subsection{BESPREKING VAN DE RESULTATEN}

Bij primaire infectie konden met betrekking tot de besmetting van de knollen de volgende feiten worden vastgesteld. 1. De grootste knollen hebben de meeste kans om met virus te worden besmet. 2 . In de knollen wordt het virus het meest frequent in de apicale ogen aangetroffen. 3. Tijdens de bewaring vindt geen transport van virus in de knol plaats. $\mathrm{Na}$ het poten kan er wel transport binnen de knollen geschieden.

Uit de bovenvermelde drie punten kunnen enkele belangrijke conclusies worden getrokken. Hoewel nl. ook aan grote knollen virusvrije gedeelten kunnen worden aangetoond, duidt het onder punt 3 genoemde feit op de mogelijkheid, dat de uit een grote knol opgroeiende plant geheel ziek zal zijn. Een gevolg hiervan is, dat de resultaten van alle besproken proeven voor praktische beschouwingen het beste bekeken kunnen worden aan de hand van de vermelde gegevens over de besmetting van de knollen. Bij de hierover verstrekte gegevens is er nl. van uitgegaan, dat de desbetreffende knollen of geheel ziek of geheel gezond waren. Zoals reeds eerder werd betoogd, bieden de cijfers over de besmetting van de ogen een betere basis voor theoretische beschouwingen betreffende transport, concentratie van virus e.d.

Een tweede punt, dat naar aanleiding van de resultaten moet worden genoemd, is het volgende. De laatste jaren is een methode van diagnose tot ontwikkeling gekomen, waarmee aan de knollen kan worden nagegaan of deze met virus zijn besmet. Deze zgn. IGEL-LANGE toets berust op een kleuring van callose in de zeefvaten met resoblauw en is in Nederland door de N.A.K. in het bijzonder uitgewerkt ten behoeve van het onderzoek op de besmetting met bladrol van de knollen. Hoewel de door ons gegeven feiten over de besmetting van de knollen het X-virus betreffen, lijkt het gerechtvaardigd om bij het toepassen van een toetsmethode op aardappelknollen met de door ons vermelde gegevens rekening te houden, daar de mogelijkheid van een zekere wetmatigheid, ook met betrekking tot de besmetting van de knollen met bladrolvirus, niet is uitgesloten. De proeven door ons met het bladrolvirus uitgevoerd, laten nog geen conclusies toe aangaande deze feiten. 


\section{ALGEMENE NABESCHOUWING}

\subsection{ENKELE BESCHOUWINGEN BETREFFENDE PRAKTISCHE PROBLEMEN}

De in de voorgaande hoofdstukken verkregen resultaten komen zeer in het kort op het volgende neer. De tijd, die verloopt tussen de infectie van het blad en de infectie van de knollen met aardappel $X$-virus is langer, naarmate de plant ouder is op het tijdstip van de inoculatie. Er treedt al vrij spoedig, waarschijnlijk een à twee weken na het begin van de knolvorming, een periode in, waarin het transport van het virus naar de knollen slechts moeilijk tot stand kan komen. In feite verkeert de plant in deze fase nog in een actief stadium, getuige de grote hoeveelheid reservestoffen, die gedurende deze periode in de knollen worden opgeslagen. Het is dus enigszins verrassend, dat in deze periode geen of althans zeer weinig virus naar de knollen wordt getransporteerd, welk feit in hoofdstuk 4 uitvoerig werd besproken.

Hoewel de meeste proeven werden uitgevoerd onder kasomstandigheden, is uit de beschreven veldproeven niet gebleken, dat zich in het veld feiten voordoen, die principiëel afwijken van het uit kasproeven verkregen beeld van het virustransport. Het is wel de vraag, of de tijdstippen, zoals het begin van de knolvorming e.d. in veldproeven even lang na het poten vallen als in kasproeven. Waarschijnlijk zijn in het veld de perioden tussen poten, aanvang van knolvorming en afrijping langer dan in de kas. Naast deze factoren komen nog andere zoals b.v. het ontwikkelen van zijscheuten en het optreden van secundaire groei, terwijl ook verschillen in de bemestingstoestand van de grond e.d. de ontwikkeling van het gewas kunnen beïnvloeden en daardoor afwijkingen kunnen veroorzaken van het gegeven patroon van de ouderdomsresistentie.

Een zeer belangrijke vraag is: kunnen de met X-virus verkregen resultaten van toepassing worden verklaard op andere aardappelvirussen, zoals b.v. het bladrol-en het Y-virus? Uit hetgeen hierover uit eigen waarnemingen (BEEMSTER, in druk) bekend is, zijn we geneigd, deze vraag bevestigend te beantwoorden. Het bestaan van de ouderdomsresistentie ten aanzien van het bladrolvirus is duidelijk angetoond. Het is echter niet uitgemaakt, of de algemene lijnen, die voor het $\mathrm{X}$-virus konden worden aangegeven, geldigheid bezitten voor alle virussen. Voorzover wij weten, vertonen de verschijnselen van de ouderdomsresistentie ten opzichte van bladrol- X- en Y-virus in grote trekken veel overeenkomst, al weten wij nog niet tot in welk detail dit opgaat. Zo is onbekend, op welk moment de ouderdomsresistentie ten aanzien van bladrolvirus begint op te treden. Wij willen hier echter aannemen, dat de ouderdomsresistentie ten aanzien van de door bladluizen overgebrachte virussen hetzelfde beeld als het $X$-virus vertoont. In het algemeen zou dit betekenen, dat de normaal begin juli verschijnende grote vlucht van de belangrijkste overbrenger van virussen, $\mathrm{nl}$. 
Myzus persicae, optreedt op een tijdstip, waarop de aardappelplant 9 à 10 weken oud is, dat is waarschijnlijk ongeveer het tijdstip, waarop de ouderdomsresistentie begint op te treden. Vergelijken we nl. de ontwikkeling van aardappelen in het veld met die in de kas, dan blijkt, dat de ontwikkeling in het veld trager is. Waarschijnlijk kunnen in het veld groeiende planten van 9 à 10 weken vergeleken worden met planten in de kas, die 7 à 8 weken oud zijn. Zoals uit de tabellen 18 en 20 is gebleken, is het verschijnsel der ouderdomsresistentie bij 7 à 8 weken oude planten zeer duidelijk. Dit betekent, dat in het veld de ouderdomsresistentie zich zal doen gelden van planten van 9 à 10 weken. Het is waarschijnlijk zo, dat een verschil in ontwikkelingsstadium van het gewas van één week in deze periode van doorslaggevende betekenis is voor de gezondheidstoestand van het pootgoed. Dit verschil kan b.v. worden veroorzaakt, doordat de knollen vroeg zijn gepoot of doordat tijdens de eerste periode van de ontwikkeling gunstige weersomstandigheden zijn opgetreden, terwijl tenslotte ook de bladluizen door omstandigheden wat later kunnen optreden. In verband met het optreden van bladluizen is het wel de vraag, of de omstandigheden, die de ontwikkeling van het gewas in gunstige zin beïnloeden, ook niet een gunstige invloed hebben op de ontwikkeling van de bladluizen. Zou dit laatste het geval zijn, dan zijn het vroege poten en het voorkiemen van het pootgoed de meest doeltreffende middelen om de ontwikkeling van het gewas in zo gunstig mogelijke zin te beïnvloeden.

Een ander feit, dat in het oog moet worden gehouden, is het volgende. De eerste bladluizen, die reeds, zij het in kleinen getale, in mei en juni optreden, zouden van niet geringe betekenis kunnen zijn bij de verspreiding van virusziekten in een aardappelgewas, gezien het gemak, waarmede het virus in jonge aardappelplanten kan worden getransporteerd. Bij het opstellen van bespuitingsschema's ter bestrijding van bladluizen (en daardoor ter voorkoming van de verspreiding van virussen) zou met de vroeg optredende bladluizen sterk rekening moeten worden gehouden.

Hoewel het onderzoek naar de basis van bovenstaande beschouwingen over de ouderdomsresistentie ten aanzien van het bladrolvirus nog niet geheel is voltooid en het niet geheel vaststaat, of de feiten zo zijn, als hier is verondersteld, is met het oog op het belang ervan voor de pootaardappelteelt, hier toch op enkele facetten ervan de aandacht gevestigd.

\subsection{ENKELE THEORETISCHE BESCHOUWINGEN}

Bij de inleiding van hoofdstuk 2 (2.1) werden een aantal punten genoemd, die van algemeen belang zijn inzake het virustransport in de plant. Aan de hand van de verkregen resultaten zullen enkele van de genoemde punten aan een nadere beschouwing worden onderworpen.

Naar algemeen wordt aangenomen, vindt het transport van virussen van het mozaïektype in het eerste stadium na de inoculatie vrij langzaam plaats tot het tijdstip, waarop het floëem wordt bereikt. Van dat moment af vindt het transport plaats door het floëem en dit geschiedt met een grotere snelheid dan het transport gedurende de eerste fase. Onze waarnemingen zijn met deze zienswijze geheel in overeenstemming. CAPOOR (1949) heeft voor verschillende virussen uit eigen onderzoek en uit literatuurgegevens bepaalde snelheden voor het transport van verschillende virussen in het floëem berekend. Uit de door hem 
verstrekte cijfers zou de indruk kunnen worden verkregen, dat de snelheid van de door cicadelliden overgebrachte virussen zeer veel groter is dan die van andere virussen. Toch behoeft dit niet het geval te zijn, daar de juiste snelheid van virustransport in het floëem voor virussen, die niet onmiddellijk na de inoculatie het geïnoculeerde blad verlaten, zeer moeilijk kan worden bepaald. Het is nl. nooit met zekerheid te zeggen, op welk tijdstip het virus uit het parenchymatische weefsel van het blad in het fioëem terecht komt. Blijkens de door ons hierover uitgevoerde proeven moet dit tijdstip van plant tot plant verschillend zijn. De voor de snelheid in het floëem aangegeven waarde kan in deze gevallen dus slechts een benadering zijn van de werkelijke snelheid.

Omtrent de richting, waarin het virus in de aardappelplant wordt getransporteerd, kan worden gezegd, dat deze in hoofdzaak wordt bepaald door de leeftijd van de plant en soms ook door de plaats van het geïnoculeerde blad. In het algemeen kon deze richting worden afgeleid uit de richting, waarin op dat moment de heersende stroom van assimilaten zich bewoog. In het stadium van de knolvorming vindt transport van virus b.v. uitsluitend neerwaarts plaats en vóór deze periode bovendien opwaarts (zie fig. 2 en tabel 8).

De vraag, in welke vorm virustransport plaats vindt, is zeer moeilijk te beantwoorden. In de literatuur vinden we hierover weinig gegevens. ZECH (1953) stelt zich voor, dat er ,precursors” van het virus worden getransporteerd, die eventueel op een andere plaats in de plant weer tot complete virusdeeitjes kunnen worden, bv. door recombinatie van verschillende delen. De resultaten van de door ons beschreven proeven leveren geen enkele bijdrage tot het oplossen van het probleem. Wel kan eruit worden afgeleid, dat het vrijwel uitgesloten is om op directe wijze proeven met het $\mathrm{X}$-virus aangaande dit punt uit te voeren. Het is o.i. namelijk onmogelijk de geringe hoeveelheid virus, die door de stengel wordt getransporteerd, aan te tonen in het stadium, dat dit nog zin zou hebben. Als we te lang wachten, bestaat de kans, dat we nieuw, in de stengel zelf gesynthetiseerd virus aantonen, hetgeen dan geen aanwijzing geeft over het getransporteerde virus.

Een belangrijke vraag is tenslotte: hoe vindt transport van virus plaats? Het is nog niet precies bekend hoe stoffen in het floëem worden getransporteerd en er bestaan hierover verschillende theoriëen, die de bekende feiten over het transport van stoffen in het floëem verklaren. Belangrijk hierbij is vooral de vraag, of het protoplasma van het floëem nog een rol speelt. Is dit nl. het geval, dan zou het moeilijk zijn, dit in overeenstemming te brengen met de betrekkelijk grote snelheid, waarmee het virus verplaatst wordt. Een verklaring voor de grote snelheid van het virustransport biedt de massastroomtheorie. Volgens deze theorie wordt een stroom van opgeloste stoffen door het floëem vervoerd, waarbij het protoplasma van het floëem geen directe rol zou spelen. Het is vooral deze theorie, die door verschillende auteurs (CRAFTs, 1951; BENNETT, 1955 ) als het meest waarschijnlijk wordt aangenomen, mede ook in verband met de gegevens die bekend zijn over het transport van virussen. Met de massastroomtheorie is het mogelijk het snelle transport van virus in de plant te verklaren en bovendien zou ze ook in overeenstemming kunnen worden gebracht met de gevonden samenhang tussen stroom van assimilaten en virus. Dit zou nl. inhouden, dat het virustransport op een passieve wijze plaats vindt waarbij het in zekere mate afhankelijk is van de stroom van assimilaten. Een onafhankelijk transport, waarbij geen samenhang met de heersende sapstroom zou 
bestaan, zou duiden op grotere betekenis van de relatie tussen virus en floëemprotoplasma, waarbij de fysisch-chemische eigenschappen van beide bepalend zouden zijn voor het transport. $\mathrm{Nu}$ de samenhang tussen virus en assimilatenstroom waarschijnlijk.is, lijkt een verklaring met behulp van de massastroomtheorie meer voor de hand te liggen. 


\section{SAMENVATTING}

In hoofdstuk 1 werden enige proeven besproken, waarin werd nagegaan, hoeveel tijd er verloopt tussen de inoculatie van het blad en het tijdstip, waarop het aardappel X-virus uit het geinnoculeerde blad wordt getransporteerd. Bij de toetsplanten tabak en Physalis floridana bleek dit ongeveer twee dagen te zijn; bij aardappel aanzienlijk langer, nl. vijf dagen bij vrij jonge planten, terwijl in verschillende proeven het virus niet uit het geïnoculeerde blad werd vervoerd binnen de periode, waarin de proeven werden uitgevoerd. De leeftijd van het blad is hierbij waarschijnlijk een belangrijke factor.

Het transport door de stengel (hoofdstuk 2) verloopt, van het moment af, dat het virus in de stengel anwezig is, zeer snel. Dit transport geschiedt discontinu, d.w.z. er worden in de stengel virusvrije stukken aangetroffen temidden van besmette. Dit is gebleken uit proeven, waarbij de opeenvolgende stukken van een stengel na de inoculatie met het virus werden gestekt en naderhand op de aanwezigheid van virus getoetst. Het transport in opwaartse richting vindt gemakkelijk plaats in jonge planten, in oudere zeer veel moeilijker of in het geheel niet.

Aan een eenstengelige plant kunnen gedurende vrij lange tijd na de inoculatie met X-virus zowel besmette als virus-vrije knollen worden aangetroffen, terwijl ook lang na de inoculatie nog knollen worden gevonden, die partiëel besmet zijn.

Bij oudere planten worden na inoculatie van een blad veel minder snel en uiteindelijk ook in veel geringere mate de knollen met het virus besmet dan bij jonge planten (hoofdstuk 3 en 4). Dit verschijnsel wordt aangeduid met ouderdomsresistentie en kon worden angetoond bij de rassen Bintje, Eigenheimer en Voran. Het late ras Bevelander vertoonde onder de gegeven omstandigheden de ouderdomsresistentie niet. Dit vond waarschijnlijk zijn oorzaak in het feit, dat dit ras op het moment van de inoculatie nog in een fysiologisch jonge conditie verkeerde, wat samenhangt met de laatheid van dit ras. In het algemeen kan worden gezegd, dat de leeftijd van het gewas op het moment van de infectie bepalend is voor de gezondheidstoestand van de nateelt ervan. Den en zelfs in vrij resistentie trad ook op in enkele in het veld uitgevoerde proeven en zelfs in vrij sterke mate.

Een nader onderzoek aangaande de ouderdomsresistentie (hoofdstuk 4) heeft aan het licht gebracht, dat er op het tijdstip van het begin van de knolvorming reeds enige ouderdomsresistentie voorkomt. Een tot twee weken later is de invloed ervan al zeer groot en vindt nog slechts sporadisch transport van virus

naar de knollen plaats.
Nagegaan werd verder of de virusvermeerdering in de geinoculeerde bladeren van planten, die de ouderdomsresistentie vertonen, eveneens vermindert, hetgeen inderdaad het geval bleek te zijn. Toch was de virusproduktie in planten, die de ouderdomsresistentie duidelijk vertoonden, nog geenszins gering.

In de beschouwingen over de achtergronden van deze verschijnselen werden verschillende mogelijkheden onder ogen gezien. Twee punten, die hierbij als zeer 
waarschijnlijk naar voren zijn gekomen, zijn de volgende. Het transport van het X-virus in de aardappelplant verloopt niet zo gemakkelijk als men geneigd zou zijn aan te nemen, d.w.z. slechts een zeer kleine fractie van het in het blad geproduceerde virus wordt getransporteerd. De oorzaak van de ouderdomsresistentie moet worden gezocht in een verandering in de eiwitstofwisseling, die zich voltrekt, naarmate de plant ouder wordt. Dit leidt er waarschijnlijk toe, dat in oudere planten de virussynthese vermindert. Daar het virus vrij moeilijk wordt getransporteerd, leidt een betrekkelijk geringe vermindering van de virusproduktie direct tot een merkbare vermindering van de knolbesmetting.

In hoofdstuk 5 werden enkele facetten van de besmetting van de knollen na primaire infectie aan een nadere beschouwing onderworpen. De grootste knollen bleken het meest frequent met virus te zijn besmet. Dit is te verklaren door een samenhang aan te nemen tussen de stroom van assimilaten en de stroom van virus. Zwaardere knollen krijgen per tijdseenheid meer assimilaten toegevoerd en bijgevolg ook meer virus. In de knollen zelf blijkt het virus belangrijk veel keren meer in het apicale oog dan in het basale oog voor te komen. Tenslotte werd een proefje beschreven, waaruit is gebleken, dat er in de knol tijdens de bewaring geen, maar tijdens de periode na het poten echter wel transport kan optreden.

In een slotbeschouwing (hoofdstuk 6) werd een korte bespreking gewijd aan enkele punten van praktische en theoretische betekenis. 


\section{SUMMARY' ${ }^{1}$ ) \\ TRANSLOCATION OF VIRUS X \\ IN THE POTATO (SOLANUM TUBEROSUM L.) IN PRIMARILY INFECTED PLANTS}

\section{INTRODUCTION}

In the Netherlands the growing of seed-potatoes of high quality, i.e. free from viruses, is facilitated by applying some special measures such as early harvesting, to prevent the infection of tubers. Harvesting at the right time is most important. When it is carried out too late, too many tubers may be infected. On the other hand, when it is done too early, yield may be very low and the tubers too small. In table 1 some figures are given on the rate of growth of some potato varieties around the common date of harvesting. It shows that the daily increase in weight is very large during this period.

Harvesting at the right time is possible when we know: 1 . when the plants are infected and 2. which period is needed by the virus to pass from the leaf, in which it was introduced, to the tubers. To obtain more information about the second question we have carried out investigations on the speed of movement of some potato viruses in potato plants of which those on potato virus $\mathrm{X}$ are given in this paper.

\section{Chapter 1 \\ TRANSLOCATION OF POTATO VIRUS X TULATED LEAVES TO THE TUBERS}

In studying the translocation of viruses in plants, we generally have to consider three steps. 1. Multiplication of virus in the centre of virus-initiation. 2. Translocation from this centre of multiplication to other parts of the plants. 3. Multiplication of translocated virus in the neation is concerned. In experiments, Step 3 is of no importance as far as transit most difficult to diagnose the virus however, we have to keep in mind that it is mocation, because we need relatively when there is no multiplication after tran
big quantities for diagnosis of viruses.

From literature it is known that the period between inoculation and moving out of the inoculated leaf differs, depending on a number of factors such as host, age of the plant, virus and plant species. In our experiments with potato virus X we used White Burley tobacco, Physalis floridana and potato as hosts. To find out at which time the virus moved out of the inoculated leaf, we cut off the inoculated leaves at different intervals after inoculation. Then the plants were allowed to grow till symptoms appeared, which was only the case, when virus had moved out of the leaf. Moreover, in some of the expr

i) The author is greatly indebted to Prof. Dr. G. W. Cochran, Utah State University, Logan, Utah, for correcting the English text. 
compared the sensitivity of some common methods of diagnosing virus $X$. In table 2 it is shown that the serological method is less sensitive than testing with Gomphrena globosa. Gomphrena globosa is not sensitive enough to diagnose virus $X$ in the early stages of infection. In this case the virus could be detected with Gomphrena globosa two days after the moment that it had really moved out of the inoculated leaf. Table 3 presents the results of an experiment in which we tested plants serologically with and without the inoculated leaf; two or three days after the inoculation the virus concentration in the inoculated leaf is apparently sufficiently high to cause a positive reaction after mixing with sap from the healthy parts of the plants. From tables 2 and 3 it can be concluded that the virus moved out of the leaves of White Burley tobacco two to three days after inoculation. The results of similar experiments with Physalis floridana (tables 4 and 5) show that in this plant the virus moved out within 40 to 48 hours. Diluting the inoculum before inoculation does not lengthen this period considerably as can be concluded from table 5 . When virus $X$ moves out of the inoculated leaf of Physalis floridana the concentration of virus in the leaf is relatively low and rises considerably afterwards as is shown in table 6. The experiments, in which potato was used as a host, to find out when the virus moved out of the inoculated leaf, did not give conclusive results. In one of the experiments in which plants were used 28 days after planting, the virus moved out of the inoculated leaf between the fifth and sixth day after inoculation of a leaf in the top of the plant. This period is markedly longer than in White Burley tobacco and Physalis floridana. In the same experiment it was proved that the concentration of virus in the inoculated leaves had reached a considerable titer at the moment of moving out of the leaf as was shown by the local lesion test with Gomphrena globosa. Thus there is evidence that, before entering the stem, the virus is present in a higher concentration in potato than in Physalis fioridana. Other explanations are also possible as e.g. the presence of inhibitors, by which the estimation of the concentration in different plants is not comparable. In two more experiments no translocation out of the leaves was found, which must probably be ascribed to the fact that the plants were too old at the time of inoculation.

\section{Chapter 2}

\section{TRANSLOCATION OF POTATO VIRUS $X$ IN THE STEM OF POTATO PLANTS}

The translocation of potato virus $X$ in the stem of potato plants was studied by making a series of cuttings from the stems of inoculated plants at different intervals. The cuttings were made to be sure that any virus particle that might be present in a given piece of stem had the oppertunity to multiply. Using this method, the presence of virus can easily be detected by testing the plants grown from the cuttings. In a previous paper (BEEMSTER, 1954) the results of some experiments, carried out in this way, have been reported. From these the following facts can be mentioned. After inoculating a young leaf in the top of young plants virus translocation was very rapid down the stem. Inoculation of a leaf at the base of the stem on plants of the same age resulted in a much slower transport to the tubers than when apical leaves were inoculated. Moreover the virus did not move upwards within 30 days. Inoculating the tops of plants, 
which were two weeks older than the group just mentioned, delayed virus translocation to the tubers. Inoculating similar plants on a basal leaf seldom gave rise to any tuber infection, nor did the virus move upwards.

In fig. 1 the results of a similar experiment are shown. This experiment was carried out with very young plants which were inoculated in the tops. From the first until the eighth day after inoculation five plants were cut into five or six pieces daily. The results show that the virus stayed three to four days in the inoculated leaf, then could be detected in the apical part of the stem, after which it was transported to the lower part of the plant within a very short time. The rate of speed of translocation in the stem was rather high in comparison with the time needed by the virus to move out of the inoculated leaf. In some cases it has been found (fig. 1) that virus passed a part of the stem without giving rise to infection. The same was shown in earlier experiments (BEEMSTER, 1954) and also by other authors. It may be an indication that virus translocation within the stem takes place discontinuously and that relatively few virus particles are transported.

An experiment carried out in the same way, in which rather young plants were inoculated on a basal leaf, showed that virus movement up the stem was very rapid. Apparently virus movement up the stem does occur when plants are used which have not yet reached the stage of tuber formation.

As was shown earlier (BEEMSTER, 1954) the position of the inoculated leaf is very important in a study of the translocation of virus in plants. An experiment was carried out, in which leaves were inoculated with virus $X$ at four different levels of Voran potato plants. The tubers were harvested 12,19 and 26 days after inoculation. At the time of harvesting the top of each plant was tested with Gomphrena globosa. The results of this experiment are given in fig. 2 and table 7; fig. 2 shows whether virus translocation was observed upward or downward or in both directions. The translocation of virus downward could be detected by testing the tubers; the results of those tests are niven in tepenFrom these results we can conclude that virus movement was the plants used were too dent on the position of the inoculated leaf. Prostage in which the phenomenon young and the leaves had not yet reach the percentage of tuber infection is highest after inoculating basal leaves which seems to be in contradiction with the results of earlier experiments with Bintje.

In the last part of chapter 2 an experiment is described, in which one leaf each of Bintje potatoes was inoculated when plants were rather young. At different intervals after inoculation series of successive leaves from each of the plants were tested with Gomphrena globosa to find out whether virus X could be detected in those leaves. The results are given in table 8. Apparenty the position of the inoculated leaf determines considerably the path, along which in which the is translocated. This is shown clearly by comparing the thults it can be concluded plants were inoculated at different levels. From the obtain most reliable data concerning the presence of virus in primarily infected plants. 
Chapter 3

\section{TRANSLOCATION OF POTATO VIRUS $X$ FROM THE INOCULATED LEAF TO THE TUBERS}

In chapter 3 some experiments are described in which the infection of tubers in relation to the time of inoculation was studied in detail. In the first experiment which was performed in the glass house 100 potato plants were inoculated in the top 61 days after planting. From the second until the eleventh day after inoculation ten plants were harvested each day. All tubers obtained were - if possible - cut into a number of pieces with eye (in the tables indicated as eyes), which were potted in order to test the plants. The results are given in tables 9 and 10. Table 9 gives the number of plants with at least one infected tuber and the number and percentage of infected eyes. Table 10 presents the detailed results from those plants, in which transport of virus to the tubers was observed. Five days after inoculation virus was detected in the tubers in only one plant. During the next few days the number of plants with infected tubers did not increase very much. Probably the plants used in this experiment were too old to give rise to tuber infection within the period the experiment was carried out. From table 10 we see that when the virus did reach the tubers, not all tubers from one plant were infected and even some of the tubers were only partially infected.

In the field an experiment was carried out in which Bintje potatoes were inoculated with virus $X$ in different stages of their development. Groups of 15 plants were harvested three and five weeks after the inoculation respectively. The design of the experiment is given in table 11. From each plant three tubers were tested. The results are given in table 12 . We see that the older the plants are at the moment of inoculation, the fewer the number of tubers that became infected. This phenomenon is called mature plant resistance. However, this resistance does not give full protection against the infection of tubers. It is shown that some virus was translocated into the tubers from the third till the fifth week even in plants inoculated late in the season.

From series $\mathrm{C}$ in which the plants of each group were inoculated at weekly intervals and were all harvested July 21 , we see that some translocation of virus to the tubers could be demonstrated even when plants were inoculated 11 days before harvesting.

In the same experiment leaves at different levels of the plants were tested with Gomphrena globosa on the day of harvesting. The results of testing leaves from the top, middle and lower parts of the plants are given in table 13. As is shown, virus moves readily up and down to other leaves in young plants, but in plants that were inoculated in a late stage of development, virus could be detected only in a few cases in other leaves.

To find out whether there are differences as for the speed of virus translocation and mature plant resistance among different potato varieties, an experiment was carried out with the varieties Bintje, Bevelander, Eigenheimer and Voran. Groups of 20 plants of the varieties mentioned were inoculated on July 13 and 27 respectively. Four plants of each variety were harvested 2, 4, 6, 8 and 10 days after inoculation respectively. After testing all eyes of the tubers, the results, given in appendix 3.3.5.1 were obtained, which are summarized in table 14. After inoculation on July 13, virus translocation proved to be most 
intensive in the varieties Bevelander and Eigenheimer. In Voran only a small part of the eyes proved to be infected. In case the plants were inoculated on July 27 , translocation of virus to the tubers was only found in Bevelander. In the varieties Bintje, Eigenheimer and Voran only few tubers were found to be infected within ten days after inoculation. From these results it can be concluded that Bintje, Eigenheimer and Voran showed mature plant resistance, however, Bevelander did not. The latter must be attributed to the fact that Bevelander is a late variety, which had not reached the stage, in which mature plant resistance to virus $\mathrm{X}$ occurs. In fact, Voran is a late variety too, but apparently this variety shows some resistance to virus $X$ and therefore mature plant resistance may already appear in an earlier stage of development than in Bevelander.

The experiment was partly repeated in the autumn of 1955. In this experiment we harvested plants from the 3 rd till the 43 rd day after the inoculation. In appendix 3.3.5.2 the results are given in detail and are summarized in table 15. It is shown that in this case virus translocation to the tubers was not as quick as in the foregoing experiment. This must be attributed to the fact that the experiment was carried out in autumn. In this experiment the varieties Eigenheimer, Bintje and Voran showed relatively the same speed of translocation to the tubers as was found in the first experiment with the same varieties, transport being most intensive in Eigenheimer and less intensive in Voran. In Bevelander virus translocation was very poor. This is not in agreement with the results given in table 14, which showed a very intensive translocation of virus $X$ in Bevelander. It is not easy to give a reliable explanation for this fact, maybe circumstantial conditions affect Bevelander in quite another way than they do other varieties.

In 1954 an experiment was carried out to investigate translocation of virus $X$ and the rate of mature plant resistance in the field in the varieties Bintje and Bevelander. Plants of these varieties were inoculated at three different dates at weekly intervals. The first inoculation was carried out 61 days after planting and the plants were harvested from the 3rd till the 23rd day after inoculation. From each plant three tubers were tested. The results are given in table 16, which shows that infected tubers only were found in few cases. Probably this must be ascribed to the fact that the plants had reached the stage of development in which mature plant resistance predominates.

In table 17 the results are summarized of the experiments described so far. It is shown clearly that the older the plants are at the moment of inoculation, the lesser the percentage of infection. In this respect Bevelander shows an irregularity, which was already mentioned earlier.

\section{Chapter 4}

SOME FURTHER INVESTIGATIONS ON MATURE PLANT RESISTANCE

To find out at which time of development of the potato mature plant resistance appears, an experiment was carried out in 1956. Of a group of 80 plants stem and tuber growth were measured, the data of which are given in fig. 4 . It shows clearly that growth of tubers starts when the stem growth stops. At weekly intervals groups of 20 plants were inoculated with virus $X 38,45,52$ and 59 days after planting respectively. From each group five plants were harvested $5,10,15$ and 20 days after inoculation respectively. In fig. 4 the moment of 
inoculation for each group is indicated by A, B, C and D. Before potting, the tubers of the plants were cut into a number of pieces. After testing with $G$. globosa the results were obtained which are given in appendix 4.2 and are summarized in table 18; fig. 5 shows the percentages of infection of the eyes graphically. It is shown that mature plant resistance was already detected in series $B$. The plants in series B were inoculated at the time that the length of the stem did not increase and tuber formation just started as is shown in fig. 4. In series $\mathrm{C}$ a somewhat higher percentage of infected eyes was found but the plants in series D only showed very little transport of virus to the tubers. From this experiment it can be concluded that mature plant resistance appears from the moment tuber formation starts; when plants are inoculated two weeks after the beginning of tuber formation hardly any infection of the tubers was found within 20 days after inoculation.

In 4.3 an experiment is described in which we investigated whether virus reproduction of virus $X$ in potato leaves decreases when the leaves grow older. Four groups of 20 potato plants (Bintje) were inoculated 29, 36, 43 and 50 days after planting respectively. Of each plant three leaves were inoculated viz. one at the top, one at the middle region and one at the base of the plants. From the plants inoculated at the given times the inoculated leaves of five plants were cut off $4,7,11$ and 14 days after inoculation respectively. The five leaves of the top, middle and basal end of the stem respectively were expressed together and the juice of each of the leaf groups was tested with G.globosa. The number of lesions obtained on five leaves of G.globosa are given in table 19 and fig. 6. The results show clearly that the older the plants at the moment of inoculation the smaller the number of lesions that was obtained. Thus virus reproduction in leaves of potato decreases as the leaves grow older. There are no great differences among leaves at different levels of the plant, only the top leaves gave a distinctly smaller number of lesions after inoculation 29 days after inoculation.

At the same time the leaves of five plants were tested, the tubers of those plants were harvested to see whether mature plant resistence appeared. Tre tubers were tested in the same way as was done in the foregoing experiment. The results concerning infection of tubers and eyes are given in appendix 4.3 in detail and are summarized in table 20 . The infection of the eyes is presented in fig. 7. We see that the results are in close agreement with those given in table 18 and fig. 5. Moreover a relationship can be shown between the rate of virus multiplication in the inoculated leaves and the rate of tuber infection.

The results of these experiments lead to the following considerations. When a rather large number of lesions on G.globosa is obtained, as e.g. in the series $B$ and $C$ (fig. 6) we may assume that big quantities of virus are present in the inoculated leaves. Yet the amount of infection of the tubers is relatively low. Even in series A (fig. 7 and 8 ) the large concentration of virus in the inoculated leaves did not give rise to $100 \%$ infection within 14 days after the inoculation. This may be an indication that only a very small number of virus particles of those, which are present in the inoculated leaves are transported. Otherwise the rate of tuber infection had to be higher.

Now the question arises, how it is possible that from the enormous quantity of virus particles present in the inoculated leaves, only a very small number are translocated. There are two possible explanations. 1 . The virus only passes from the cells in which it multiplied to the sieve tubes very occasionnally. 2 . The virus is 
inactivated in the sieve tubes in some way during transport, especially in the stems of old plants. In our opinion the first theory explains best most of the facts concerning translocation of virus and mature plant resistance. A striking example of a fact, which can be explained best by the first, is the following. When the top of a potato plant is cut off, a new shoot grows out. When leaves of such a shoot are inoculated, the tubers of the plant become infected very strongly within a short time. After inoculation of a similar plant on a normal leaf, transport to the tubers seldom occurs. This has to be attributed to the difference in the rate of multiplication in both leaves, but it shows clearly that the inactivation in the stem of such a plant is not of interest as is suggested by the second theory.

The experiments described so far in this chapter gave some information on the nature of mature plant resistance, but did not give any indication concerning the primary cause of the phenomenon. According to GRÜMMER (1954) there is a decrease in proteins in potato leaves from the moment tuber formation starts. Moreover this decrease starts earlier in old leaves than in young ones. It is likely that at the moment protein synthesis decreases, the reproduction of virus also decreases. A decrease in the rate of virus multiplication gives rise to a decrease in the rate of virus translocation to a marked degree, as was pointed out in the foregoing discussion. It is most probable that mature plant resistance must be considered in relation to the metabolism of proteins in the potato.

\section{Chapter 5}

\section{SOME PARTICULARS ABOUT THE INFECTION OF TUBERS}

As was shown in most of the experiments described in the foregoing chapters, healthy and partially infected tubers are always found as a result of primary infection. For some reasons it is of interest to know, which tubers of a plant are infected most likely and to which part of a tuber virus is translocated. Further on it is of interest to know, whether virus translocation within the tuber is possible during storage and after planting of the partially infected tuber. From the results of the experiments already described it was possible to obtain some information concerning these questions.

To find out, which tuber is infected most frequently, we have classified the tubers of some of the experiments according to the number of eyes, which were cut from these tubers. The number of eyes gives more or less a good estimation of the size of a tuber in comparison with other tubers. In table 21 we listed the results of the infection of the tubers and of the eyes from some of the experiments which were described already, as is indicated in the table. We summarized the results from plants which were inoculated at the same time, but were harvested at different periods after the inoculation. From the data of tuber infection which are based on the fact, whether a tuber had at least one infected eye or was not infected at all, it can be concluded that the biggest tubers are most frequently infected. On the other hand, when we compare the percentages of infection of the eyes of each group of tubers, we see that there is a tendency to the same percentage for all groups, with the exception of the biggest and smallest tubers. The biggest tubers were obtained from plants harvested at the last data and thus have a higher percentage of infection than those in the groups in which tubers of all dates of harvesting can be found. The reverse 
holds for the smallest tubers, those were harvested for the greater part at the first date of harvesting and here the percentage of infection is lower than in the middle groups. When we exclude the biggest and the smallest tubers, we see that in the remaining groups there are no great differences among the percentages of infected eyes. This may be an indication that per weight unit an equal quantity of virus is transported to the tubers and that there is some relationship between transport of virus and of assimilates.

From a number of 381 tubers, which were found to be partially infected, the apical eye was infected 239 times $(63 \%)$ whereas the basal eye only 144 times $(38 \%)$. This difference proved to be highly significant. From this we can conclude that the apical part of a tuber is most frequently infected with virus $X$.

An experiment was carried out from which some data were obtained concerning translocation of virus within the tuber. Tubers of three groups of plants, which were harvested three weeks after inoculation with virus $X$, were cut into pieces directly after harvesting, just before planting and not at all, respectively. After testing the pieces (eyes) of the first two groups, the results given in table 22 were obtained. It is shown that virus translocation during storage (at room temperature) did not occur. From the data obtained from testing the shoots growing out of those tubers, which were planted as whole tubers, we learned that virus translocation within the tuber is possible, but there are cases in which virus did not move from one eye to another.

The facts concerning questions, discussed in this chapter, are of interest for the diagnosis of viruses within potato tubers.

\section{Chapter 6 \\ GENERAL DISCUSSION}

Some of the results given in this paper are of importance for seed potato growing. It is very important to know, whether the results, which were obtained with virus $X$ are the same for viruses such as leaf roll and $Y$. We carried out investigations with those viruses on translocation and from these we learned that mature plant resistance can be shown in potato plants with respect to leaf roll and $Y$ too (BEEMSTER, in press). This might be very important, for at the moment aphids appear in big quantities under climatological conditions predominating in the Netherlands, the plants have reached almost the stage in which mature plant resistance is present. It must be considered to be very important to promote the development of growth by early planting, presprouting and others. Moreover secondary growth must be considered as very dangerous, because transport of virus from young growing shoots to the tubers is very rapid. Aphids which appear early in the season, possibly are of importance for the spread of viruses and therefore spraying with chemicals to kill aphids has to be carried out in an early stage of development of the plants.

The speed of translocation of virus in the stems of plants of those viruses such as virus $X$ can not be estimated very exactly, because we do not know, when the virus enters the stem after the first stage of multiplication. The rate of speed of virus translocation in the phloem possibly is much higher than is generally assumed (CAPOOR, 1949) because the given data only give a minimum rate of speed. 
We have not carried out experiments concerning the path along which the virus is moving within the stem. However, from the fact that there is evidence that movement of virus $X$ and of assimilates are connected, it may be concluded that transport of virus is going on through the phloem.

The direction of virus translocation is, according to the results of our experiments very much dependent on the flow of assimilates in the stem. In young plants, we always found translocation both up- and downwards. In older plants, however, translocation often was found only downwards.

The question, in which form virus translocation takes place is difficult to answer. It must be very difficult to obtain information about this with virus $X$ in potato, because the virus most probably is translocated in a very low concentration. This must be too low to diagnose it and to see in which form it is transported in the stem. 


\section{LITERATUUR}

ANONYMUS, - 1955. Opbrengst en sortering van aardappelen bij verschillende rooidata. Landbouwk. Onderz. in de Noord-Oost Polder: 63-73.

ARENZ, B., - 1956. Die Ausbreitung der Viruskrankheiten (Blattroll- und Strichelkrankheit) der Kartoffel in Abhängigkeit von der Sorte und Umweltbedingungen. Bayer. landw. Jahrb. 33: 657-674.

AUGIER DE Montaremier, H., - 1954. Recherches sur la rapidité de migration du virus de l'enroulement en directions des tubercules de pommes de terre. C. R. Acad. Agr. de France 40: 663-666.

BARTELS, R., - 1955. Serologische Untersuchungen über die Konzentration des X-Virus in Kartoffelstauden während der Vegetationsperiode. Phytopath. Z. 24: 421-424.

BeEmster, A. B. R., - 1954. Virustransport innerhalb der Kartoffelpflanze. Mitt. biol. Bundesanstalt Berlin-Dahlem 80: 136-140.

Beemster, A. B. R., - in druk. Some aspects of mature plant resistance in the potato. Proc. 3rd Conf. Pot. Virus Diseases. Lisse-Wageningen, 1957.

BeEMSTER, A. B. R., - in druk. The translocation of some viruses in Physalis floridana. IV. Intern. Pflanzensch. Kongress, Hamburg, 1957.

BENNETr, C. W., - 1934. Plant-tissue relations of the sugar-beet curly-top virus. J. agr. Res. 48: 665-701.

BENNETT, C. W., - 1937. Correlation between movement of the curly-top virus and translocation of food in tobacco and sugar-beet. J. agr. Res. 54: 479-502.

BENNETT, C. W., -1940 . The relation of food translocation to the movement of the virus of tobacco mosaic. J. agr. Res. 60: 361-390.

Bennett, C, W., - 1956. Biological relation of plant viruses. Ann. Rev. PI. Phys. 7: 143-170.

BerCKs, R., - 1949. Uber das Verhalten verschiedener X-Virusherkunfte bei Infektionsversuche an mehreren Kartoffelsorten, (vorläufige Mitteilung). Nachr.-Bl. biol. Zentralanstalt Braunschweig 1: 171-173.

BERCKS, R., - 1950a. Infektionsversuche mit verschiedenen X-Virusherkunften an mehreren Kartoffelsorten. Züchter 20: 282-287.

Bercks, R., - 1950b. Uber die X-Virusverseuchung des Nachbaues von primär infizierten Kartoffelsorten. Nachr.-Bl. dtsch. Pflanzenschutzd. (Braunschweig), 2: 147-149.

BERCKS, R., - 1951. Weitere Untersuchungen zur Frage der Altersresistenz der Kartoffelpflanzen gegen das X-virus. Phytopath. Z. 18: 249-269.

BerCKs, R., - 1952. Fortgeführte Freilanduntersuchungen über die Altersresistenz von zwei Kartoffelsorten gegen das X-Virus. Züchter 22: 85-92.

BERCKS, R., - 1954. Untersuchungen über Änderungen des Virusgehaltes in Tabakpflanzen während der Vegetationsperiode. Phytopath. Z. 22: 215-226.

Bercks, R. \& Gertrud QUerfurt, - 1956. Uber Konzentration und Verhalten des X-Virus in alten Blättern. Phytopath. Z. 26: 35-40.

Bradley, R. H. E. \& R. Y. GaNoNG, -1953 . Note on the time potato leaf roll virus takes to pass from aphids in the leaves into the developing tubers. Can. J. Bot. 31: 143-144.

BöNtNG, K., - 1928. Beiträge zum Studium der Infektionsvorgänge pflanzlicher Viruskrankheiten. Z. Parasitenk. 1: 198-230.

BroAdBenT, L. \& P. H. Gregory, - 1948. Experiments on the spread of rugose mosaic and leaf roll in potato crops in 1946. Ann. appl. Biol. 37: 640-650.

Broadbent, L., P. H. Gregory \& T. W. Tinsley, - 1952. The influence of planting date and manuring on the incidence of virus diseases in potato crops. Ann. appl. Biol. 39: 509-524.

Caldwell, J., - 1934. Physiology of virus diseases in plants. V. The movement of the virus agent in tobacco and tomato. Ann. appl. Biol. 21 : 191-205.

CAPOOR, S. P., -1949 . The movement of tobacco mosaic viruses and potato virus $\mathrm{X}$ through tomato plants. Ann. appl. Biol. 36: 307-319.

CRAFTS, A. S., - 1951. Movement of assimilates, viruses, growth regulators and chemical indicators in plants. Bot. Rev. 17: 203-284.

DierCKs, R.,- 1953. Der Einflusz der Mineralsalzernährung auf Wanderungs- und Ausbreitungsgeschwindigkeit des X-Virus in der Kartoffelstaude. Z. Pflanzenbau 4: 252-258. 
Dykstra, T. P., - 1941. Factors influencing the movement of viruses in the potato. Abstr. Phytopath. 31: 7.

ElzE, D. L., - 1927. De verspreiding van virusziekten van de aardappel (Solanum tuberosum L.) door insecten. Meded. 32 Inst. Phytopath. Lab. Myc. Aardappelonderzoek. Wageningen. Fulton, R., - 1941. The behavior of certain viruses in plant roots. Phytopath. 31: 575-598. GRAINGER, J., - 1933. The movement of tobacco mosaic virus in its host. Ann. appl. Biol. 20: 236-257.

GrÜMMER, G.,-1955. Die Beziehungen zwischen dem Eiweiszstoffwechsel von Kulturpflanzen und ihrer Anfälligkeit gegen parasitische Pilze. Phytopath. Z. 24: 1-42.

GREGORY, P. H., - 1943. The spread of potato virus diseases in the field. Ann. appl. Biol. 30: 104-105.

HARRISON, B. D., - 1956. The infectivity of extracts made from leaves at intervals after inoculation with viruses. J. gen. Microbiol. 15: 210-220.

KassanIs, B., - 1950. Heat inactivation of leaf roll virus in potato tubers. Ann. appl. Biol. 37: 339-341.

KASSANIS, B., -1954 . Heat therapy of virus-infected plants. Ann. appl. Biol. 41 : 470-474.

KöHLER, E., - 1938. Die Bedeutung der Insekten für den Kartoffelbau. Mitt. biol. Reichsanstalt 58: 29-36.

KöHLER, E., - 1947. Uber die Vermehrungs- und Ausbreitungsgeschwindigkeit des X-virus im Blattparenchym. Z. Naturforschung 2b: 29-34.

KöHLER, E., -1955 . Weitere Beiträge zur Kenntnis des Y-Virus der Kartoffel. Phytopath. Z. 23: 328-333.

KöHLER, E., - 1956. Uber die Ausbreitung von Mosaikviren in der Tabakpflanze. I. Das Verhalten der Kartoffelviren X und Y. Phytopath. Z. 26: 147-160.

KRUTHE, N., - 1955. Observations on the formation and growth of tubers of the potato plant. Neth. J. agr. Sci. 3: 291-304.

KUNKEL, L. O., - 1939. Movement of tobacco mosaic virus in tomato plants. Phytopath. 29: 684-700.

Marcus, O., - 1952. Uber die Y-Virusverseuchung der Knollen primär infizierter KartoffelPflanzen. Phytopath. Z. 20: 121-132.

MÜNSTER, J., - 1954. La valeur de la plantation tardive des pommes de terre pour la production du plant. Rev. rom. Agric. Vitic. Arboric. 10: 79-81.

MüNSTER, J. \& G. MAYOR, - 1954. Contribution à l'étude de la détection des maladies à virus de la pomme de terre par indexage (tubercule-test). Extrait du Rapport d'activité 1953 des Stations fédérales d'essais agricoles, Lausanne. Ann. agron. de La Suisse. 55: 915-1047.

MURPHY, P. A. \& R. MCKAY, - 1926. Methods for investigating the virus diseases of the potato and some results obtained by their use. Sci. Proc. roy. Dubl. Soc. 18 (N.S.): 169184.

NiENHAUS, $F_{.,}-1957$. Untersuchungen über den Einflusz von Temperatur und Licht auf die Empfänglichkeit der Pfianzen für das Kartoffel-Y-Virus. Phytopath. Z. 30: 189-224.

Paul, H., - 1955. Untersuchungen über die Brauchbarkeit von Gomphrena globosa für quantitative Teste. Proc. 2nd Conf. Pot. Virus Diseases. Wageningen-Lisse. 1954: 157159.

Prochal, P., - 1953. The distribution of virus $X$ in potato tubers. Polskie Towaz. Bot. Acta Agrobot. 1: 33-77. Agrobot. 1: 33-77.
RoBeRTs, D. A., -1952 . Independent translocation of sap-transmissible viruses. Phytopath.
42: 381-387.

SAMUEL, G., - 1934. The movement of tobacco mosaic virus within the plant. Ann. appl. Biol. 21:90-111.

STAPP, C. \& O. MARCUS, - 1943. Serologische Untersuchungen am Tabak über Ausbreitung und Verteilung der drei Kartoffelviren X, Y und A. Zbl. Bakt. 2: 369-405.

STEERE, R L - 1952. Virus increment curves obtained from counts of particles in clarified plant juice. Am. J. Bot. 39: 211-220.

Storey, H. H., - 1928. Transmission studies of maize streak disease. Ann. appl. Biol. 15: $1-25$.

YARWOOD, C. E., - 1952. Latent period and generation time for two plant viruses. Am. J. Bot. 39: 613-618.

ZECH, H., - 1952. Untersuchungen über den Infektionsvorgang und über die Wanderung des Tabakmosaikvirus im Pflanzenkörper. Planta 40: 461-514. 


\section{AANHANGSEL $A P P E N D I X$}

Prokf 3.3.5.1. Het transport van aardappel $X$-virus van het geĭnoculeerde blad naar de knollen bij verschillende aardappelrassen.

Experiment 3.3.5.1. The translocation of potato virus $X$ from the inoculated leaf to the tubers in different potato varieties.

De knollen zijn gepoot op 5 juni 1954. Van de nummers $1 \mathrm{t} / \mathrm{m} 20$ (20a) van elk ras is van elke plant een volgroeid blad in de top van de plant geinoculeerd op 13 juli 1954 . De nummers $21 \mathrm{t} / \mathrm{m} 40$ (40a) werden op dezelfde wijze geinoculeerd op 27 juli 1954. Het rooien van telkens vier (soms drie of vijf) planten geschiedde in beide gevallen twee, vier, zes, acht en tien dagen na de inoculatie. De resultaten zijn per knol per plant weergegeven. Van iedere knol is het aantal getoetste ogen aangegeven (noemer) en het aantal ogen van die knol, dat na toetsing ziek bleek te zijn (teller). De knollen zijn geplaatst in volgorde van grootte: van links naar rechts nemen de knollen in grootte af.

The tubers were planted 5 June 1954. Of the numbers 1-20 (20a) of each variety one fullgrown leaf in the top of each plant was inoculated at 13 July 1954. The numbers $21-40$ (40a) were inoculated in the same way 27 July 1954. In both cases four (sometimes three or five) plants of each variety were harvested two, four, six, eight and ten days after the inoculation. The results are given per tuber per plant. Of each tuber the number of tested eyes (denominator) and the number of diseased eyes (numerator) are given. The tubers are given in order of size: the biggest tuber being at the left, the smallest at the right.

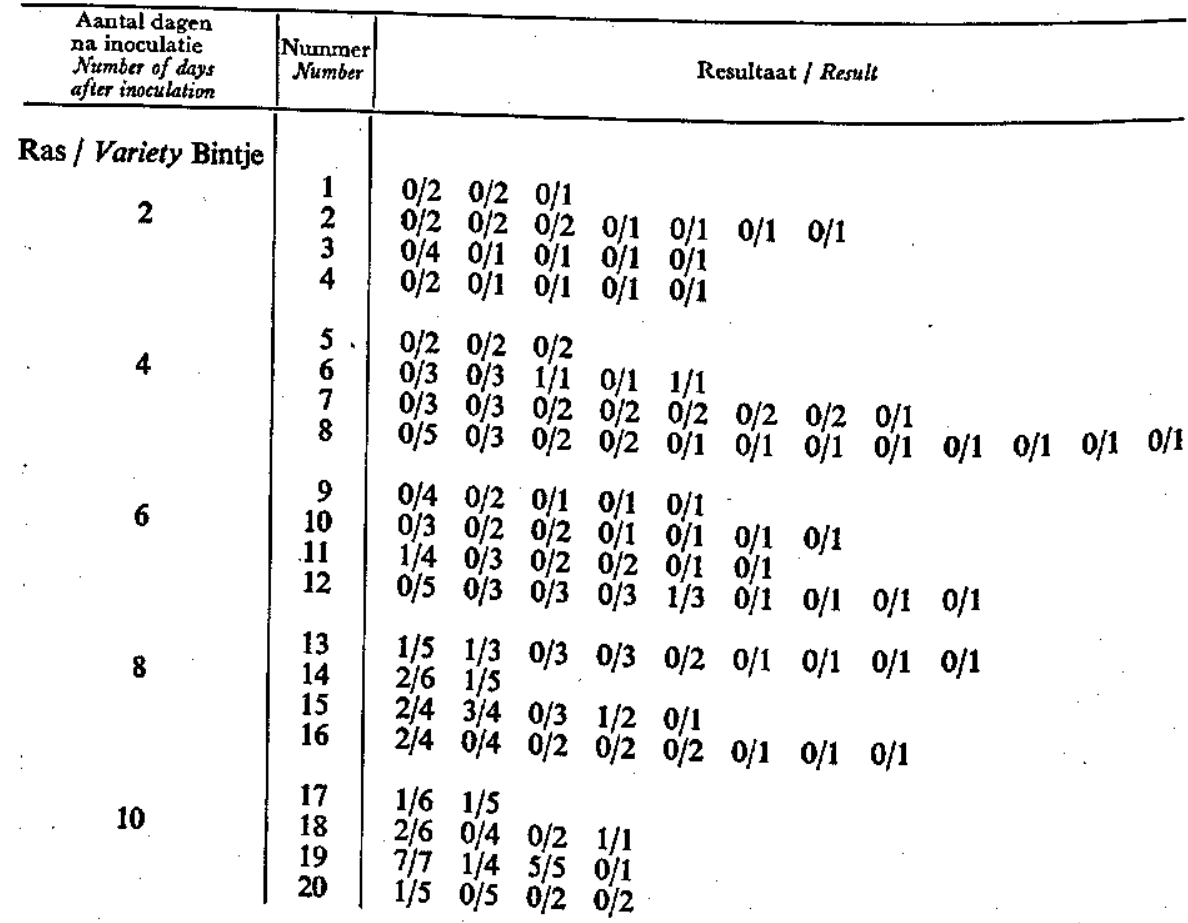




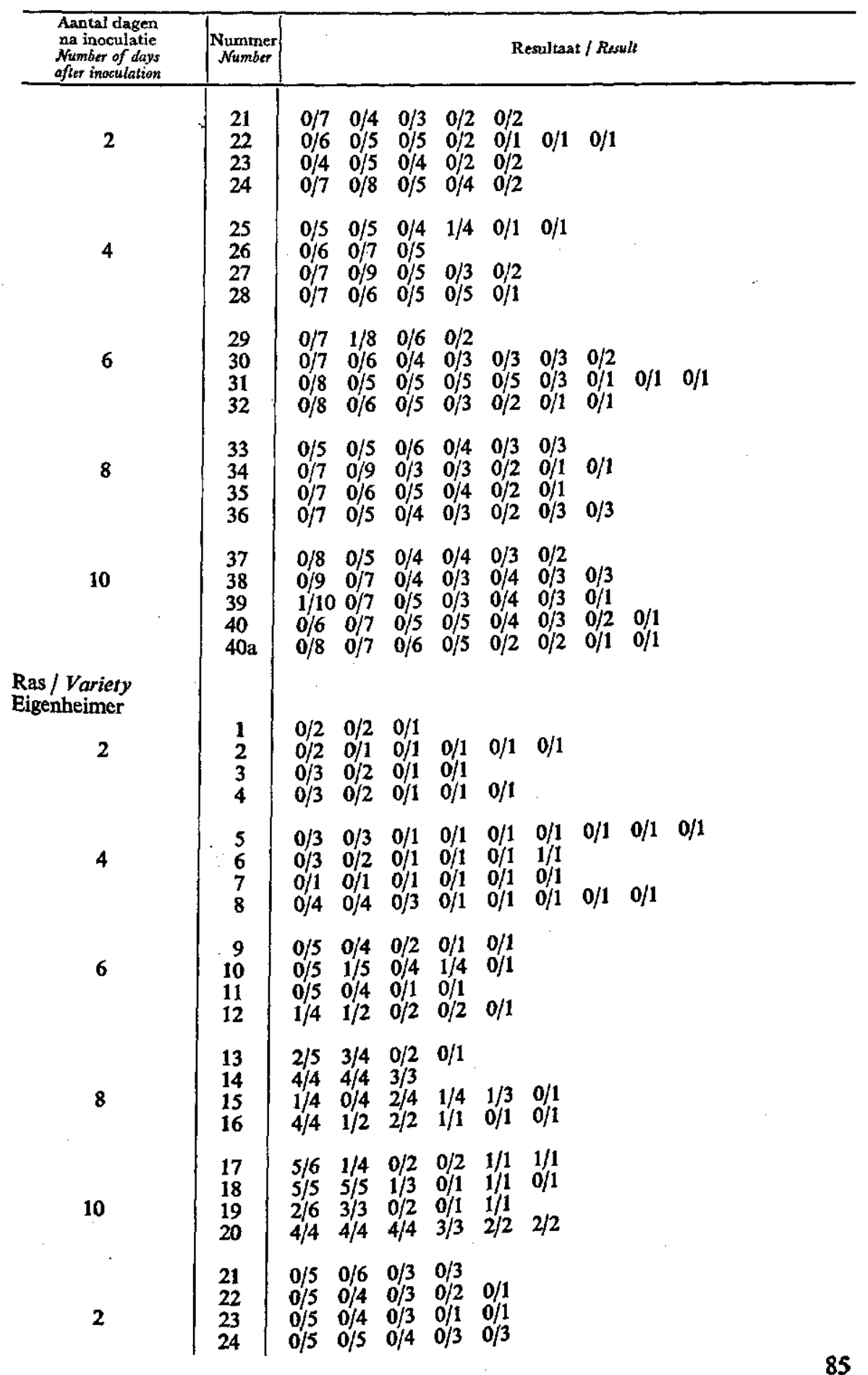




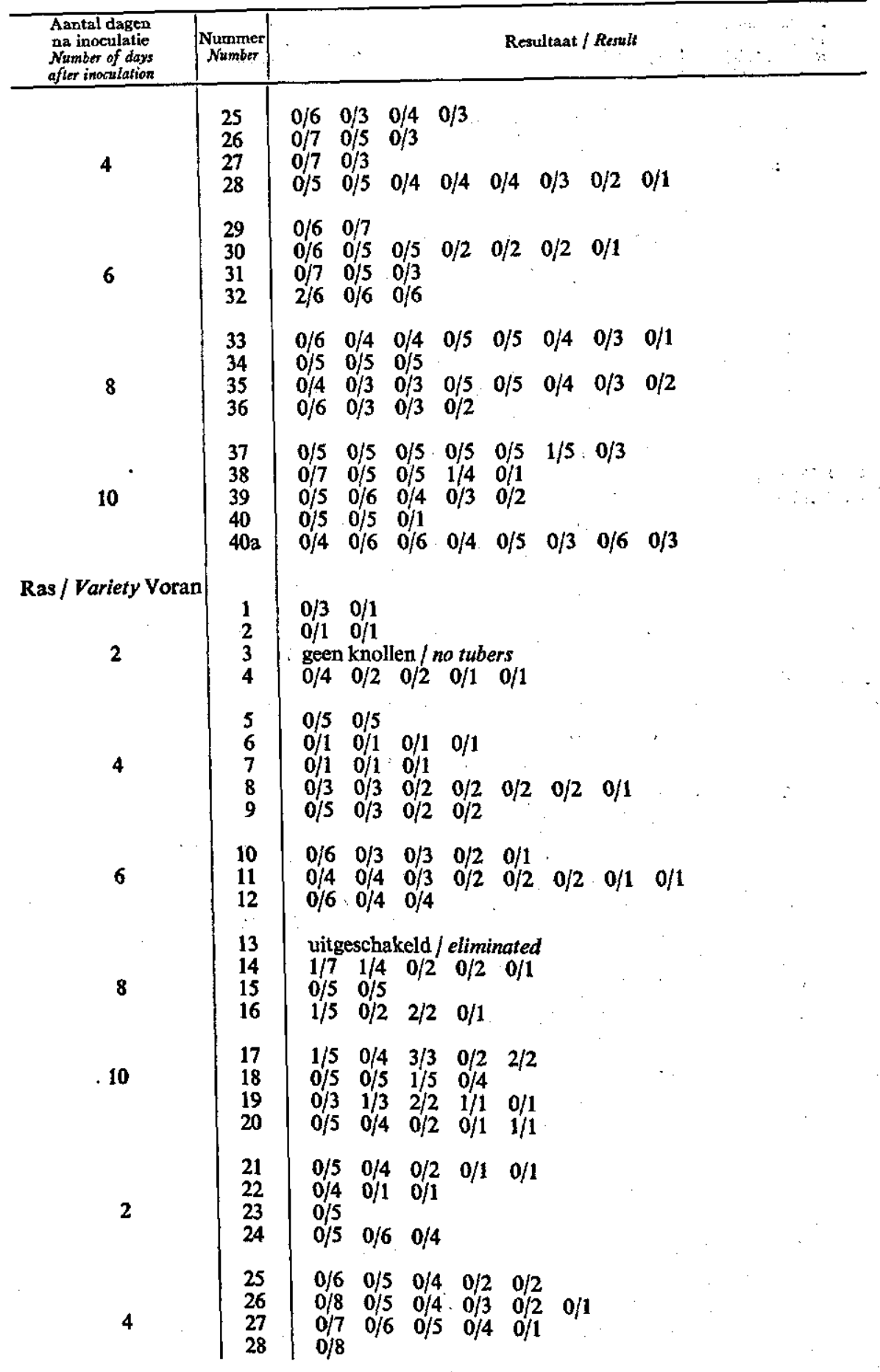




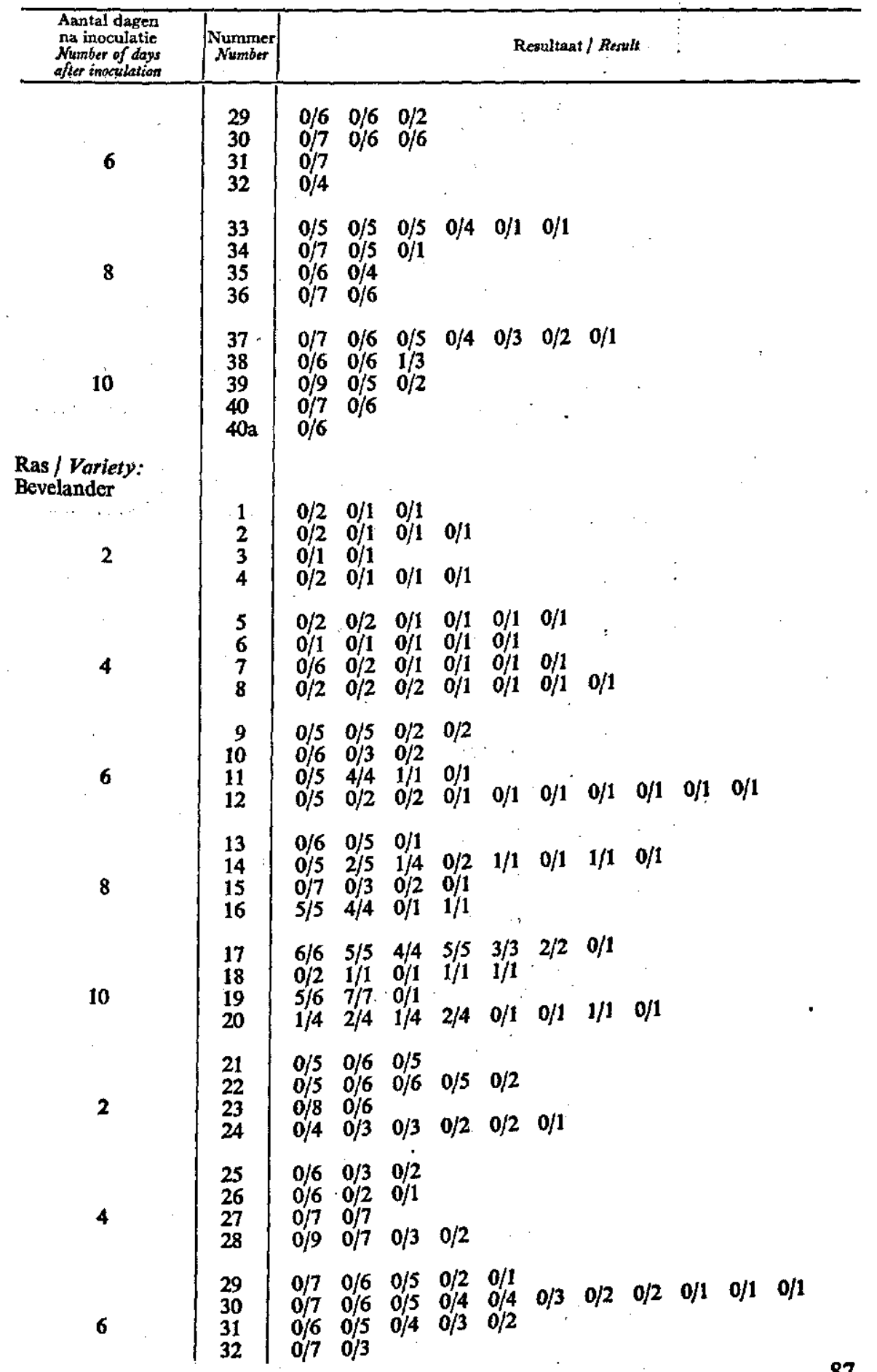




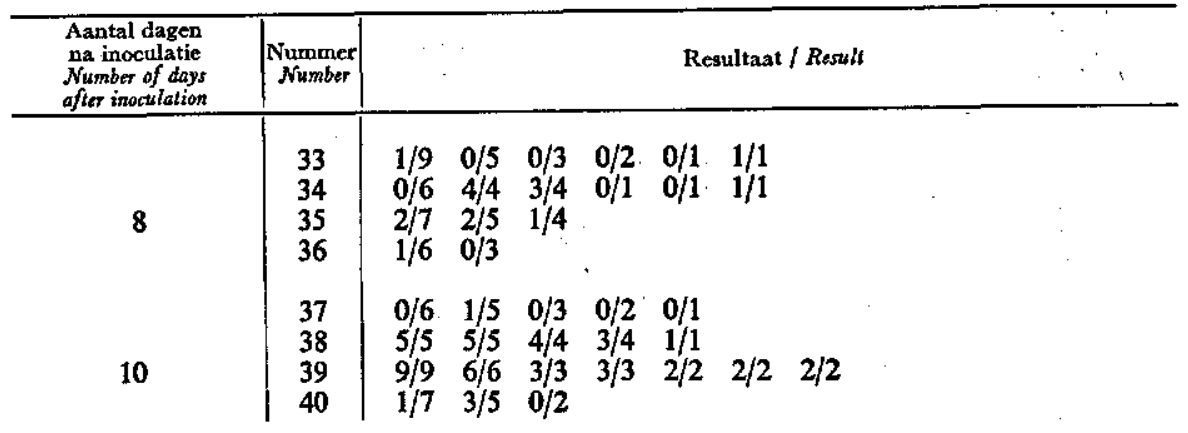

Prokf 3.3.5.2. Het transport van het aardappel X-virus van het geinoculeerde blad naar de knollen bij verschillende aardappelrassen.

Experiment 3.3.5.2. The translocation of potato virus $X$ from the inoculated leaf to the tubers in different potato varieties.

De knollen zijn gepoot op 1 september 1955. De inoculatie vond plaats op 12 oktober. De gegevens van de proef zijn op dezelfde wijze weergegeven als in proef 3.3.5.1.

The tubers were planted 1 September 1955. The plants were inoculated 12 October. The data of the experiment are given in the same way as in experiment 3.3.5.1.

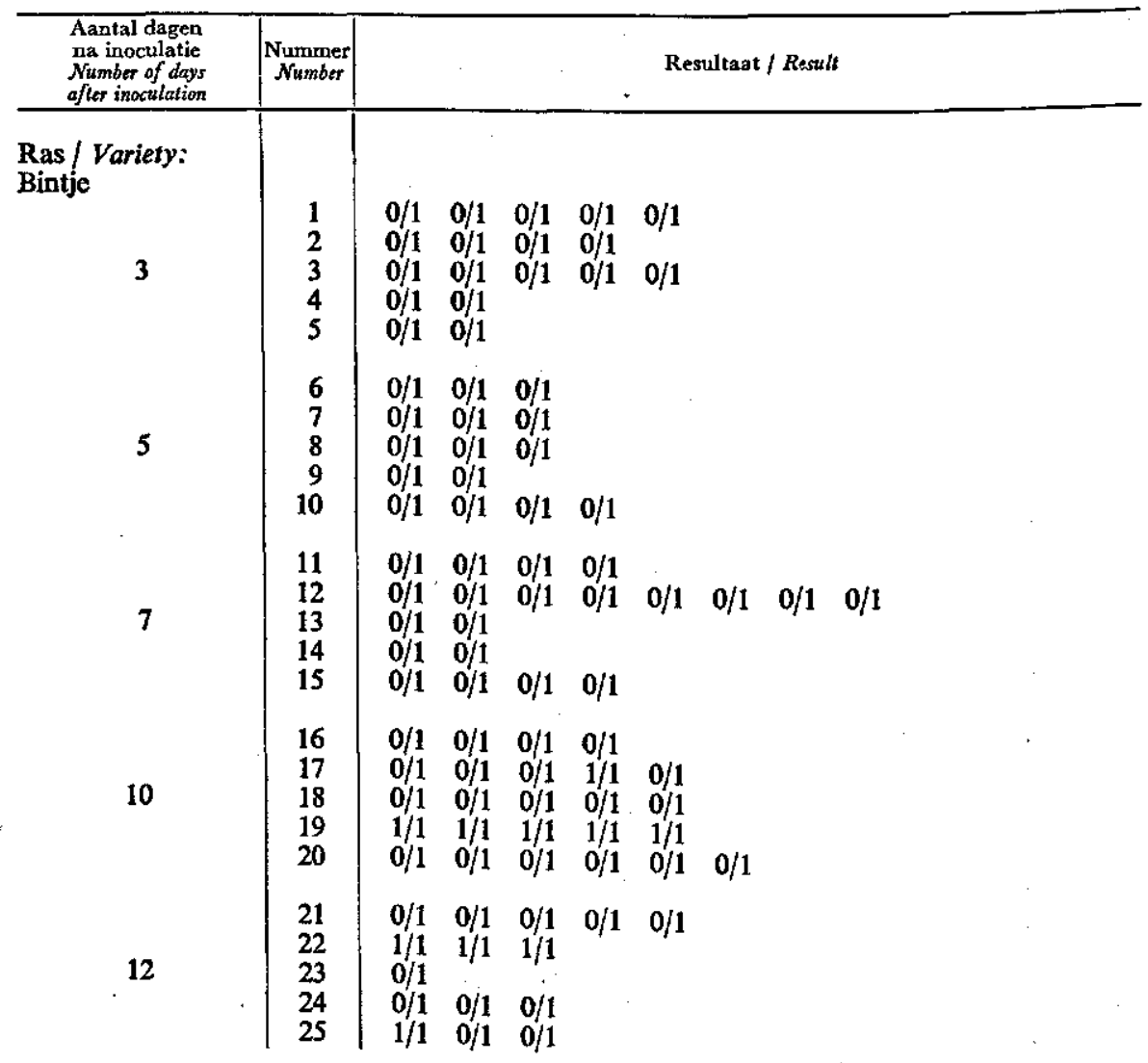




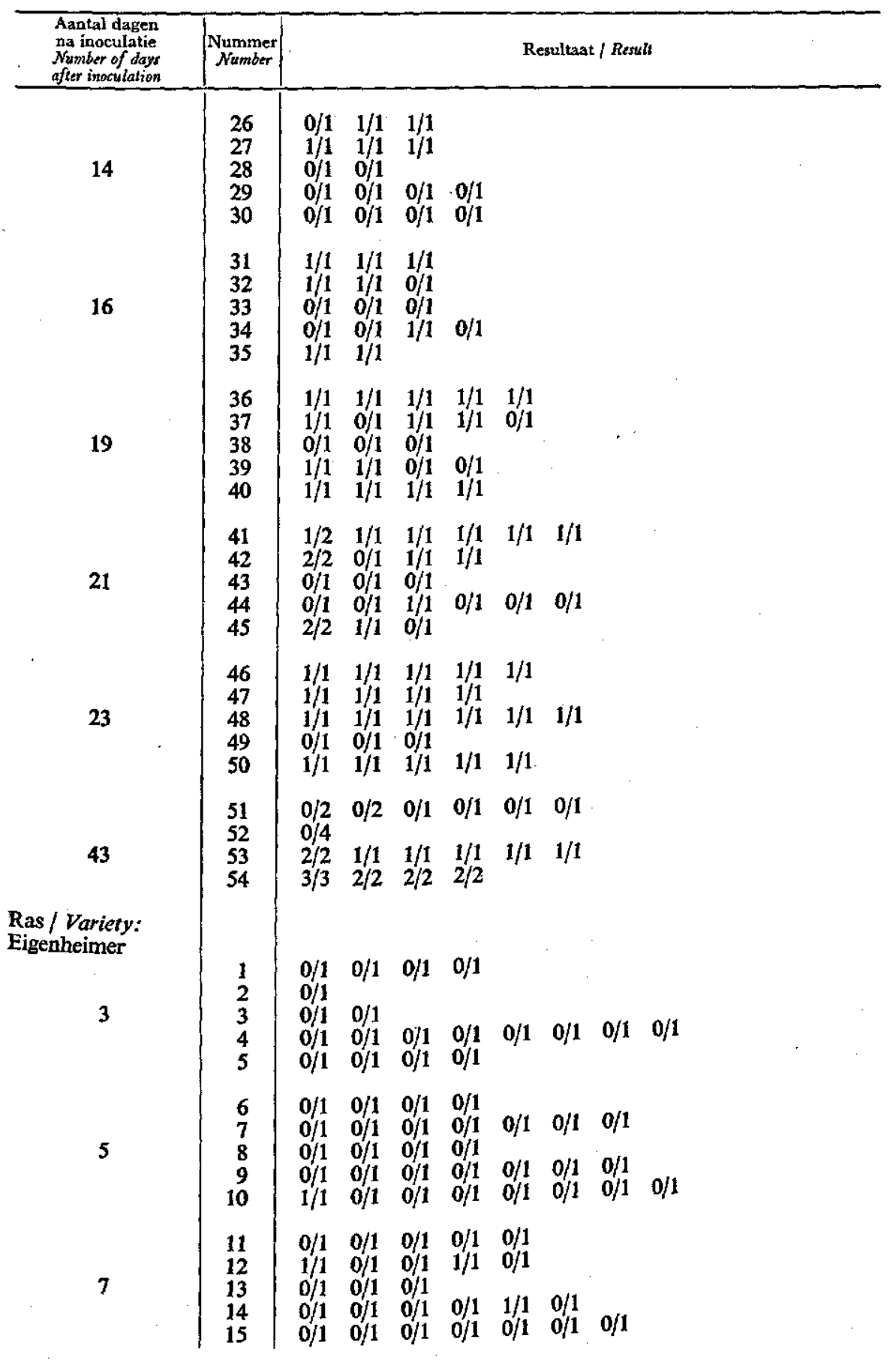




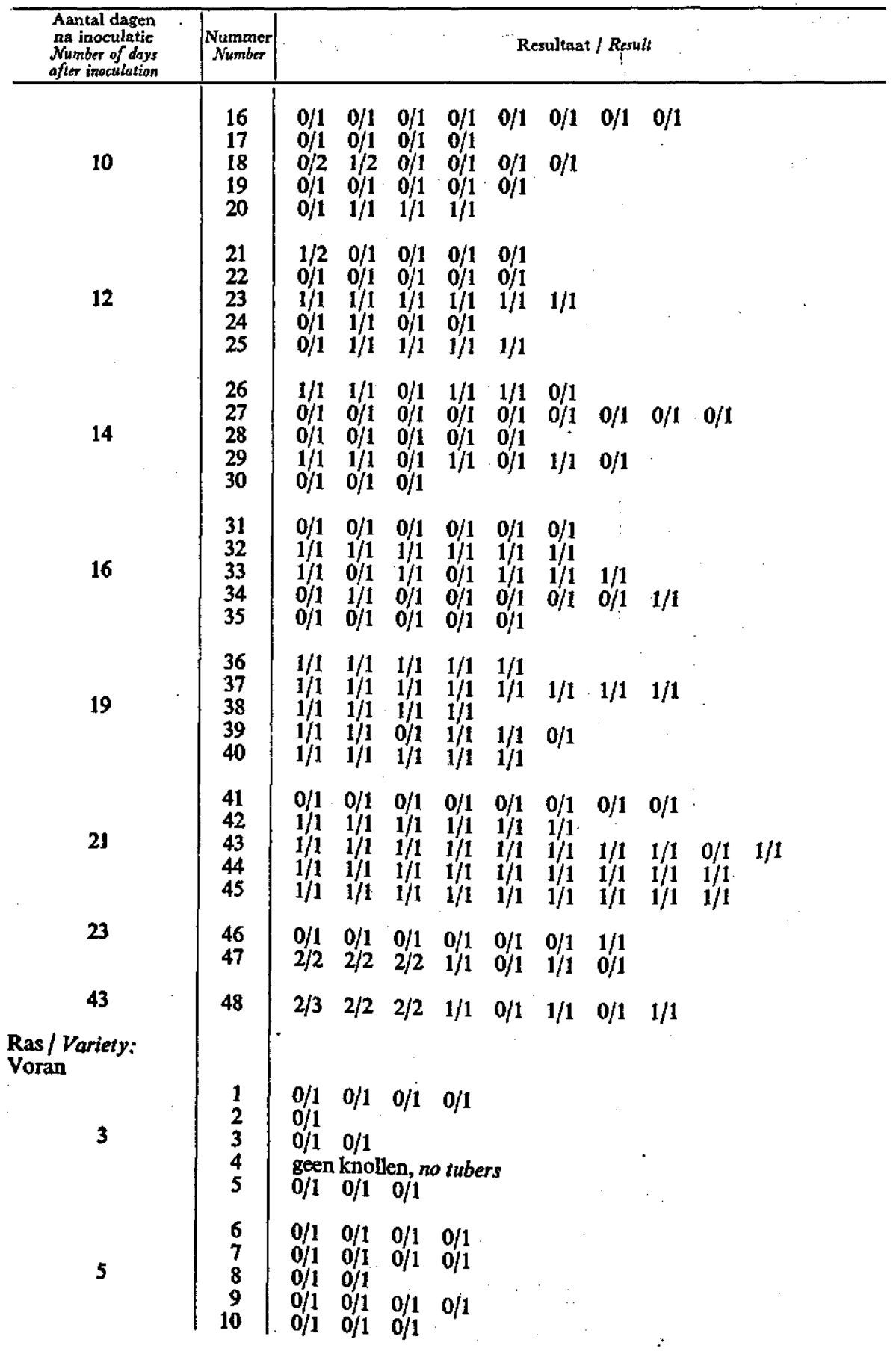




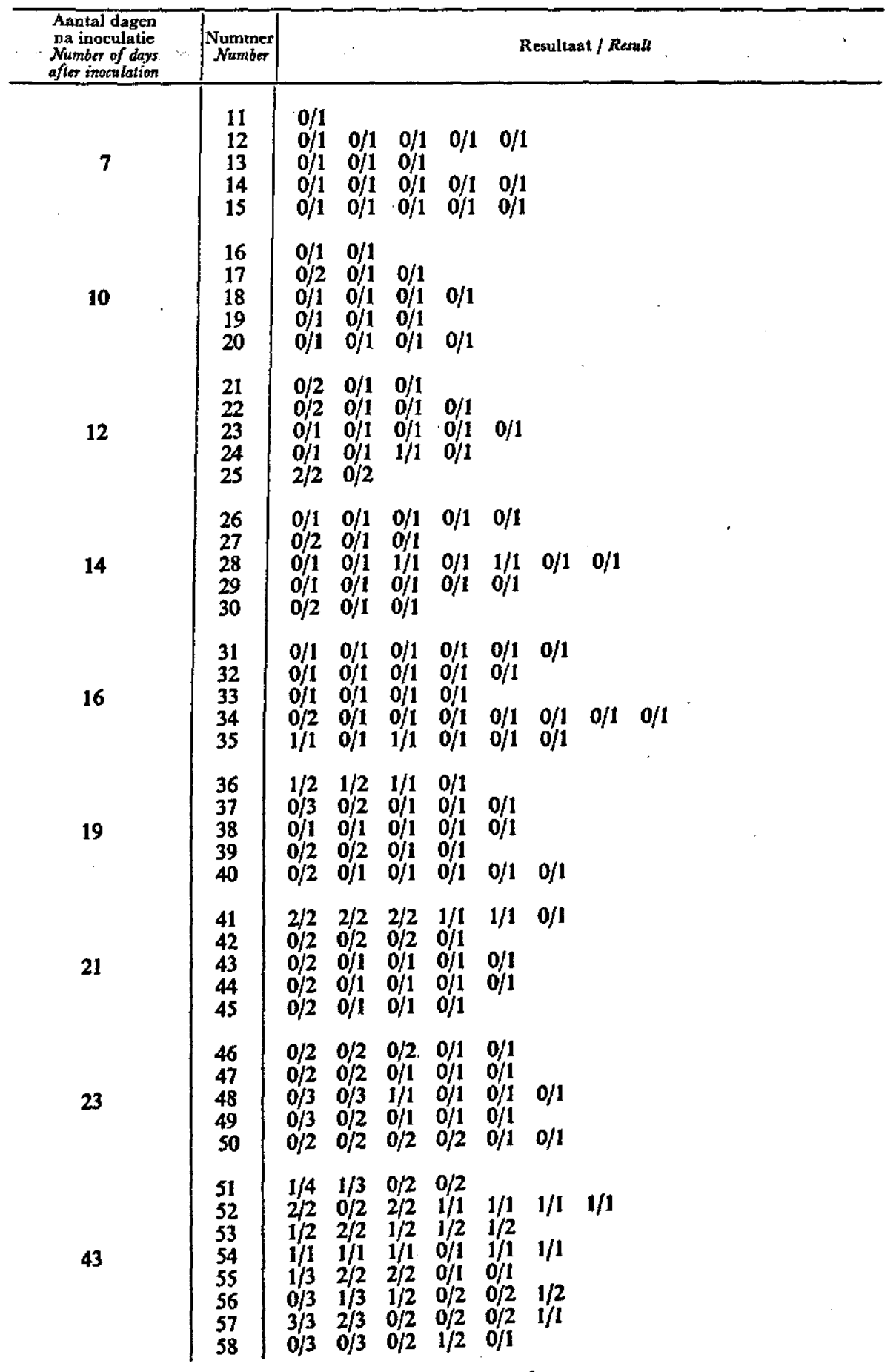




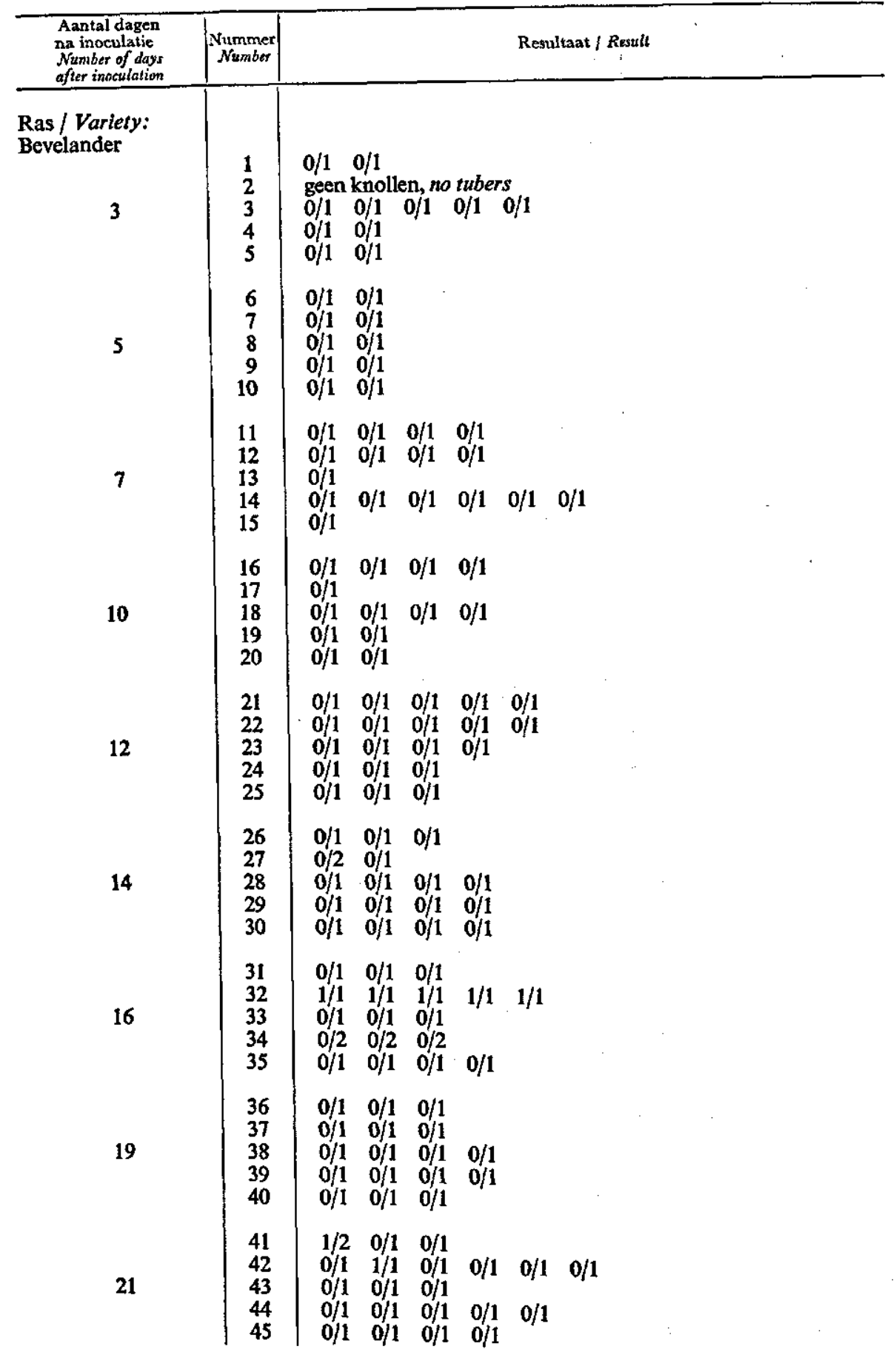




\begin{tabular}{c|c|cccccc}
\hline $\begin{array}{c}\text { Aantal dagen } \\
\text { na inculatie } \\
\begin{array}{c}\text { Number of days } \\
\text { afier inoculation }\end{array}\end{array}$ & $\begin{array}{c}\text { Nummer } \\
\text { Number }\end{array}$ & & & & & & Resultaat / Resslt \\
\hline & 46 & $1 / 1$ & $1 / 1$ & $0 / 1$ & $0 / 1$ & $0 / 1$ & $1 / 1$ \\
& 47 & $0 / 2$ & $1 / 1$ & $0 / 1$ & $0 / 1$ & & \\
23 & 48 & $0 / 2$ & $0 / 1$ & $0 / 1$ & $0 / 1$ & $0 / 1$ & $0 / 1$ \\
& 49 & $0 / 3$ & $0 / 3$ & & & &
\end{tabular}

Proer 4.2. De besmetting van de knollen van het aardappelras Bintje na inoculatie in verschillende groeistadia.

Experiment 4.2. The infection of the tubers of the potato variety Bintie after inoculation in different stages of their development. De knollen zijn gepoot 26 juli 1956. De vier series A, B, C en D zijn op de in de tabel ge-
geven data geinoculeerd. Een volgroeid blad in de top van elke plant werd geinoculeerd. Het rooien van telkens vijf planten vond plaats $5,10,15$ en 20 dagen na iedere inoculatie. De resultaten zijn op dezelfde wijze weergegeven als in proef 3.3.5.1.

The tubers were planted 26 July 1956. The four series $A, B$, Cant was inoculated. Harvesting data given in the table. One full-grown leaf in the top of each placulation. The results are given of five plants was performed $5,10,15$ and

in the same way as in experiment 3.3.5.1.

Serie A. Geïnoculeerd op 3 september 1946.

Series $A$. Inoculated on 3 September 1956.

\begin{tabular}{|c|c|c|}
\hline $\begin{array}{l}\text { Geoogst na } \\
\text { Harvested after }\end{array}$ & Nummer & Resultaat / Result \\
\hline 5 dagen / days & $\begin{array}{l}1 \\
2 \\
3 \\
4 \\
5\end{array}$ & 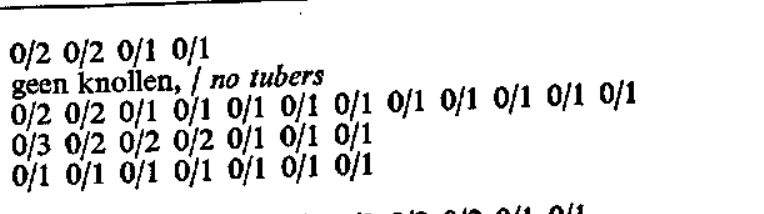 \\
\hline 10 dagen / days & $\begin{array}{r}6 \\
7 \\
8 \\
9 \\
10\end{array}$ & 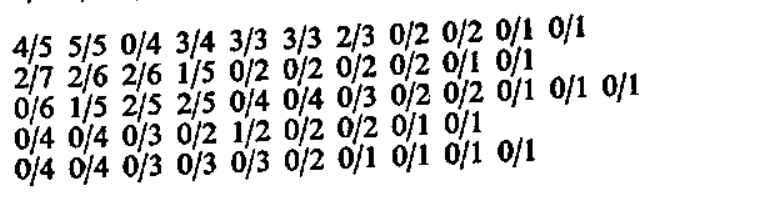 \\
\hline 15 dagen / days & $\begin{array}{l}11 \\
12 \\
13 \\
14 \\
15\end{array}$ & 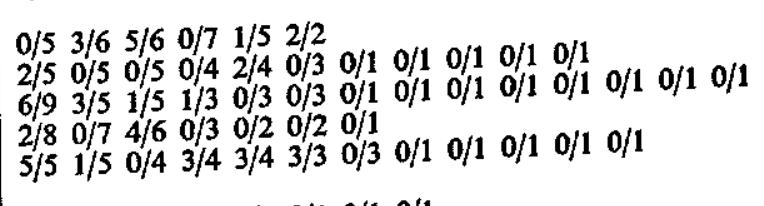 \\
\hline 20 dagen / days & $\begin{array}{l}16 \\
17 \\
18 \\
19 \\
20\end{array}$ & 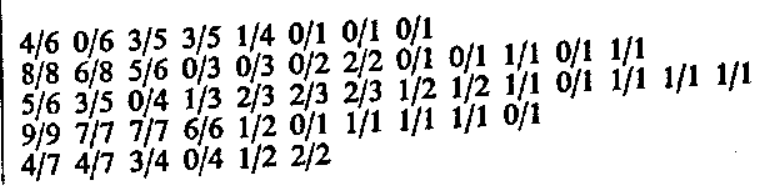 \\
\hline
\end{tabular}

Serie B. Geïnoculeerd op 10 september 1956.

Series $B$. Inoculated on 10 September 1956.

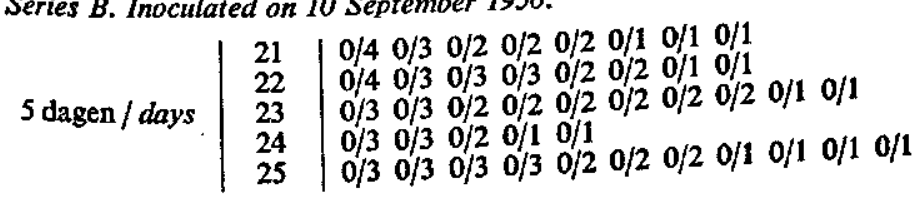




\begin{tabular}{|c|c|c|}
\hline $\begin{array}{l}\text { Geoogst na } \\
\text { Harvested affer }\end{array}$ & $\mid \begin{array}{c}\text { Nummer } \\
\text { Number }\end{array}$ & Resultaat / Resull \\
\hline 10 dagen / days & $\begin{array}{l}26 \\
27 \\
28 \\
29 \\
30\end{array}$ & 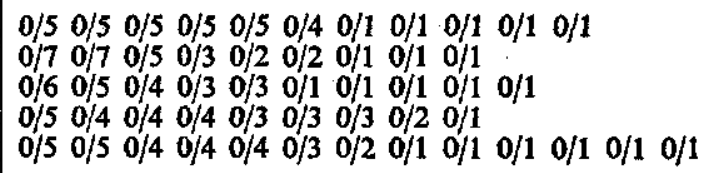 \\
\hline 15 dagen / days & $\begin{array}{l}31 \\
32 \\
33 \\
34 \\
35\end{array}$ & 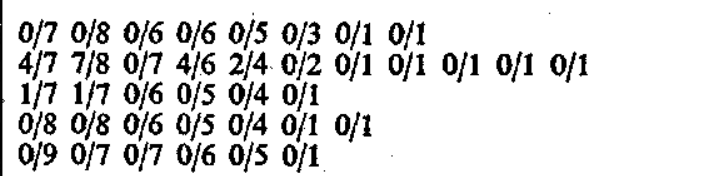 \\
\hline 20 dagen / days & $\begin{array}{l}36 \\
37 \\
38 \\
39 \\
40\end{array}$ & 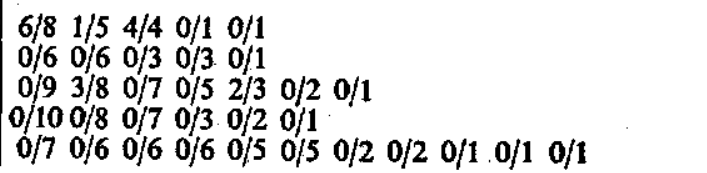 \\
\hline
\end{tabular}

Serie C. Geinoculeerd op 17 september 1956.

Series C. Inoculated on 17 September 1956

\begin{tabular}{|c|c|c|}
\hline 5 dagen / days & $\begin{array}{l}41 \\
42 \\
43 \\
44 \\
45\end{array}$ & 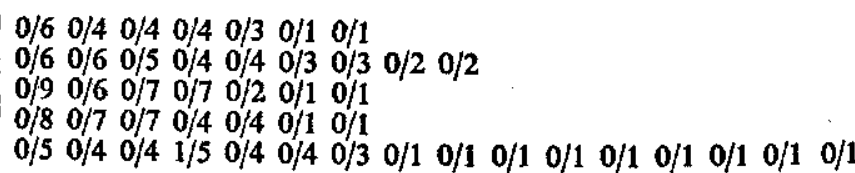 \\
\hline 10 dagen / days & $\begin{array}{l}46 \\
47 \\
48 \\
49 \\
50\end{array}$ & 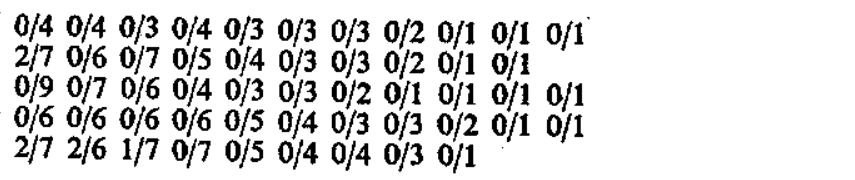 \\
\hline 15 dagen / days & $\begin{array}{l}51 \\
52 \\
53 \\
54 \\
55\end{array}$ & 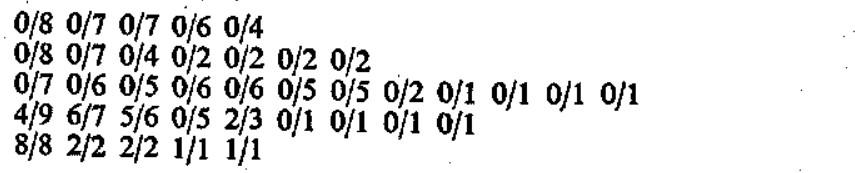 \\
\hline 20 dagen / days & $\begin{array}{l}56 \\
57 \\
58 \\
59\end{array}$ & 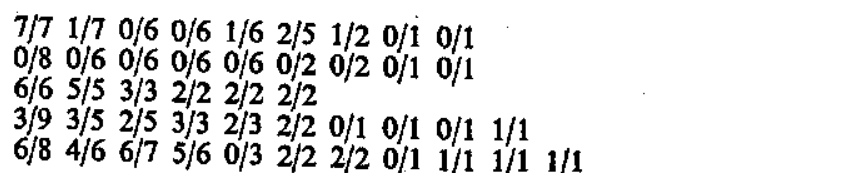 \\
\hline
\end{tabular}

Serie D. Geinoculeerd op 24 september 1956.

Series D. Inoculated on 24 September 1956.

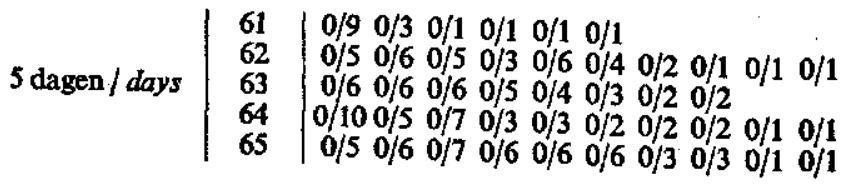




\begin{tabular}{|c|c|c|}
\hline $\begin{array}{l}\text { Geoogst na } \\
\text { Harvested affer }\end{array}$ & $\begin{array}{c}\text { Nummer } \\
\text { Number }\end{array}$ & Resultaat / Result \\
\hline 10 dagen / days & $\begin{array}{l}66 \\
67 \\
68 \\
69 \\
70\end{array}$ & 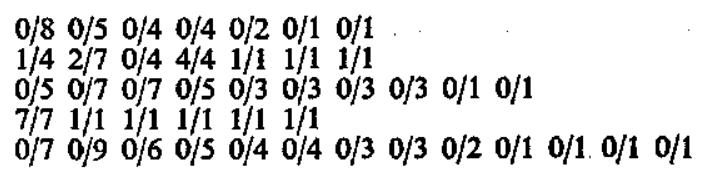 \\
\hline 15 dagen / days & $\begin{array}{l}71 \\
72 \\
73 \\
74 \\
75\end{array}$ & 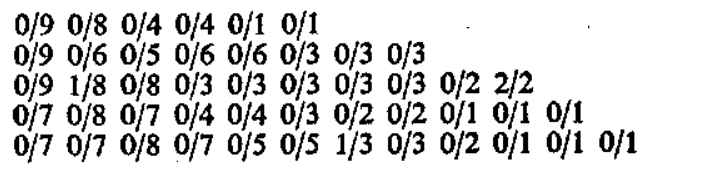 \\
\hline 20 dagen / days & $\begin{array}{l}76 \\
77 \\
78 \\
79 \\
80\end{array}$ & 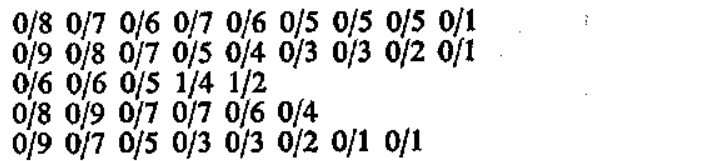 \\
\hline
\end{tabular}




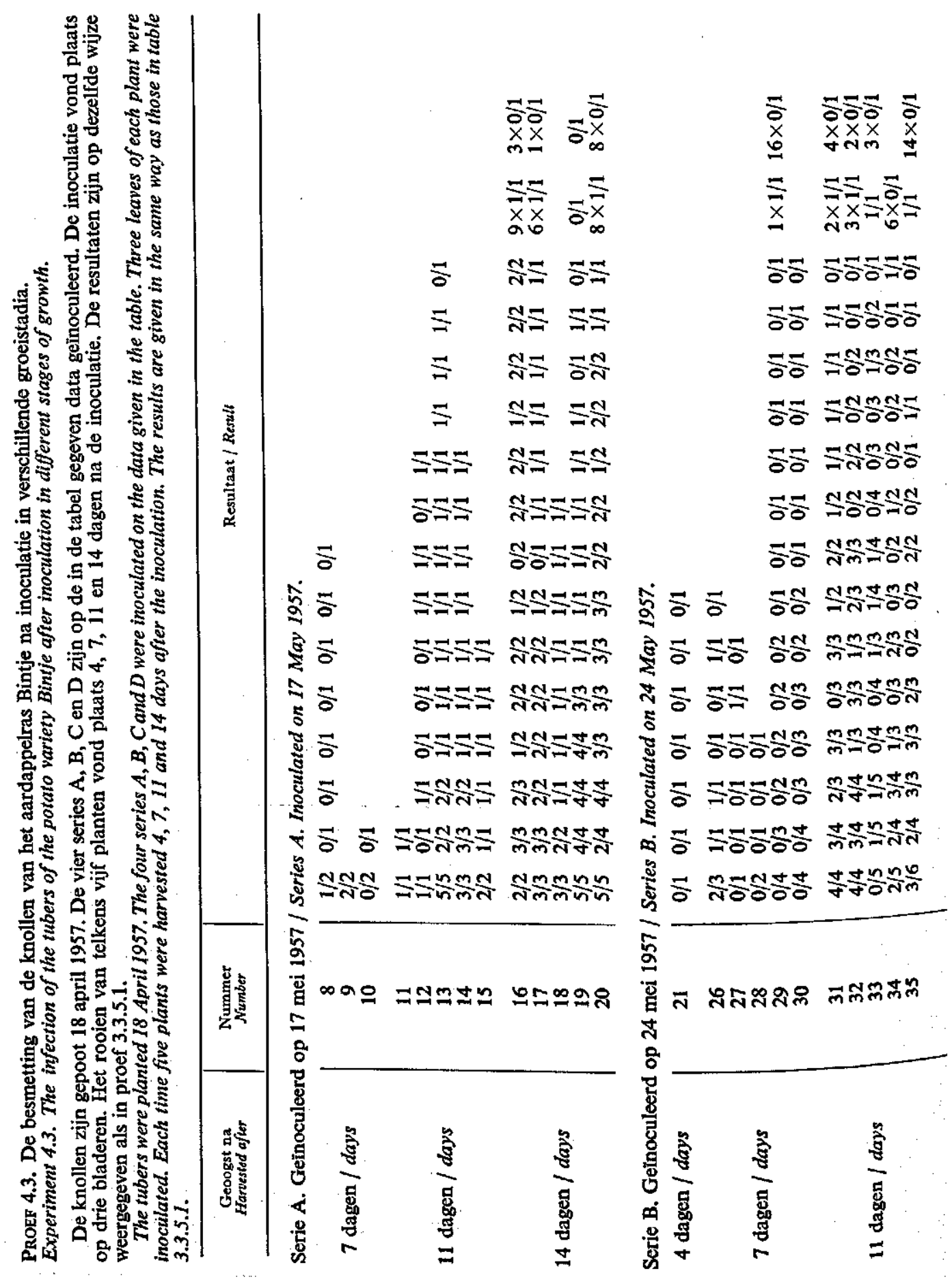




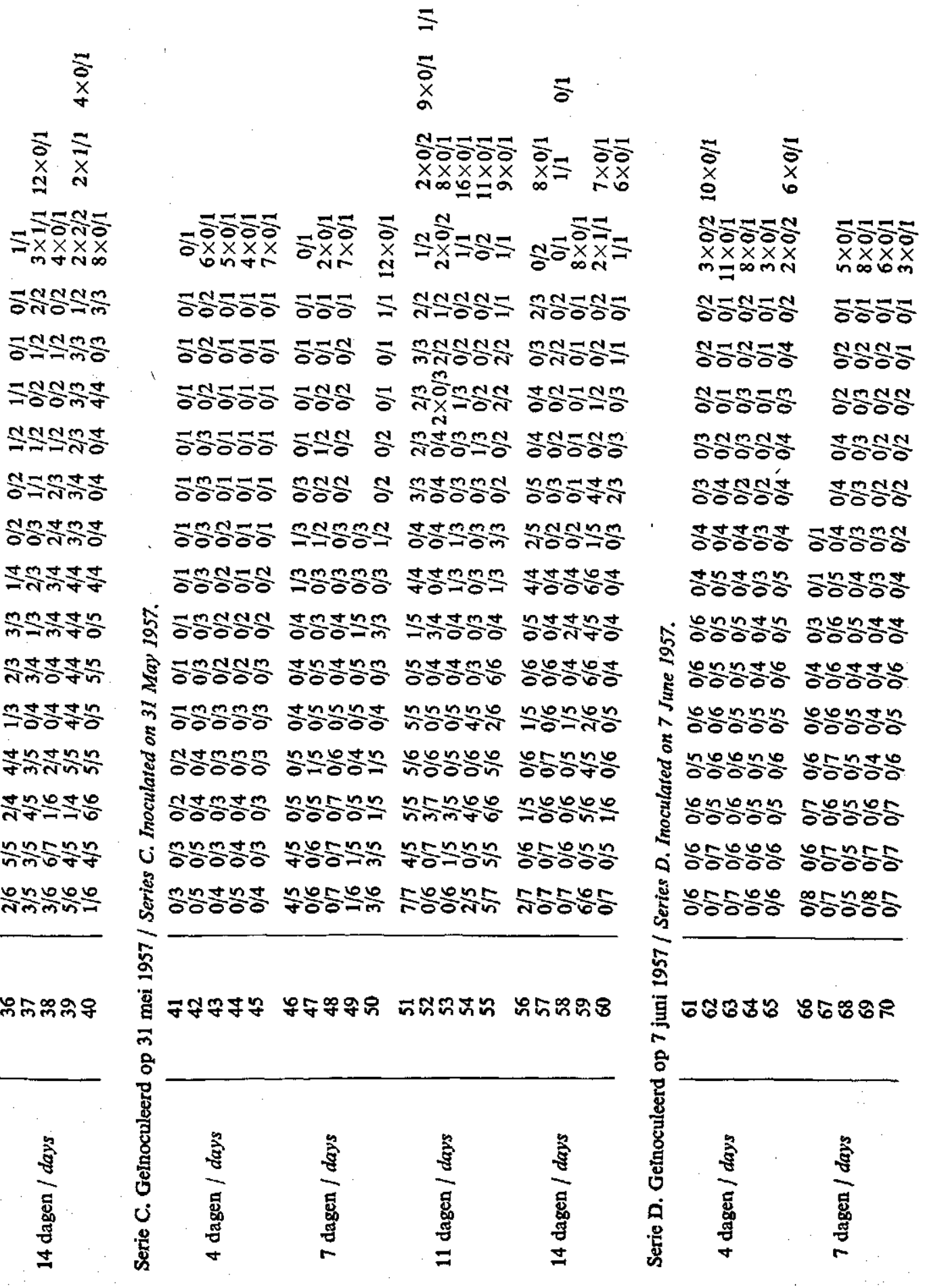




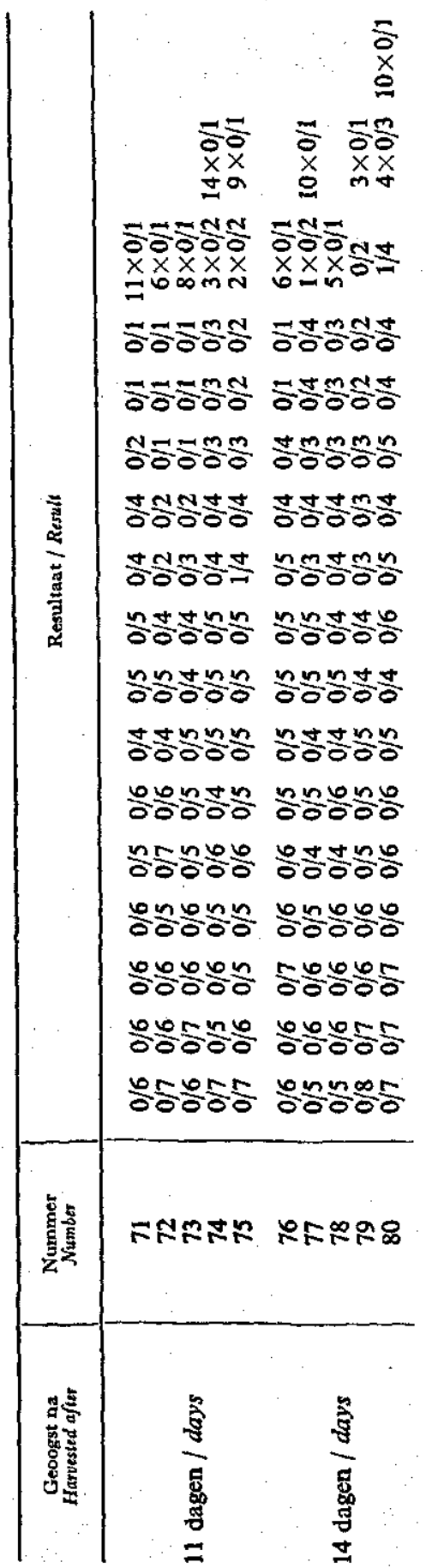

